\title{
Syntheses, Structures, and Reactivity of Divalent Germanium and Tin Compounds Containing a Diketiminato Ligand
}

\author{
Dissertation \\ zur Erlangung des Doktorgrades \\ der Mathematisch-Naturwissenschaftlichen Fakultäten \\ der Georg-August-Universität zu Göttingen \\ vorgelegt von \\ Diplom-Chemiker \\ Yuqiang Ding \\ aus Fangcheng, Henan \\ (CHINA)
}

Göttingen 2002 
D7

Referent:

Prof. H. W. Roesky

Korreferent:

Prof. F. Meyer

Tag der mündlichen Prüfung:

20. 06. 2002 


\section{Acknowledgment}

The work described in this doctoral dissertation has been carried out under the guidance and supervision of Professor Dr. Dr. h. c. mult H. W. Roesky at the Institut für Anorganische Chemie der Georg-August-Universität in Göttingen between January 1999 and June 2002.

I am sincerely grateful to

\section{Professor Dr. Dr. h. c. mult. H. W. Roesky}

for his constant guidance, motivation, suggestions, and discussion throughout this work. I also thank him for the personal kindness and care during my stay in Göttingen.

I thank Mr. Hans-Georg Schmidt, Dr. Mathias Noltemeyer, Dr. Isabel Usón, and Mr. Qinjun Ma for their help in the X-ray crystal structure determinations and their friendship. I thank Mr.Wolfgang Zolke, Mr. Ralf Schöne, and Dr. Gernot Elter for their help in the NMR measurements. I also thank Dr. Dieter Böhler, Mr. Thomas Schuchardt and Mrs. Anke Rehbein (Mass spectral measurements), Mr. Jürgen Schimkowiak, Mr. Martin Schlote and the staff of the Analytical Laboratories for their full support during my research work.

I would like to express my thanks to Dr. Haijun Hao, Dr. Guangcai Bai, Dr. Cunming Cui for collaborative work. I thank Mr. Carsten Ackerhans, Mr. Hans-Hürgen Ahn, Dr. Sonali Bhandari, Mr. Torsten Blunck, Mr. Jianfang Chai, Mr. Michael Gorol, Mr. Voitech Jancik, Mr. Jörg Janssen, Mr. Holger Hohmeister, Mr. Peter Lobinger, Mr. Dante Neculai, Mrs. Mirela Neculai, Ms. Ying Peng, Dr. Junfeng Rong, Dr. Grigori Nikiforov, Mr. Andreas

Stasch, Mr. Markus Schiefer, Mr. Shravan Kumar Srisailam, Ms. Wei Wie, Mr.Hongping Zhu, and Ms. Kerstin Most and many others for providing a friendly work atmosphere.

The help rendered by Dr. Michael Witt during writing this thesis is gratefully acknowledged. 


\section{Abbreviations}

\begin{tabular}{|c|c|}
\hline $\mathrm{Ar}$ & aryl \\
\hline av. & average \\
\hline $\mathrm{Br}$ & broad \\
\hline$n \mathrm{Bu}$ & $n$-butyl \\
\hline${ }^{\circ} \mathrm{C}$ & degree Celsius \\
\hline $\mathrm{Cp}$ & cyclopentadienyl \\
\hline $\mathrm{Cp}^{*}$ & pentamethylcyclopentadienyl \\
\hline $\mathrm{Cy}$ & cyclohexyl \\
\hline $\mathrm{D}$ & day(s), doublet \\
\hline dec. & decomposition \\
\hline DME & 1,2-dimethoxyethane \\
\hline$\delta$ & chemical shift (ppm) \\
\hline EI & electron impact ionization \\
\hline $\mathrm{Et}$ & ethyl \\
\hline Equiv (s) & equivalent(s) \\
\hline G & $\operatorname{gram}(\mathrm{s})$ \\
\hline $\mathrm{H}$ & hour(s) \\
\hline $\mathrm{Hz}$ & Hertz \\
\hline IR & infrared \\
\hline$J$ & coupling constant \\
\hline K & Kelvin \\
\hline$\lambda$ & wavelength \\
\hline M & metal \\
\hline $\mathrm{M}^{+}$ & molecular ion \\
\hline M & multiplet \\
\hline $\mathrm{Me}$ & methyl \\
\hline $\mathrm{Mg}$ & milligram(s) \\
\hline Min & minute(s) \\
\hline
\end{tabular}


$\mathrm{mL}$

Mmol

MS

$m / z$

$\mu$

NMR

$\mathrm{Ph}$

Ppm

$i \operatorname{Pr}$

$\mathrm{Pz}$

Q

r.t.

S

$\mathrm{t}$

tert

THF

TMS

$\mathrm{Tp}$

Z milliliter(s)

millimol(ar)

mass spectrometry

mass /charge

bridging

nuclear magnetic resonance

Phenyl

parts per million

iso-propyl

Pyrazolyl

quartet

room temperature

singlet

triplet

tertiary

tetrahydrofuran

tetramethylsilane

tris(pyrazolyl)hydroborato

number of molecules in the unit cell 


\section{TABLE OF CONTENTS}

\section{INTRODUCTION} 1

1.1. Halides of Germanium(II) and Tin(II) ........................................................ 1

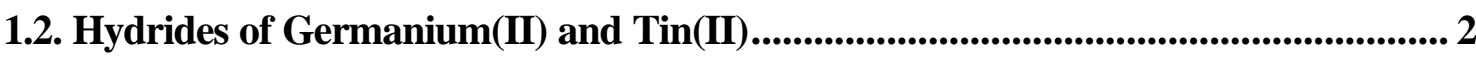

1.3. Compounds Involving Multiple Bonded Heavier Main Group Elements Bearing a Halide: Derivatives from the Divalent Halides........................................................... 2

1.4. Alkylated Germanium (II) Compounds .......................................................................... 3

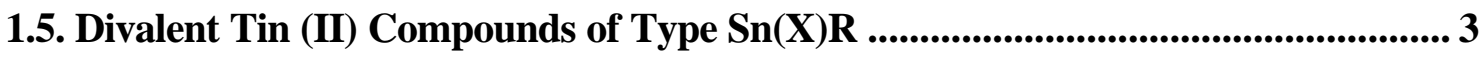

1.6. Scope and Aim of the Present Work ............................................................................. 4

2. RESULTS AND DISCUSSION ........................................................................

2.1. Monohalides of Divalent Germanium and Tin .......................................................... 5

2.1.1. Synthesis, Spectroscopic Studies and Structure of Divalent Germanium Chlorides 5

2.1.2. Synthesis, Spectroscopic Studies, and Structure of Divalent Tin Chloride (5)......... 7

2.2. Synthesis, Structure, and Reactivity of Ge (II) Fluorides ...................................9

2.2.1. Synthesis and Spectroscopic Studies of $\left[\mathrm{HC}(\mathrm{CMeNAr})_{2}\right] \mathrm{GeF}\left(\mathrm{Ar}=2,6-i \mathrm{Pr}_{2} \mathrm{C}_{6} \mathrm{H}_{3}\right.$

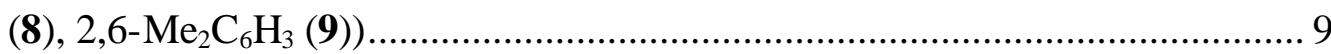

2.2.2. Single Crystal X-ray Structure Investigation of Compound 8 …......................... 10

2.2.3. Reactivity of $\mathbf{8}$ and the Formation of $\left[\left\{\mathrm{HC}(\mathrm{CMeNAr})_{2}\right\} \mathrm{Ge}(\mathrm{F}) \mathrm{NSiMe}_{3}\right](\mathrm{Ar}=2,6-$

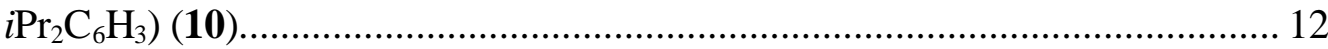

2.3. Synthesis, Structure, and Reactivity of Ge(II) Hydrides.................................... 13 
2.3.1. Synthesis and Spectroscopic Studies of $\left[\mathrm{HC}(\mathrm{CMeNAr})_{2}\right](\mathrm{GeH}) \mathrm{BH}_{3}(\mathrm{Ar}=2,6$ -

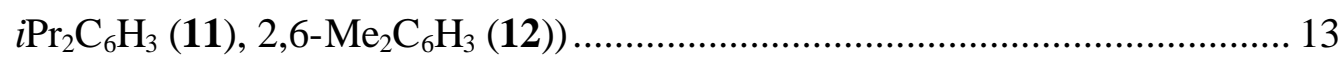

2.3.2. Single Crystal X-ray Structural Investigation of Compound 11 ........................... 14

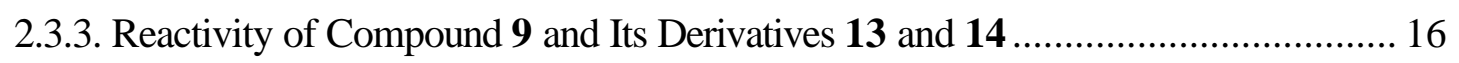

2.4. Synthesis, Structure, and Reactivity of Compounds Involving Multiple Bonded Heavier Main Group Elements Bearing a Halide: Derivatives from the Divalent

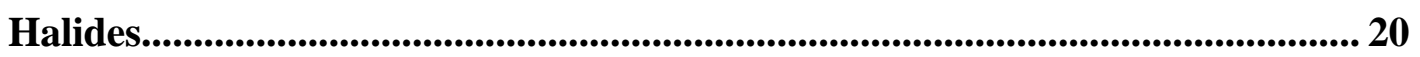

2.4.1. Synthesis and Structures of $\left[\left\{\mathrm{HC}(\mathrm{CMeNAr})_{2}\right\} \mathrm{Ge}(\mathrm{S}) \mathrm{X}\right]\left(\mathrm{Ar}=2,6-i \mathrm{Pr}_{2} \mathrm{C}_{6} \mathrm{H}_{3}, \mathrm{X}=\mathrm{Cl}\right.$

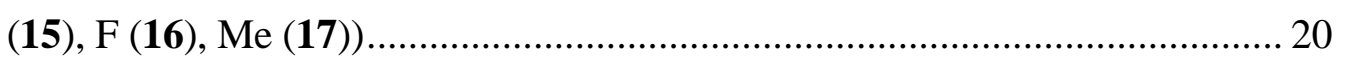

2.4.2. Synthesis and Structures of $\left[\left\{\mathrm{HC}(\mathrm{CMeNAr})_{2}\right\} \mathrm{Ge}(\mathrm{Se}) \mathrm{X}\right]\left(\mathrm{Ar}=2,6-i \mathrm{Pr}_{2} \mathrm{C}_{6} \mathrm{H}_{3}, \mathrm{X}=\right.$ $\mathrm{Cl}(\mathbf{1 8}), \mathrm{F}(\mathbf{1 9}), n \mathrm{Bu}(\mathbf{2 0}))$ 24

2.5. Synthesis, Structures, and Properties of $\left[\left\{\mathrm{HC}(\mathrm{CMeNAr})_{2}\right\} \mathrm{GeR}\right](\mathrm{Ar}=2,6-$

$\left.i \operatorname{Pr}_{2} \mathrm{C}_{6} \mathrm{H}_{3}, \mathrm{R}=\mathrm{Me}(21), n \mathrm{Bu}(22)\right)$ and the Resulting Derivatives $(23-25) \ldots . . . . .27$

2.6. Synthesis and Structures of Divalent Tin Compounds of Type $\operatorname{Sn}(X) R(26-29)$ 34

3.1. Summary 40

3.2. Outlook 45

4. EXPERIMENTAL SECTION 46

4.1. General procedures 46

4.2. Starting materials 47

4.3. Synthesis 47

4.3.1. Synthesis of $\left[\mathrm{HC}(\mathrm{CMeNAr})_{2}\right] \mathrm{Li}\left(\mathrm{OEt}_{2}\right)\left(\mathrm{Ar}=2,6-i \mathrm{Pr}_{2} \mathrm{C}_{6} \mathrm{H}_{3}\right)(\mathbf{1})$ 47 
4.3.2. Synthesis of $\left[\mathrm{HC}(\mathrm{CMeNAr})_{2}\right] \mathrm{Li}\left(\mathrm{OEt}_{2}\right)\left(\mathrm{Ar}=2,6-\mathrm{Me}_{2} \mathrm{C}_{6} \mathrm{H}_{3}\right)(2)$ 47

4.3.3. Synthesis of $\left[\left\{\mathrm{HC}(\mathrm{CMeNAr})_{2}\right\} \mathrm{GeCl}\right]\left(\mathrm{Ar}=2,6-i \operatorname{Pr}_{2} \mathrm{C}_{6} \mathrm{H}_{3}\right)(3) \ldots \ldots \ldots \ldots \ldots \ldots \ldots . . . . . . . . . . .48$

4.3.4. Synthesis of $\left[\left\{\mathrm{HC}(\mathrm{CMeNAr})_{2}\right\} \mathrm{GeCl}\right]\left(\mathrm{Ar}=2,6-\mathrm{Me}_{2} \mathrm{C}_{6} \mathrm{H}_{3}\right)(\mathbf{4}) \ldots \ldots \ldots \ldots \ldots \ldots \ldots . . . . . . . . . . .48$

4.3.5. Synthesis of $\left[\left\{\mathrm{HC}(\mathrm{CMeNAr})_{2}\right\} \mathrm{SnCl}\right]\left(\mathrm{Ar}=2,6-i \mathrm{Pr}_{2} \mathrm{C}_{6} \mathrm{H}_{3}\right)(\mathbf{5}) \ldots \ldots \ldots \ldots \ldots \ldots \ldots . . . . . . . . . . . .48$

4.3.6. Synthesis of $\left[\left\{\mathrm{HC}(\mathrm{CMeNAr})_{2}\right\} \mathrm{GeF}\right]\left(\mathrm{Ar}=2,6-i \mathrm{Pr}_{2} \mathrm{C}_{6} \mathrm{H}_{3}\right)(\mathbf{8}) \ldots \ldots \ldots \ldots \ldots \ldots \ldots . . . . . . . . . . . .49$

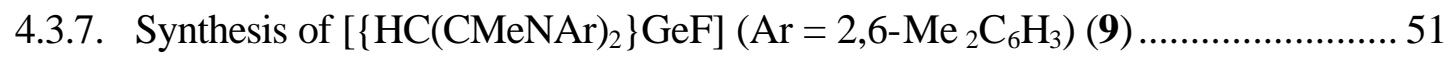

4.3.8. Synthesis of $\left[\left\{\mathrm{HC}(\mathrm{CMeNAr})_{2}\right\} \mathrm{Ge}(\mathrm{F}) \mathrm{NSiMe}_{3}\right]\left(\mathrm{Ar}=2,6-i \mathrm{Pr}_{2} \mathrm{C}_{6} \mathrm{H}_{3}\right)(\mathbf{1 0}) \ldots \ldots \ldots . . .51$

4.3.9. Synthesis of $\left[\left\{\mathrm{HC}(\mathrm{CMeNAr})_{2}\right\} \mathrm{GeH}\left(\mathrm{BH}_{3}\right)\right]\left(\mathrm{Ar}=2,6-i \mathrm{Pr}_{2} \mathrm{C}_{6} \mathrm{H}_{3}\right)(\mathbf{1 1}) \ldots \ldots \ldots \ldots . . . .51$

4.3.10. Synthesis of $\left[\left\{\mathrm{HC}(\mathrm{CMeNAr})_{2}\right\} \mathrm{Ge}(\mathrm{H}) \mathrm{BH}_{3}\right]\left(\mathrm{Ar}=2,6-\mathrm{Me}_{2} \mathrm{C}_{6} \mathrm{H}_{3}\right)(\mathbf{1 2}) \ldots \ldots \ldots . . .52$

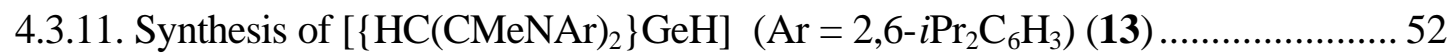

4.3.12. Synthesis of $\left[\left\{\mathrm{HC}\left(\mathrm{C}\left(\mathrm{CH}_{2}\right) \mathrm{NAr}\right) \mathrm{CMeNAr}\right\} \mathrm{Ge}(\mathrm{H}) \mathrm{BH}_{3}\right] \mathrm{Li}\left(\mathrm{Et}_{2} \mathrm{O}\right)_{3}(\mathrm{Ar}=2,6-$

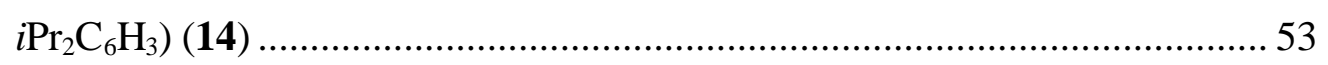

4.3.13. Synthesis of $\left[\left\{\mathrm{HC}(\mathrm{CMeNAr})_{2}\right\} \mathrm{Ge}(\mathrm{S}) \mathrm{Cl}\right]\left(\mathrm{Ar}=2,6-i \mathrm{Pr}_{2} \mathrm{C}_{6} \mathrm{H}_{3}\right)(\mathbf{1 5}) \ldots \ldots \ldots \ldots \ldots . . . . . . . .54$

4.3.14. Synthesis of $\left[\left\{\mathrm{HC}(\mathrm{CMeNAr})_{2}\right\} \mathrm{Ge}(\mathrm{S}) \mathrm{F}\right]\left(\mathrm{Ar}=2,6-i \mathrm{Pr}_{2} \mathrm{C}_{6} \mathrm{H}_{3}\right)(\mathbf{1 6}) \ldots \ldots \ldots \ldots \ldots . . . . . .54$

4.3.15. Synthesis of $\left[\left\{\mathrm{HC}(\mathrm{CMeNAr})_{2}\right\} \mathrm{Ge}(\mathrm{S}) \mathrm{Me}\right]\left(\mathrm{Ar}=2,6-i \mathrm{Pr}_{2} \mathrm{C}_{6} \mathrm{H}_{3}\right)(\mathbf{1 7}) \ldots \ldots \ldots \ldots \ldots . . . . . .55$

4.3.16. Synthesis of $\left[\left\{\mathrm{HC}(\mathrm{CMeNAr})_{2}\right\} \mathrm{Ge}(\mathrm{Se}) \mathrm{Cl}\right]\left(\mathrm{Ar}=2,6-i \mathrm{Pr}_{2} \mathrm{C}_{6} \mathrm{H}_{3}\right)(\mathbf{1 8}) \ldots \ldots \ldots \ldots \ldots . . . . . .55$

4.3.17. Synthesis of $\left[\left\{\mathrm{HC}(\mathrm{CMeNAr})_{2}\right\} \mathrm{Ge}(\mathrm{Se}) \mathrm{F}\right]\left(\mathrm{Ar}=2,6-i \mathrm{Pr}_{2} \mathrm{C}_{6} \mathrm{H}_{3}\right)(\mathbf{1 9}) \ldots \ldots \ldots \ldots \ldots . . . . . .56$

4.3.18. Synthesis of $\left[\left\{\mathrm{HC}(\mathrm{CMeNAr})_{2}\right\} \mathrm{Ge}(\mathrm{Se}) n \mathrm{Bu}\right]\left(\mathrm{Ar}=2,6-i \mathrm{Pr}_{2} \mathrm{C}_{6} \mathrm{H}_{3}\right)(\mathbf{2 0}) \ldots \ldots \ldots \ldots . . . .56$

4.3.19. Synthesis of $\left[\left\{\mathrm{HC}(\mathrm{CMeNAr})_{2}\right\} \mathrm{GeMe}\right]\left(\mathrm{Ar}=2,6-i \mathrm{Pr}_{2} \mathrm{C}_{6} \mathrm{H}_{3}\right)(\mathbf{2 1}) \ldots \ldots \ldots \ldots \ldots \ldots . . . . . . . . .57$

4.3.20. Synthesis of $\left[\left\{\mathrm{HC}(\mathrm{CMeNAr})_{2}\right\} \mathrm{Gen} \mathrm{Bu}\right]\left(\mathrm{Ar}=2,6-i \mathrm{Pr}_{2} \mathrm{C}_{6} \mathrm{H}_{3}\right)(\mathbf{2 2}) \ldots \ldots \ldots \ldots \ldots \ldots . . . . . . . . .57$

4.3.21. Synthesis of $\left[\left\{\mathrm{HC}(\mathrm{CMeNAr})_{2}\right\} \mathrm{Ge}(\mathrm{Se}) \mathrm{Me}\right]\left(\mathrm{Ar}=2,6-i \mathrm{Pr}_{2} \mathrm{C}_{6} \mathrm{H}_{3}\right)(\mathbf{2 3}) \ldots \ldots \ldots \ldots . . .58$

4.3.22. Synthesis of $\left[\left\{\mathrm{HC}\left(\mathrm{C}\left(\mathrm{CH}_{2}\right) \mathrm{NAr}\right) \mathrm{CMeNAr}\right\} \mathrm{Ge}(\mathrm{Me}) \mathrm{N}(\mathrm{H}) \mathrm{SiMe}_{3}\right](\mathrm{Ar}=2,6-$

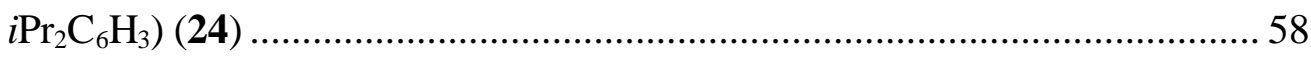

4.3.23. Synthesis of $\left[\left\{\mathrm{HC}(\mathrm{CMeNAr})_{2}\right\} \mathrm{GeMe}_{2} \mathrm{I}\right]\left(\mathrm{Ar}=2,6-i \mathrm{Pr}_{2} \mathrm{C}_{6} \mathrm{H}_{3}\right)(\mathbf{2 5}) \ldots \ldots \ldots \ldots \ldots . . . . . . . . .59$

4.3.24. Synthesis of $\left[\left\{\mathrm{HC}(\mathrm{CMeNAr})_{2}\right\}_{2} \mathrm{Sn}\right]\left(\mathrm{Ar}=2,6-i \mathrm{Pr}_{2} \mathrm{C}_{6} \mathrm{H}_{3}\right)(\mathbf{2 6}) \ldots \ldots \ldots \ldots \ldots \ldots \ldots \ldots . . . . . . . . . . .60$

4.3.25. Synthesis of $\left[\left\{\mathrm{HC}(\mathrm{CMeNAr})_{2}\right\} \mathrm{Sn} t \mathrm{Bu}\right]\left(\mathrm{Ar}=2,6-i \mathrm{Pr}_{2} \mathrm{C}_{6} \mathrm{H}_{3}\right)(27) \ldots \ldots \ldots \ldots \ldots \ldots . . . . . . . . . .60$

4.3.26. Synthesis of $\left[\left\{\mathrm{HC}(\mathrm{CMeNAr})_{2}\right\} \mathrm{SnOSO}_{2} \mathrm{CF}_{3}\right]\left(\mathrm{Ar}=2,6-i \mathrm{Pr}_{2} \mathrm{C}_{6} \mathrm{H}_{3}\right)(\mathbf{2 8}) \ldots \ldots \ldots \ldots . . .61$

4.3.27. Synthesis of $\left[\left\{\mathrm{HC}(\mathrm{CMeNAr})_{2}\right\} \mathrm{SnN}_{3}\right]\left(\mathrm{Ar}=2,6-i \mathrm{Pr}_{2} \mathrm{C}_{6} \mathrm{H}_{3}\right)(\mathbf{2 9}) \ldots \ldots \ldots \ldots \ldots \ldots \ldots . . . . . . . . . .61$ 
5. HANDLING AND DISPOSAL OF SOLVENTS AND RESIDUAL WASTES ... .62

6. CRYSTAL DATA AND REFINEMENT DETAILS........................................63

7. REFERENCES. .80 


\section{Introduction}

There is widespread interest in the chemistry of divalent derivatives of the heavier group 14 elements due to their carbene-like properties. Tremendous progress of the chemistry of germanium and tin in the +2 oxidation state, germylenes or stannylenes, was achieved during the past two decades. ${ }^{1}$ However, a large gap still exists in contrast to the chemistry in their +4 oxidation states because of the high reactivity and tendency to oligomerize or polymerize such species.

It was recognized that low valent group 14 compounds can be stabilized kinetically by sterically demanding ligands and/or thermodynamically by inter- and intramolecular coordination. ${ }^{2}$ Indeed, several nitrogen containing bulky ligands have been used to stabilize these compounds. Thus, a great number of divalent germanium and tin species have been prepared. Anionic chelating $\beta$-diketiminato ligands $\left[\mathrm{HC}(\mathrm{CRNR})_{2}\right]^{-}\left(\mathrm{R}=\mathrm{Me}, \mathrm{Ph} ; \mathrm{R}^{\prime}=\right.$ $\mathrm{SiMe}_{3}$, aryl), where steric flexibility is afforded by variation of the substituents on the ligand backbone, can be used as spectator ligands. Such ligands already have been employed in transition metal chemistry. ${ }^{3}$ Recently the coordination chemistry of these ligands with main group elements has drawn attention. ${ }^{4}$ We have prepared the first monomeric aluminum(I) compound $\left[\left\{\mathrm{HC}(\mathrm{CMeNAr})_{2}\right\} \mathrm{Al}\right]\left(\mathrm{Ar}=2,6-i \mathrm{Pr}_{2} \mathrm{C}_{6} \mathrm{H}_{3}\right)$ by taking advantage of such a ligand. ${ }^{5}$ They may be potentially useful to prepare divalent germanium and tin compounds. In the following part, some of the work which is related to the content of the present thesis will be discussed in detail.

\subsection{Halides of Germanium(II) and Tin(II)}

Halides of group 14 elements are important precursors for a variety of new reactions. Dihalogermylenes, $\mathrm{GeX}_{2}(\mathrm{X}=\mathrm{F}, \mathrm{Cl}, \mathrm{Br}$, and I), which are the first known divalent species, had been studied and reviewed as starting materials and intermediates in organogermanium chemistry in $1973 .^{6}$ The monohalide $\mathrm{Cp} * \mathrm{GeCl}$, the first example of the type RMX $(\mathrm{M}=\mathrm{Ge}$, $\mathrm{Sn} ; \mathrm{R}=$ organic group; $\mathrm{X}=$ halide), was prepared in $1983,{ }^{7}$ followed by the tin analogue $\mathrm{RSnCl}\left(\mathrm{R}=\mathrm{C}\left(\mathrm{SiMe}_{3}\right)_{2} \mathrm{C}_{5} \mathrm{H}_{4} \mathrm{~N}-2\right)$ in $1988 .^{8}$ Results showed the monohalides constitute an 
interesting class of compounds with regard to structure and bonding, and furthermore they can serve as useful precursors for the synthesis of new low valent compounds by nucleophilic substitution or reductive dehalogenation processes. ${ }^{6}$

The fluoro compounds are of interest and expected to have a different reactivity due to the strong electron with-drawing effect of fluorine compared to the other halides. ${ }^{9}$ Moreover, organometallic fluorides of the group 14 elements are important because of their industrial application, synthetic methodology, and theoretical implications. ${ }^{10}$ However, to the best of our knowledge, the known compounds involve group 14 elements preferentially in the +4 oxidation state. Only two dimeric Sn(II) fluorides were reported as stable molecules, ${ }^{11}$ and one Ge(II) fluoride, $\mathrm{PhGeF}$, was studied as a reactive intermediate. ${ }^{12}$ Therefore it was of interest to prepare stable Ge(II) fluorides.

\subsection{Hydrides of Germanium(II) and Tin(II)}

The hydrides of group 14 elements are important and their chemistry and applications are very rich. ${ }^{13}$ However, almost all such compounds reported to date involve the central element in the +4 oxidation state. Only one tin(II) hydride was recently reported as the first example of a divalent group 14 element hydride. ${ }^{14}$ Currently, there is a growing interest in Ge(IV) hydrides since the germanium hydrides have been neglected for a long ime compared to silicon and tin hydrides. ${ }^{15}$ This rapid development of the Ge(IV) chemistry encouraged chemists to synthesize Ge(II) hydrides.

\subsection{Compounds Involving Multiple Bonded Heavier Main Group Elements Bearing a Halide: Derivatives from the Divalent Halides}

Species containing multiple bonded heavier main group elements are important precursors for a variety of new reactions. Especially compounds with halides, where the halides can easily be replaced to synthesize a plethora of new compounds, are of great interest. Over the past few decades, double bonds between heavier main group elements had been considered to be unstable due to their weak $\pi$-bonds. ${ }^{16}$ However, in 1981 , compounds with $\mathrm{Si}=\mathrm{C},{ }^{17}$ 
$\mathrm{Si}=\mathrm{Si},{ }^{16}$ and $\mathrm{P}=\mathrm{P}^{18}$ bonds were prepared for the first time by taking advantage of the protection by bulky ligands. Since then, remarkable progress has been made in the chemistry of multiple bonded compounds of heavier main group elements. ${ }^{2 \mathrm{e}}$ In recent years, interest in the chemistry of double bonded species between heavier group 14 and 16 elements $\mathrm{M}=\mathrm{E}$ $(\mathrm{M}=\mathrm{Si}, \mathrm{Ge}, \mathrm{Sn} ; \mathrm{E}=\mathrm{S}, \mathrm{Se}, \mathrm{Te})$, analogues of ketones, has remarkably increased. ${ }^{2 \mathrm{e}, 19}$ Examples such as $\mathrm{Si}(\mathrm{E}=\mathrm{S}),{ }^{20} \mathrm{Ge}(\mathrm{E}=\mathrm{S}, \mathrm{Se}, \mathrm{Te}),{ }^{21}$ and $\mathrm{Sn}(\mathrm{E}=\mathrm{S}, \mathrm{Se}, \mathrm{Te})^{22}$ have been synthesized and structurally characterized. In contrast, the chemistry of compounds involving multiply bonded elements bearing halides was neglected, only one example was recently reported without structural investigation. ${ }^{23}$ It is of great interest to prepare the heavier chalcogen analogues of alkanoyl halide $\mathrm{M}(\mathrm{X})=\mathrm{E}$, as potentially important precursors for the synthesis of compounds containing double bonded heavier main group elements.

\subsection{Alkylated Germanium (II) Compounds}

Studies showed that compounds of divalent germanium bonded to small alkyl substituents (such as $\mathrm{Me}, \mathrm{Et}, \mathrm{Bu}$ ) are highly reactive, and therefore exist only as intermediates. ${ }^{6,}{ }^{24}$ However, the divalent germanium compounds can be stabilized with bulky ligands. Recently, compounds of composition LGeR, where L is a bulky ligand and $\mathrm{R}$ is a small alkyl group, have been investigated. Jutzi and co-workers reported the first examples of such compounds by oxidative addition of MeI, but failed to characterize these compounds by structural analysis. ${ }^{25}$ Therefore it is important to explore the properties of alkylated germanium (II) compounds containing bulky ligands.

\subsection{Divalent Tin (II) Compounds of Type $\operatorname{Sn}(X) R$}

Stable tin(II) compounds of formula $\left(\mathrm{SnR}_{2}\right)_{1 \text { or } 2}$ and $\left(\mathrm{RSn} \mathrm{X}^{1}\right)_{1 \text { or } 2}\left(\mathrm{R}=\right.$ bulky ligand, $\mathrm{X}^{1}=$ halide) are well characterized. ${ }^{1 c, 9 c, 26}$ In contrast, derivatives of $\operatorname{tin}(\mathrm{II})$ of type $\mathrm{Sn}\left(\mathrm{X}^{2}\right) \mathrm{R}$, where $\mathrm{X}^{2}$ is a small ligand other than halide, have received much less attention. To the best of our knowledge, only few of such compounds are known, including $\mathrm{Sn}\left(\mathrm{C}_{7} \mathrm{H}_{7}\right)\left[\mathrm{C}_{6} \mathrm{H}_{3}\right.$ - 2,6$\left.\left(\mathrm{CH}_{2} \mathrm{NMe}_{2}\right)_{2}\right],{ }^{1 \mathrm{~b}}\left[(n \mathrm{Pr})_{2} \mathrm{ATI}\right] \mathrm{SnN}_{3}$ (where $\left[(n \mathrm{Pr})_{2} \mathrm{ATI}\right]^{-}=N$-(npropyl)-2-(npropylamino)- 
troponiminate), $\mathrm{Sn}\left[\mathrm{B}\left(\mathrm{C}_{6} \mathrm{~F}_{5}\right)_{4}\right] \mathrm{Cp},{ }^{27}$ and $\left[\mathrm{Sn}\left(\mathrm{SO}_{3} \mathrm{CF}_{3}\right)\left\{\mathrm{N}\left(\mathrm{SiMe}_{3}\right)_{2}\right\}\right]_{2} \cdot{ }^{28}$ It is of interest to further develop the chemistry of such compounds.

\subsection{Scope and Aim of the Present Work}

Based on the aforementioned acknowledgements, there is clearly a vast potential to use diketiminato ligands to explore the chemistry of divalent germanium and tin.

Hence, the objectives of the present work are:

- To synthesize divalent germanium and tin halides, especially Ge(II) fluorides;

- To synthesize Ge(II) hydrides and investigate their properties;

- To study the synthesis and reactivity of compounds with double bonds between group 14 and 16 elements;

- To develop the chemistry of alkylated Ge(II) compounds containing a bulky ligand;

- To prepare divalent $\mathrm{Sn}(\mathrm{II})$ compounds of type $\mathrm{Sn}(\mathrm{X}) \mathrm{R}$. 


\section{Results and Discussion}

\subsection{Monohalides of Divalent Germanium and Tin}

\subsubsection{Synthesis, Spectroscopic Studies and Structure of Divalent Germanium Chlorides $(3,4)$}

The $\beta$-diketiminato lithium salt $\left[\mathrm{HC}(\mathrm{CMeNAr})_{2}\right] \mathrm{Li}\left(\mathrm{Ar}=2\right.$,6- $\left.i \mathrm{Pr}_{2} \mathrm{C}_{6} \mathrm{H}_{3}\right)$ had been reported previously and used in situ without isolation and characterization. ${ }^{4 a, b}$ Therefore, the crystalline $\left[\mathrm{HC}(\mathrm{CMeNAr})_{2}\right] \operatorname{Li}\left(\mathrm{Et}_{2} \mathrm{O}\right)$ (1) was isolated and characterized spectroscopically. The compound $\left[\mathrm{HC}(\mathrm{CMeNAr})_{2}\right] \mathrm{Li}\left(\mathrm{Et}_{2} \mathrm{O}\right)\left(\mathrm{Ar}=2,6-\mathrm{Me}_{2} \mathrm{C}_{6} \mathrm{H}_{3}\right)(2)$ with a less steric demand than $\mathbf{1}$ has been prepared in a similar way. Reagents $\mathbf{1}$ and $\mathbf{2}$ are soluble in hydrocarbon solvents and are stable under an inert atmosphere without loss of coordinated solvents for a longer period of time.

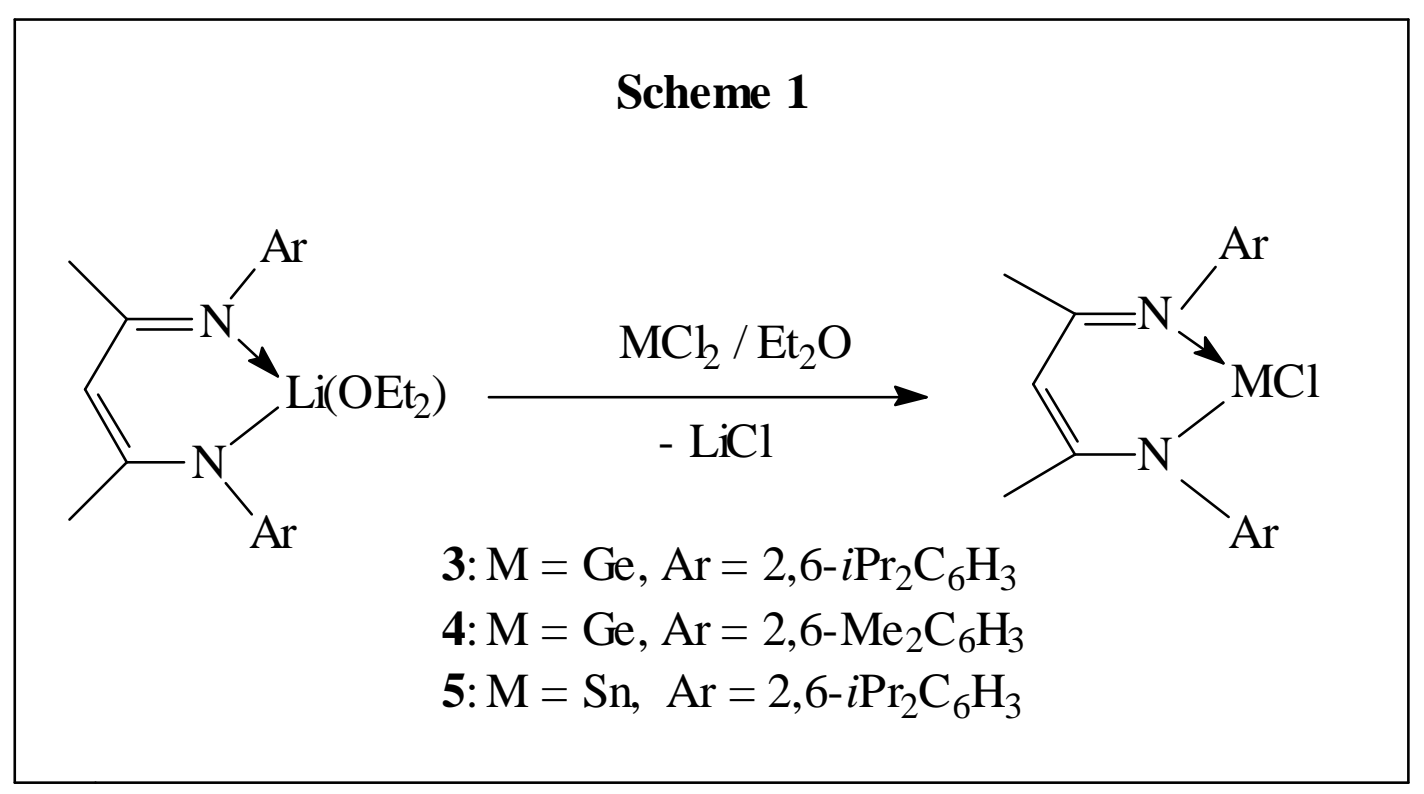

The reaction of $\mathbf{1}$ with one equiv of $\mathrm{GeCl}$.dioxane in diethyl ether at $-78{ }^{\circ} \mathrm{C}$ led to the formation of the $\beta$-diketiminato $\mathrm{Ge}(\mathrm{II})$ chloride $\left[\mathrm{HC}(\mathrm{CMeNAr})_{2}\right] \mathrm{GeCl}\left(\mathrm{Ar}=2,6-i \mathrm{Pr}_{2} \mathrm{C}_{6} \mathrm{H}_{3}\right)$ (3) in high yield (Scheme 1). Colorless crystals of $\mathbf{3}$ can be grown from its $n$ hexane solution in 
a freezer. However, attempts to prepare bis- $\beta$-diketiminato complexes by using 2 equivs of $\mathbf{1}$ were unsuccessful even under more drastic conditions. Compounds $\mathbf{3}$ was fully characterized by elemental analyses, EI-MS, and ${ }^{1} \mathrm{H}$ NMR. In the ${ }^{1} \mathrm{H}$ NMR spectra the resonances of the methyl protons of the aryl substituents, which appear as doublets in the range of $\delta 1.01-1.46$, can be distinguished due to their different environments.

Compound $\left[\left\{\mathrm{HC}(\mathrm{CMeNAr})_{2}\right\} \mathrm{GeCl}\right]\left(\mathrm{Ar}=2,6-\mathrm{Me}_{2} \mathrm{C}_{6} \mathrm{H}_{3}\right)(\mathbf{4})$, the analogue of $\mathbf{3}$, was prepared in a way similar to 3 . With the change of the substituent on the aryl from isopropyl to methyl, compound 4 becomes less soluble than 3 . Both 3 and 4 are soluble in polar solvents (such as $\mathrm{CH}_{2} \mathrm{Cl}_{2}$, and THF); while $\mathbf{3}$ is soluble in hydrocarbons but $\mathbf{4}$ shows only limited solubility. However, compound $\mathbf{4}$ is soluble in hot $\left(70^{\circ} \mathrm{C}\right)$ toluene.

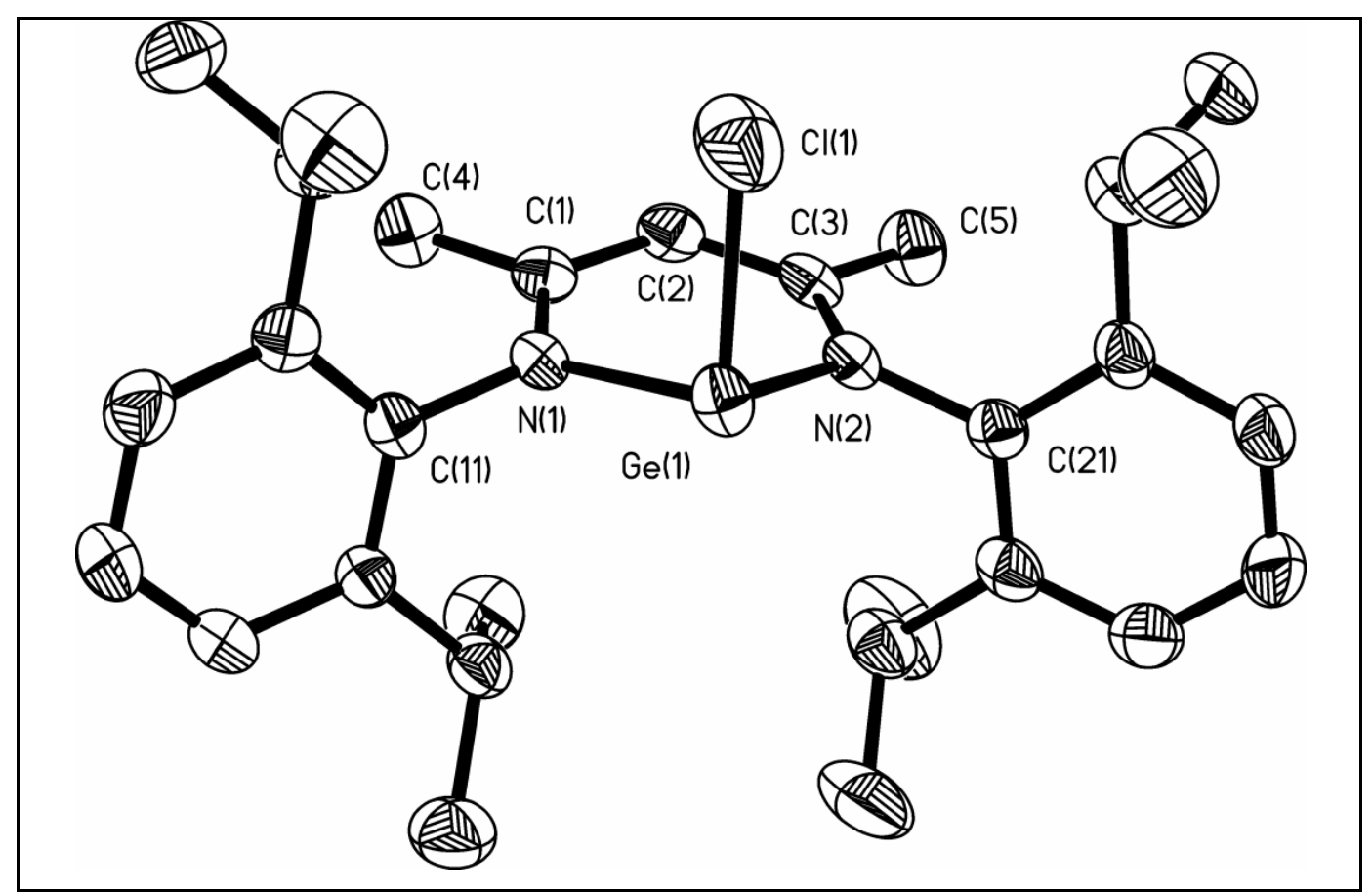

Figure 1. Molecular structure of 3 in the crystal (50\% probability thermal ellipsoids). $\quad H$ atoms are not shown for clarity. Selected bond lengths $(\AA)$ and angles (deg): $\mathrm{Ge}(1)-\mathrm{Cl}(1)$ 2.295(12), $\mathrm{Ge}(1)-\mathrm{N}(1)$ 1.988(2), $\mathrm{Ge}(1)-\mathrm{N}(2)$ 1.997(3), $\mathrm{C}(1)-\mathrm{N}(1)$ 1.339(4), $\mathrm{C}(3)-\mathrm{N}(2)$ 1.333(4); $\mathrm{Cl}(1)-\mathrm{Ge}(1)-\mathrm{N}(1)$ 95.00(8), $\mathrm{Cl}(1)-\mathrm{Ge}(1)$ $-\mathrm{N}(2)$ 95.60(8), N(1)-Ge(1)-N(2) 90.89(10). 
The solid-state structure of compound $\mathbf{3}$ determined by single crystal X-ray diffraction is shown in Figure 1 with selected bond lengths and angles. The X-ray single crystal structure of 3 shows it being monomeric. The ligand chelates the metal which adopts a three fold coordination residing in a distorted tetrahedral environment with one vertex occupied by a lone pair of electrons.

Veith et al. ${ }^{29}$ and Lappert et al. ${ }^{30}$ have reported that the coordinative $\mathrm{N} \rightarrow \mathrm{Ge}$ bonds in the intramolecular $\mathrm{N} \rightarrow$ Ge complexed germylenes are longer $(2.045-2.110 \AA)$ than those of related $\mathrm{Ge}(\mathrm{IV})-\mathrm{N}$ bonds. However, the Ge-N bond lengths observed in 3 (1.988(2), 1.997(3) $\AA$ ) are comparable to Ge(IV)-N $\sigma$ bonds. Similar results were observed in the close analogues in which conjugated ligand backbones are involved. ${ }^{31}$ Previous studies have suggested that conjugated ligand backbones play an important role in improving the stability. ${ }^{32}$ The same applies to compounds $\mathbf{3}$ and affects the $\mathrm{Ge}-\mathrm{N}$ bond lengths. Due to the delocalization of the electrons in the backbone of the ligand, the bond length differences of the C-C bonds $(0.008 \AA)$, the $\mathrm{C}-\mathrm{N}$ bonds $(0.006 \AA)$, and the $\mathrm{Ge}-\mathrm{N}$ bonds $(0.009 \AA)$ are very small. The bond length $\mathrm{Ge}(1)-\mathrm{Cl}(1)(2.295(12) \AA)$ in 3 is $0.092 \AA$ longer than that found in $\mathrm{Ge}(\mathrm{Cl})\left(\mathrm{C}_{6} \mathrm{H}_{3}-2,6\right.$-Trip 2$)(2.203(10) \AA)^{33}$ due to the different coordination number.

\subsubsection{Synthesis, Spectroscopic Studies, and Structure of Divalent Tin Chloride (5)}

Compound $\left[\mathrm{HC}(\mathrm{CMeNAr})_{2}\right] \mathrm{SnCl}\left(\mathrm{Ar}=2,6-i \mathrm{Pr}_{2} \mathrm{C}_{6} \mathrm{H}_{3}(\mathbf{5})\right)$, the tin analogue of $\mathbf{3}$, was readily prepared in a way like that of $\mathbf{3}$ in a $73 \%$ yield (Scheme 1). Storage of its $n$ hexane solution in a $-10{ }^{\circ} \mathrm{C}$ freezer for $2 \mathrm{~d}$ afforded yellow crystals suitable for X-ray diffraction analysis. Compound 5 was fully characterized by elemental analysis, EI-MS, and multinuclear NMR. In the ${ }^{1} \mathrm{H}$ NMR spectra the resonances of the methyl groups of the aryl substituents appeared as doublets and could be distinguished due to their different environments. The ${ }^{119} \mathrm{Sn}$ NMR spectrum of $5(\delta-224 \mathrm{ppm})$ is comparable with that of tin(II) poly(1pyrazolyl)borates in which the metal centers reside in a similar environment. ${ }^{34}$ The EI-MS of 5 exhibits the monomeric molecular ion peak $\mathrm{M}^{+}(572)$ followed by the peak of $[\mathrm{M}-\mathrm{Cl}]^{+}$ (537). 
The solid-state structure of compound $\mathbf{5}$ as determined by single crystal X-ray diffraction is shown in Figure 2 with selected bond lengths and angles. The X-ray single crystal structure of 5 shows it to be monomeric. The ligand chelates to the metal which adopts a three fold coordination and resides in a distorted tetrahedral environment with one vertex occupied by a lone pair of electrons as in the case of $\mathbf{3}$.

The observed $\mathrm{Sn}-\mathrm{N}$ and $\mathrm{Sn}-\mathrm{Cl}$ bond lengths in $\mathbf{5}$ (2.185(2) and 2.180(2) $\AA$ for $\mathrm{Sn}-\mathrm{N}$, 2.473(9) $\AA$ for $\mathrm{Sn}-\mathrm{Cl})$ are comparable to those of the related compounds $(2.162-2.208 \AA$ for $\mathrm{Sn}-\mathrm{N}, 2.468-2.500 \AA$ for $\mathrm{Sn}-\mathrm{Cl}) .^{21,31 \mathrm{a}, 35}$

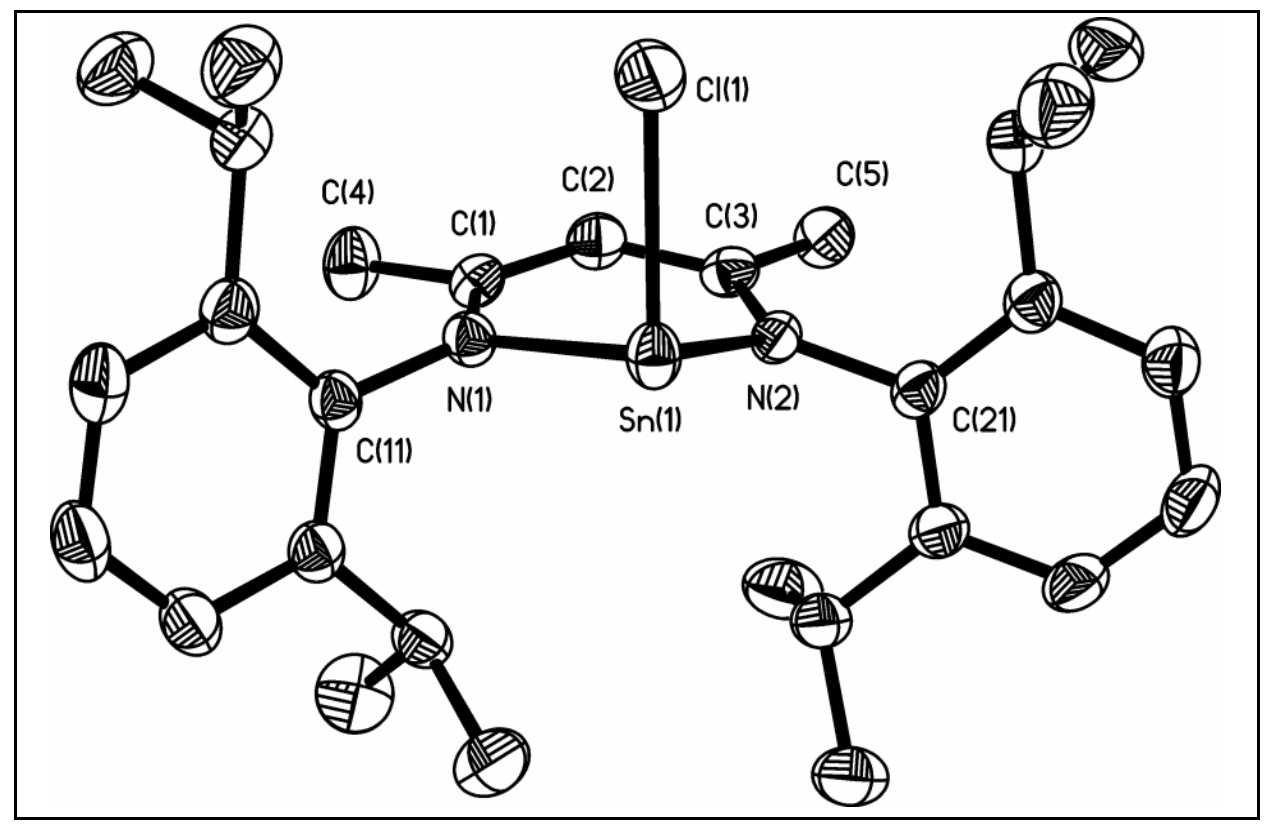

Figure 2. Molecular structure of 5 in the crystal (50\% probability thermal ellipsoids, $H$ atoms are not shown for clarity). Selected bond lengths $(\AA)$ and angles (deg): $\mathrm{Sn}(1)-\mathrm{Cl}(1)$ 2.473(9), $\mathrm{Sn}(1)-\mathrm{N}(1)$ 2.185(2), $\mathrm{Sn}(1)-\mathrm{N}(2) 2.180(2)$, $\mathrm{C}(1)-\mathrm{N}(1)$ 1.329(3), $\mathrm{C}(3)-\mathrm{N}(2)$ 1.343(3); Cl(1)-Sn(1)-N(1) 90.97(6), Cl(1)- Sn(1) $-\mathrm{N}(2)$ 93.47(6), N(1)-Sn(1)-N(2) 85.21(8).

Figures 1 and 2 show compounds $\mathbf{3}$ and $\mathbf{5}$ have similar structural features. But the bond angle $\mathrm{N}(1)-\mathrm{Ge}(1)-\mathrm{N}(2) \quad 90.89(10)^{\circ}$ in $\mathbf{3}$ is larger than the corresponding angle in $\mathbf{5}$ $\left(\mathrm{N}(1)-\mathrm{Sn}(1)-\mathrm{N}(2) 85.21(8)^{\circ}\right)$ and the bond lengths $\mathrm{N}-\mathrm{Ge}(1.998(2)$ and1.997(3) $\AA$ ) in 3 
are slightly shorter than the corresponding N-Sn bond lengths in 5 (2.185(2) and 2.180(2) $\AA$ ), as expected.

The structural features of these divalent compounds $\mathbf{3}$ and $\mathbf{5}$ are different from those of the tetravalent compounds $\mathrm{SnCl}(\mathrm{Me})_{2}\left[\mathrm{CH}\left(\mathrm{CPhNSiMe}_{3}\right)_{2}\right](\mathbf{6})$ and $\mathrm{SnCl}(\mathrm{Me})_{2}\left[\mathrm{CH}(\mathrm{CPhNH})_{2}\right](7)$ in which similar ligands are coordinated to tin. ${ }^{36}$ In compounds $\mathbf{3}$ and $\mathbf{5}$, the backbone of the chelating ligand is essentially planar and the metal atoms lie out of the plane $(0.56 \AA$ in 3 , and $0.66 \AA$ in 5). In compound 6 the central C $(0.086 \AA)$, as well as the Sn atom $(0.76 \AA)$ are out of the $\mathrm{NC}-\mathrm{CN}$ plane. In compound 7, the skeletal atoms including $\mathrm{Sn}$ are almost coplanar. Furthermore, the difference of the two bond lengths of the metal center to the chelating nitrogen atoms in the compounds $\mathbf{3}$ and $\mathbf{5}$ ranges from 0.005 to $0.019 \AA$ A. However, the comparable ones in 6 and in $7(0.201 \AA$ in 6 and $0.109 \AA$ in 7) are significantly longer. Obviously, the larger ionic radius of M(II) (Sn(II) $1.12 \AA$ ) compared to M(IV) ( $\mathrm{Sn}(\mathrm{IV}) 0.71$ $\AA$ ) results in longer $\mathrm{M}(\mathrm{II})-\mathrm{N}$ bond lengths, which are less influenced by the substituents at the metal center.

\subsection{Synthesis, Structure, and Reactivity of Ge (II) Fluorides}

\subsubsection{Synthesis and Spectroscopic Studies of $\left[\mathrm{HC}(\mathrm{CMeNAr})_{2}\right] \mathrm{GeF}(\mathrm{Ar}=2,6$ - $\left.i \mathrm{Pr}_{2} \mathrm{C}_{6} \mathrm{H}_{3}(8), 2,6-\mathrm{Me}_{2} \mathrm{C}_{6} \mathrm{H}_{3}(9)\right)$}

Treatment of $\mathbf{3}$ and $\mathbf{4}$, respectively, with $\mathrm{Me}_{3} \mathrm{SnF}$ in dichloromethane at ambient temperature for $2 \mathrm{~d}$ afforded the corresponding fluorides $\left[\left\{\mathrm{HC}(\mathrm{CMeNAr})_{2}\right\} \mathrm{GeF}\right](\mathrm{Ar}=2,6-$ $i \mathrm{Pr}_{2} \mathrm{C}_{6} \mathrm{H}_{3}$ (8), 2,6- $\mathrm{Me}_{2} \mathrm{C}_{6} \mathrm{H}_{3}(\mathbf{9})$ ) in high yields (88\% and $80 \%$ ) (Scheme 2). Colorless crystals of $\mathbf{8}$ suitable for single crystal X-ray analysis were obtained from a hexane solution at room temperature. Both $\mathbf{8}$ and $\mathbf{9}$ are thermally stable. No decomposition was observed at temperatures below their melting points $\left(182-184^{\circ} \mathrm{C}\right.$ and $186-189^{\circ} \mathrm{C}$, respectively) under an inert atmosphere. EI-MS spectra of $\mathbf{8}$ and $\mathbf{9}$ both show the monomeric molecular ion peaks $\mathrm{M}^{+}$. The ${ }^{19} \mathrm{~F}$ NMR spectra consist of singlet resonances for $\mathrm{Ge}-\mathrm{F}$ ( $\delta 50.58$ and 54.46 ppm, respectively). The IR spectra exhibit the Ge-F stretching frequencies ( $v=543$ and 539 $\mathrm{cm}^{-1}$, respectively) close to those found in $\left[\left(\mathrm{CF}_{3}\right) \mathrm{GeF}_{2}\right]^{-}\left(545 \mathrm{~cm}^{-1}\right)^{10 \mathrm{a}}$ and $\left[\mathrm{GeF}_{6}\right]^{2-}\left(563 \mathrm{~cm}^{-}\right.$ 
$\left.{ }^{1}\right) .{ }^{37}$ The ${ }^{1} \mathrm{H}$ NMR spectra and elemental analyses are also in accordance with $\mathbf{8}$ and $\mathbf{9}$ as formulated.

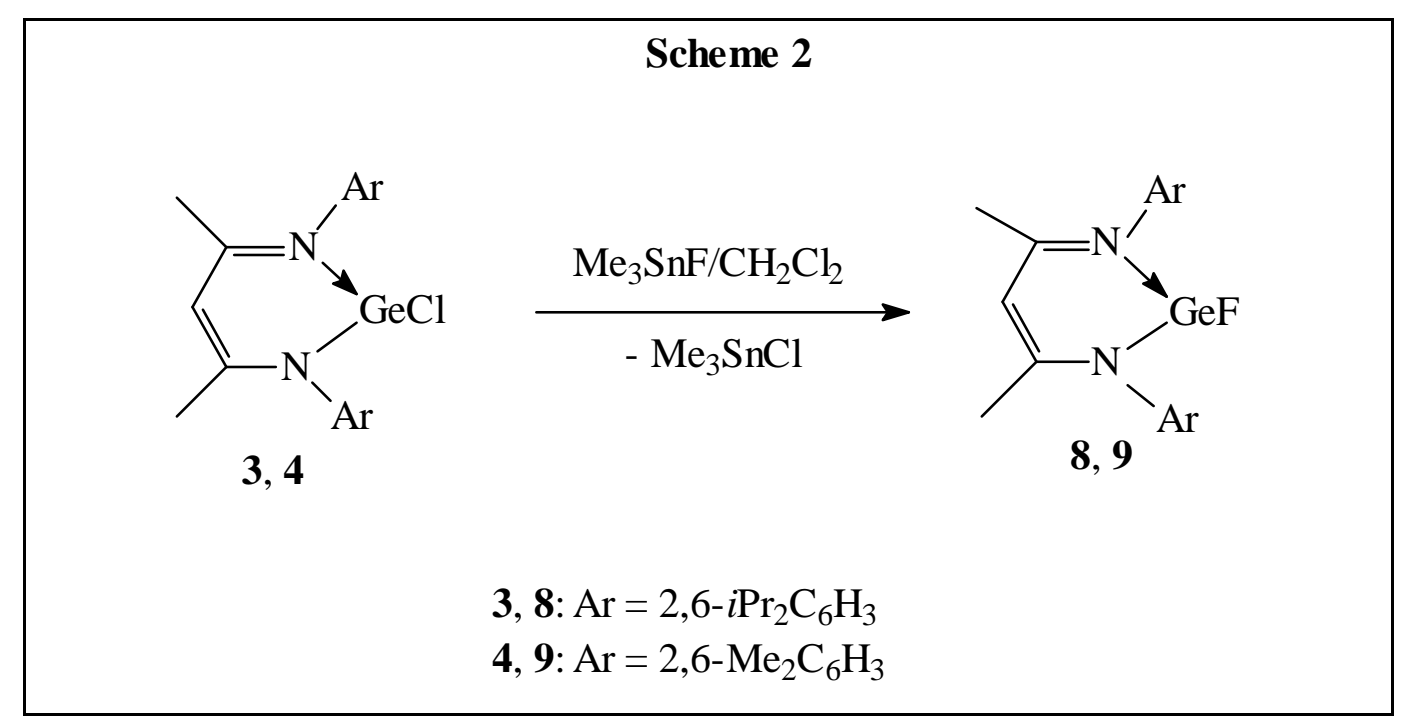

\subsubsection{Single Crystal $X$-ray Structure Investigation of Compound 8}

The solid-state structure of compound $\mathbf{8}$ was determined by single-crystal X-ray diffraction and is shown in Figure 3. Crystallographic data are given in the part of Crystal Data and Refinement Details. Figure 3 shows that compound $\mathbf{8}$ is monomeric. The germanium center is three coordinated. The sum of the angles at the metal center in $\mathbf{8}\left(277.87^{\circ}\right)$ deviates strongly from the $\mathrm{sp}^{3}$ tetrahedral value. Thus, the geometry of $\mathbf{8}$ may be described as pyramidal rather than as distorted tetrahedral. 


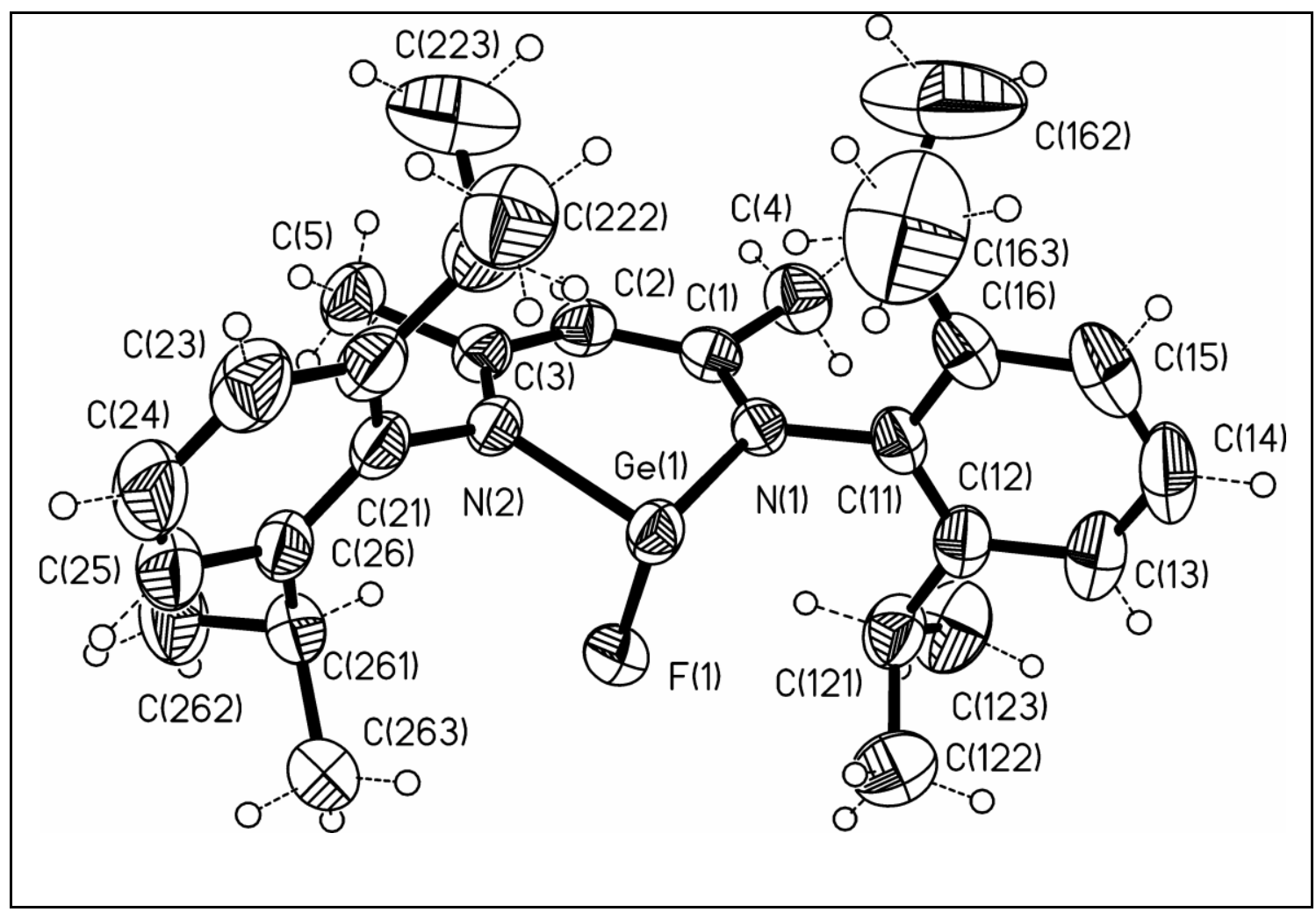

Figure 3. Molecular structure of 8 in the crystal (50\% probability thermal ellipsoids). Selected bond lengths ( $\AA$ ) and angles (deg): $G e(1)-F(1)$ 1.805(17), $\mathrm{Ge}(1)-\mathrm{N}(1)$ 1.977(19), $\mathrm{Ge}(1)-\mathrm{N}(2)$ 1.978(18), C(1)-N(1) 1.333(3), C(3)-N(2) 1.334(4); $F(1)-G e(1)-N(1)$ 93.67(8), $F(1)-G e(1)-N(2)$ 93.16(8), N(1)- Ge(1)$\mathrm{N}(2)$ 91.04(8).

The observed Ge-F bond length $(1.805(17) \AA)$ in $\mathbf{8}$ is in the range $(1.781-1.867 \AA)$ found in Ge(IV) fluorides, ${ }^{10 a, 38}$ no structural data of germanium(II) fluorides are available for comparison with 8. The $\mathrm{N}-\mathrm{Ge}-\mathrm{N}$ angle in $\mathbf{8}\left(91.04(8)^{\circ}\right)$ is larger than that of the starting material $3\left(90.89(10)^{\circ}\right)$, while the Ge-N bonds in $\mathbf{8}(1.977(19)$ and 1.979(18) $\AA$ ) are shorter than those of $\mathbf{3}(1.988(2), 1.997(3) \AA)$. This indicates that the metal center in $\mathbf{8}$ is more closely bound to the ligand. This perhaps results from the weaker electron-withdrawing property of the chlorine atom in $\mathbf{3}$ compared to the fluorine atom in $\mathbf{8}$. 


\subsubsection{Reactivity of 8 and the Formation of $\left[\left\{\mathrm{HC}(\mathrm{CMeNAr})_{2}\right\} \mathrm{Ge}(\mathrm{F}) \mathrm{NSiMe}_{3}\right](\mathrm{Ar}=$ 2,6-i $\left.\operatorname{Pr}_{2} \mathrm{C}_{6} \mathrm{H}_{3}\right)(10)$}

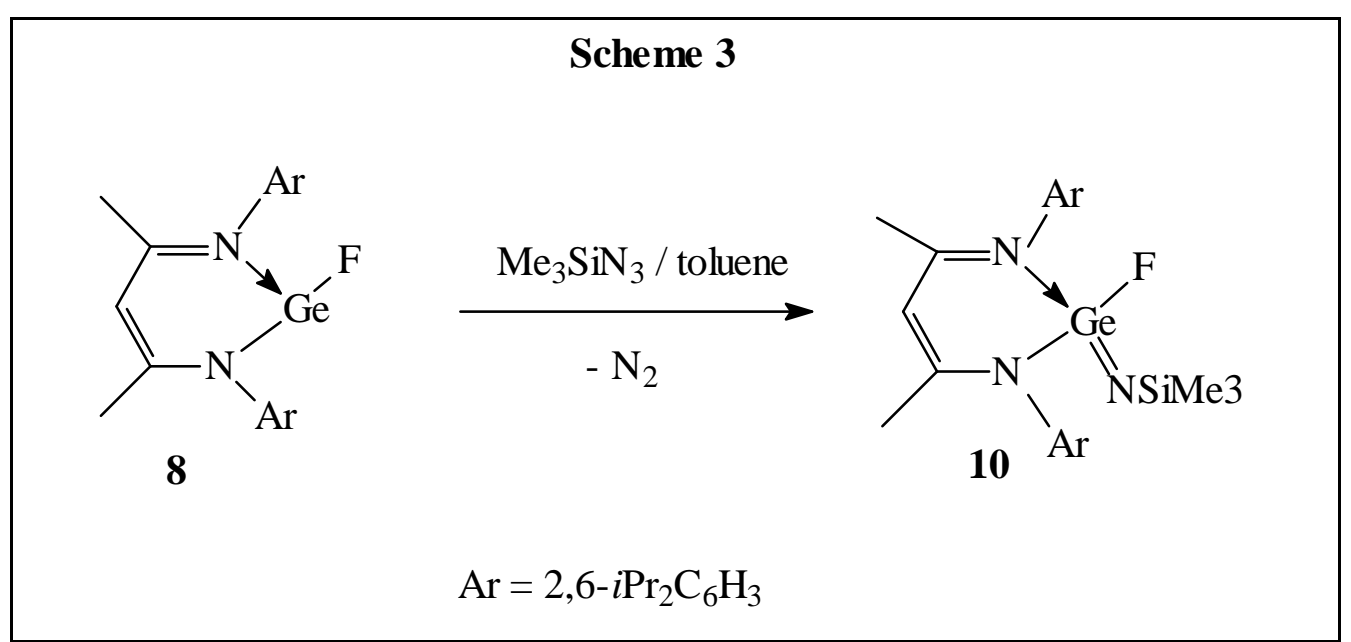

The reactivity of compound $\mathbf{8}$ was examined with trimethylsilyl azide (Scheme 3). Like carbenes, germylenes can react with unsaturated bonds, and the reactions with trimethylsilyl azide have been well studied and established as a route to compounds containing a $\mathrm{Ge}=\mathrm{N}$ double bond. ${ }^{39}$ Refluxing a solution of $\mathbf{8}$ and trimethylsilyl azide in toluene for $3 \mathrm{~h}$ gave the pale yellow compound 10, $\left[\left\{\mathrm{HC}(\mathrm{CMeNAr})_{2}\right\} \mathrm{Ge}(\mathrm{F}) \mathrm{NSiMe}_{3}\right] \quad\left(\mathrm{Ar}=2,6-i \mathrm{Pr}_{2} \mathrm{C}_{6} \mathrm{H}_{3}\right)$, which was characterized by MS, multinuclear NMR $\left({ }^{1} \mathrm{H},{ }^{19} \mathrm{~F}\right.$, and $\left.{ }^{29} \mathrm{Si}\right)$, and elemental analysis. In the mass spectrum the molecular ion $\mathrm{M}^{+}$is observed at $m / z 597(10 \%)$ followed by $[\mathrm{M}-\mathrm{F}]^{+}$ $m / z=578(100 \%)$ with correct isotope patterns. The ${ }^{19} \mathrm{~F}$ NMR chemical shift of $\mathbf{1 0}$ is found at lower field $(\delta 71.04 \mathrm{ppm})$ compared with that of the starting material $\mathbf{8}(\delta 50.58 \mathrm{ppm})$ as expected. The ${ }^{29} \mathrm{Si}$ NMR shows a resonance at $\delta 13.8 \mathrm{ppm}$. The ${ }^{1} \mathrm{H}$ NMR spectrum and elemental analysis are in accordance with the proposed formula of $\mathbf{1 0 .}$ 


\subsection{Synthesis, Structure, and Reactivity of Ge(II) Hydrides}

\subsubsection{Synthesis and Spectroscopic Studies of $\left[\mathrm{HC}(\mathrm{CMeNAr})_{2}\right](\mathrm{GeH}) \mathrm{BH}_{3}(\mathrm{Ar}=\mathbf{2 , 6}$ - $\left.i \operatorname{Pr}_{2} \mathrm{C}_{6} \mathrm{H}_{3}(11), 2,6-\mathrm{Me}_{2} \mathrm{C}_{6} \mathrm{H}_{3}(12)\right)$}

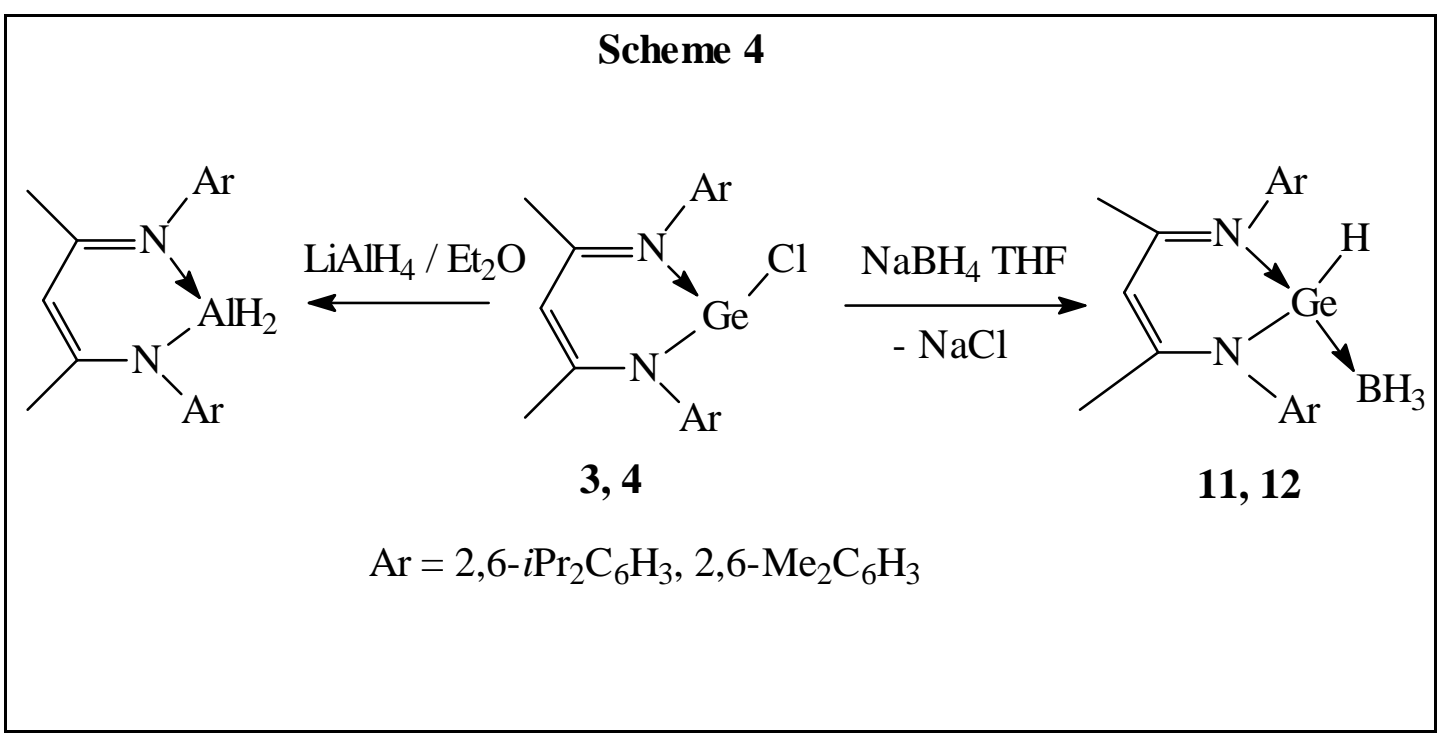

Germanium(IV) and tin(IV) hydrides generally were prepared by the substitution of $\mathrm{X}^{-}$by $\mathrm{H}$

- 40 Treatment of $\mathbf{3}$ with $\mathrm{LiAlH}_{4}$ in diethyl ether at room temperature did not give the expected divalent metal hydrides, instead, the known aluminum hydride $\left[\left\{\mathrm{HC}(\mathrm{CMeNAr})_{2}\right\} \mathrm{AlH}_{2}\right](\mathrm{Ar}=$ 2,6- $\left.i \mathrm{Pr}_{2} \mathrm{C}_{6} \mathrm{H}_{3}\right)^{41}$ was formed by metathesis reaction (Scheme 4). However, refluxing a suspension of $\mathbf{3}$ and $\mathrm{NaBH}_{4}$ in THF for $12 \mathrm{~h}$ enabled us to get the adduct of the germanium hydride with $\mathrm{BH}_{3}$, $\left[\left\{\mathrm{HC}(\mathrm{CMeNAr})_{2}\right\} \mathrm{Ge}(\mathrm{H}) \mathrm{BH}_{3}\right]\left(\mathrm{Ar}=2,6-i \mathrm{Pr}_{2} \mathrm{C}_{6} \mathrm{H}_{3}\right.$ (11)) (Scheme 4). After removal of all the volatiles of the reaction mixture the residue was extracted with diethyl ether. Storage of the slightly green extract at $-32{ }^{\circ} \mathrm{C}$ for $24 \mathrm{~h}$ afforded colorless crystals of $\mathbf{1 1}$ suitable for single crystal X-ray analysis. Compound 12, [\{HC(CMeNAr$\left.\left.)_{2}\right\} \mathrm{Ge}(\mathrm{H}) \mathrm{BH}_{3}\right](\mathrm{Ar}$ $=2,6-\mathrm{Me}_{2} \mathrm{C}_{6} \mathrm{H}_{3}$ ), was prepared in a similar manner.

There is current interest in the behavior of monomeric low coordinated group 14 element compounds as bases towards Lewis acids. Several examples of carbenes, silylenes and 
stannylenes $^{42}$ were reported. Lappert et al. have published the first example of a Lewis acid $\left(\mathrm{BH}_{3}\right)$ adduct of a monomeric intramolecularly base-stabilized germylene $\left[\mathrm{C}_{6} \mathrm{H}_{3}\left(\mathrm{NMe}_{2}\right)_{2}-\right.$ $2,6]_{2} \mathrm{Ge}$

$\mathrm{BH}_{3},{ }^{30}$ and Dias et al. reported on the adduct of a germylene with $\mathrm{BPh}_{3}{ }^{31 \mathrm{~b}}$ Compounds $\mathbf{1 1}$ and 12, the hydride containing germanes feature adduct with $\mathrm{BH}_{3}$.

Both 11 and 12 were characterized by elemental analysis, EI-MS, IR, and ${ }^{1} \mathrm{H}$ and ${ }^{11} \mathrm{~B}$ NMR. In the ${ }^{1} \mathrm{H}$ NMR spectra of $\mathbf{1 1}$ and $\mathbf{1 2}$ the proton signals of the backbone ligand can be clearly distinguished, while the resonance was silent for the proton on the germanium atom even at low temperature (193 K). The ${ }^{1} \mathrm{H}$ NMR spectrum of $\mathbf{1 1}$ exhibits a broad resonance for the $\mathrm{BH}$ protons (toluene- $\mathrm{d}_{8}, 0.8 \mathrm{ppm}$ ) and indicates that there are three hydrogen atoms on the boron atom $(213 \mathrm{~K})$. The ${ }^{11} \mathrm{~B}$ NMR spectra of $\mathbf{1 1}\left(\mathrm{C}_{6} \mathrm{D}_{6}, \delta-41.9 \mathrm{ppm}, \mathrm{q},{ }^{1} J\left({ }^{11} \mathrm{~B}-{ }^{1} \mathrm{H}\right)=\right.$ $95 \mathrm{~Hz})$ and $12\left(\mathrm{C}_{6} \mathrm{D}_{6}, \delta-43.0 \mathrm{ppm}, \mathrm{q},{ }^{1} J\left({ }^{11} \mathrm{~B}-{ }^{1} \mathrm{H}\right)=95 \mathrm{~Hz}\right)$ are similar to that of the complex formula reported by Lappert et al., ${ }^{30}$ confirming that there are three hydrogen atoms on the boron atom. The IR absorptions at $v=1928 \mathrm{~cm}^{-1}$ for $\mathbf{1 1}$ and $1949 \mathrm{~cm}^{-1}$ for $\mathbf{1 2}$, however, are indicative for the existence of a $\mathrm{GeH}$ bond. The reason for the undistinguishable $\mathrm{GeH}$ resonance in the ${ }^{1} \mathrm{H}$ NMR probably is due to the overlap of the resonance with those of the aryl protons. Although the exact mechanism of the formation of $\mathbf{1 1}$ is unclear, $\mathrm{H}$ migration from $\mathrm{BH}_{4}{ }^{-}$to the germanium(II) center may be involved. The formula of $\mathbf{1 1}$ was confirmed by the crystal structure (Figure 4).

\subsubsection{Single Crystal X-ray Structural Investigation of Compound 11}

The solid-state structure of compound $\mathbf{1 1}$ was determined by single-crystal X-ray diffraction and is shown in Figure 4. Crystallographic data are given in the part of Crystal Data and Refinement Details. Figure 4 shows that compound $\mathbf{1 1}$ is monomeric. The germanium center is four coordinated, the sum of the angles, $\mathrm{N}(1)-\mathrm{Ge}(1)-\mathrm{N}(2), \mathrm{N}(1)-\mathrm{Ge}(1)$ $-\mathrm{B}(1)$, and $\mathrm{N}(2)-\mathrm{Ge}(1)-\mathrm{B}(1)$ in $\mathbf{1 1}\left(330.7^{\circ}\right)$ indicates a tetrahedral environment around the metal center. 


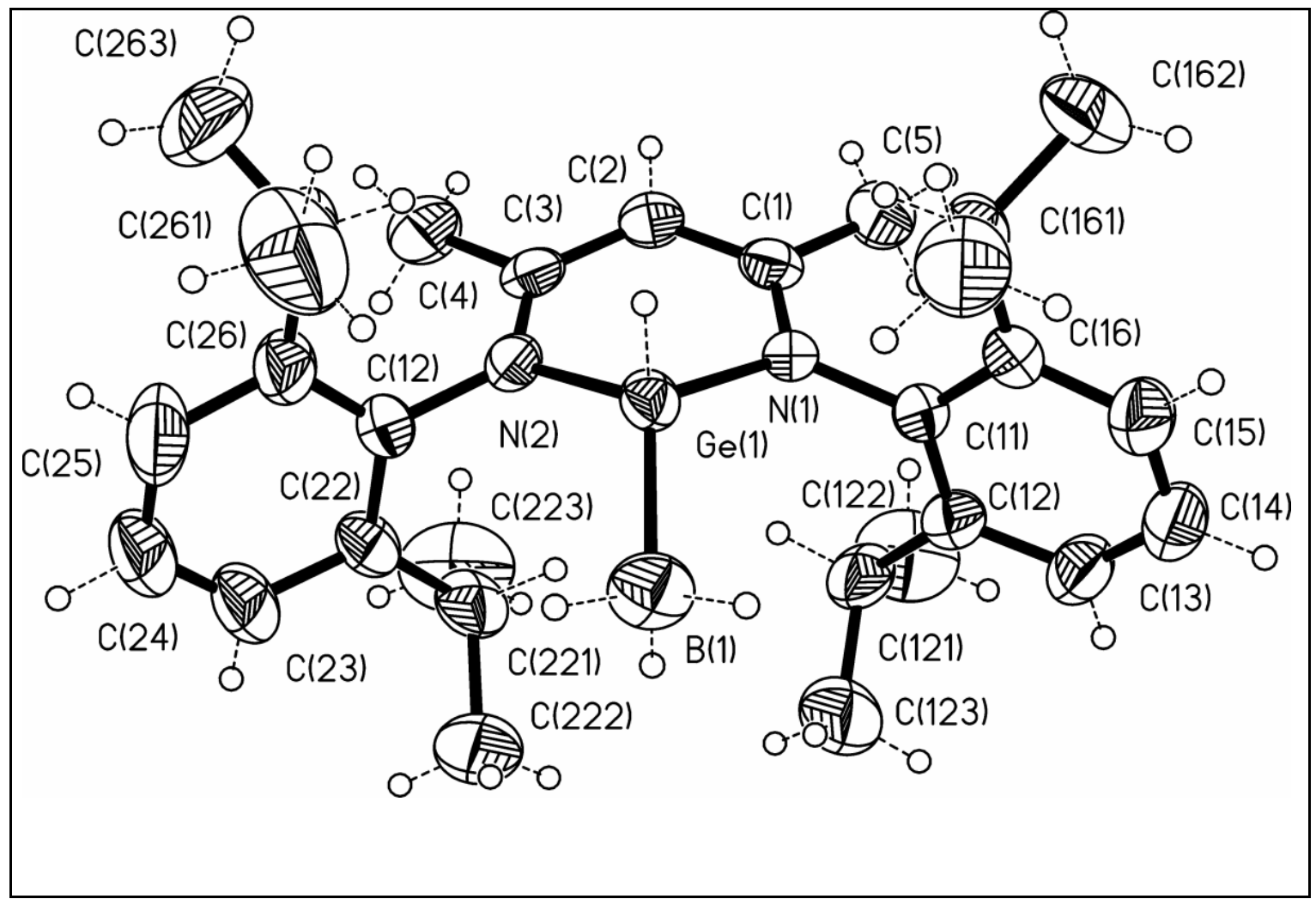

Figure 4. Molecular structure of $\mathbf{1 1}$ in the crystal (50\% probability thermal ellipsoids). Selected bond lengths $(\AA)$ and angles (deg): $G e(1)-B(1) 2.015(7)$, $\mathrm{Ge}(1)-\mathrm{N}(1)$ 1.917(4), $\mathrm{Ge}(1)-\mathrm{N}(2)$ 1.933(4), $\mathrm{C}(1)-\mathrm{N}(1)$ 1.355(7), $\mathrm{C}(3)-\mathrm{N}(2)$ 1.325(7), $C(1)-C(2)$ 1.387(3), C(2)-C(3) 1.393(3), C(1)-C(4) 1.508(3), $C(3)-$ $\mathrm{C}(5) \quad 1.510(3) ; \mathrm{B}(1)-\mathrm{Ge}(1)-\mathrm{N}(1)$ 118.3(3), $\mathrm{B}(1)-\mathrm{Ge}(1)-\mathrm{N}(2)$ 117.9(3), N(1)$\mathrm{Ge}(1)-\mathrm{N}(2) 94.5(2)$.

The Ge-B bond length of $\mathbf{1 1}(2.015(7) \AA)$ is slightly shorter than that of a comparable adduct of another germylene $\mathrm{Ge}\left[\mathrm{C}_{6} \mathrm{H}_{3}\left(\mathrm{NMe}_{2}\right)_{2}-2,6\right]_{2} \mathrm{BH}_{3}(2.041(11) \AA)^{30}$ The order of the corresponding $\mathrm{N}-\mathrm{Ge}-\mathrm{N}$ angles decreases from $11\left(94.5(2)^{\circ}\right)>8\left(91.04(8)^{\circ}\right)>3$ $\left(90.89(10)^{\circ}\right)$, while the Ge-N bond lengths is $\mathbf{1 1}(1.917(4), 1.933(4) \AA)<\mathbf{8}(1.977(19)$, $1.979(18) \AA)<3(1.988(2), 1.997(3) \AA)$. This indicates that the metal center in $\mathbf{1 1}$ is more closely bound to the ligand. This perhaps results from the coordination of the Lewis acid $\left(\mathrm{BH}_{3}\right)$ to the germanium center in $\mathbf{1 1}$ combined with the weak electron-withdrawing property of the chlorine atom in $\mathbf{3}$ compared to the fluorine atom in $\mathbf{8}$. 


\subsubsection{Reactivity of Compound 9 and Its Derivatives 13 and 14}

Although several adducts of monomeric low-valent group 14 element compounds with Lewis acids have been prepared, ${ }^{30,31 b, 42}$ the reactivity of these compounds has not been studied so far. We were thus interested in removing the Lewis acid of such an adducts to obtain the free base. For this purpose $\mathrm{PMe}_{3}$ was used (Scheme 5). Treatment of a solution of 11 in hexane with $\mathrm{Me}_{3} \mathrm{P}$ at room temperature was accompanied by a slight color change from pale yellow to orange. After removal of the solvent the resulting $\mathrm{Me}_{3} \mathrm{PBH}_{3}$ was trapped as a white solid, it was confirmed by ${ }^{1} \mathrm{H},{ }^{11} \mathrm{~B}$, and ${ }^{31} \mathrm{P}$ NMR. Recrystallization of the residue with $n$ hexane afforded orange crystals of $\mathbf{1 3}$. Compound $\mathbf{1 3}$ was characterized by elemental analysis, MS, IR, and multinuclear NMR $\left({ }^{1} \mathrm{H},{ }^{11} \mathrm{~B},{ }^{31} \mathrm{P}\right)$. The ${ }^{11} \mathrm{~B}$ and ${ }^{31} \mathrm{P}$ NMR was silent as expected. Interestingly, the GeH resonance was found ( $\delta 8.04 \mathrm{ppm})$ in the ${ }^{1} \mathrm{H}$ NMR of 13 . The IR absorption at $v=1726 \mathrm{~cm}^{-1}$ was assigned to the $\mathrm{Ge}-\mathrm{H}$ stretching frequency.

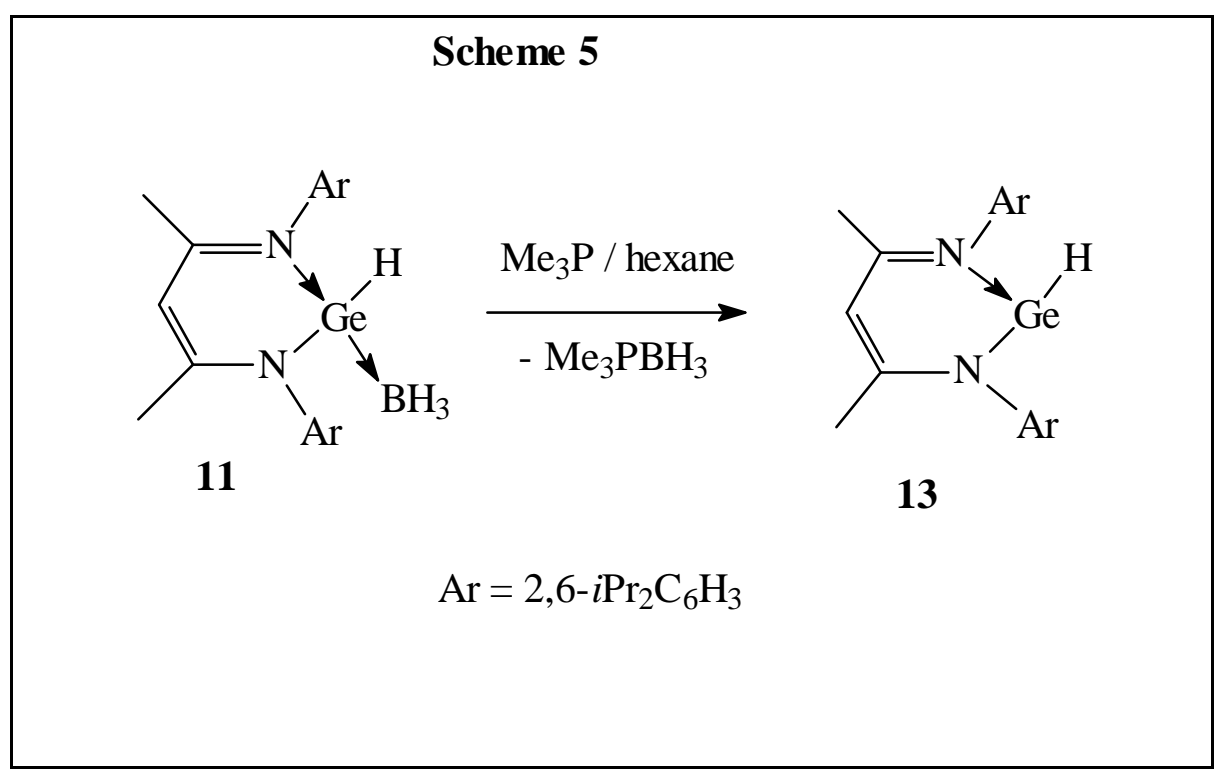

The reactivity of compound $\mathbf{1 1}$ was also preliminarily studied with $t \mathrm{BuLi}$ (Scheme 6). Treatment of a solution of $\mathbf{1 1}$ in diethyl ether with $t \mathrm{BuLi}$ at room temperature led to the formation of $\left[\left\{\mathrm{HC}\left(\mathrm{C}\left(\mathrm{CH}_{2}\right) \mathrm{NAr}\right) \mathrm{CMeNAr}\right\} \mathrm{Ge}(\mathrm{H}) \mathrm{BH}_{3}\right] \cdot \mathrm{Li}\left(\mathrm{Et}_{2} \mathrm{O}\right)_{3}\left(\mathrm{Ar}=2,6-i \mathrm{Pr}_{2} \mathrm{C}_{6} \mathrm{H}_{3}\right)(\mathbf{1 4})$. 
The reaction proceeds with elimination of a hydrogen atom from a methyl group of the ligand backbone and formation of a methylene moiety. This may be due to the relative inertness of the $\mathrm{Ge}-\mathrm{H}$ bond or to the bulky ligand protecting the germanium center. Compound $\mathbf{1 4}$ was characterized by elemental analyses, MS, and multinuclear $\left({ }^{1} \mathrm{H},{ }^{7} \mathrm{Li},{ }^{11} \mathrm{~B}\right) \mathrm{NMR}$. In the ${ }^{1} \mathrm{H}$ NMR spectrum of 14 (toluene- $d_{8}$ ) the resonance clearly show the existence of $\mathrm{GeH}(\delta 6.70$ ppm, br, $1 \mathrm{H}$ ), the $\beta-\mathrm{CH}_{2}$ moiety ( $\delta 3.92 \mathrm{ppm}, \mathrm{s}, 1 \mathrm{H}$ and $\delta 3.20 \mathrm{ppm}, \mathrm{br}, 1 \mathrm{H}$ ), and the $\mathrm{BH}_{3}$ group $(\delta-0.65$ to $-1.15 \mathrm{ppm}$, br, $3 \mathrm{H}$ ), as well as the coordinated diethyl ether molecule $(\delta$ $2.85 \mathrm{ppm}, \mathrm{q}, 12 \mathrm{H}, \mathrm{OCH}_{2} \mathrm{CH}_{3}, J=7.0 \mathrm{~Hz}$ and $\delta 0.79 \mathrm{ppm}, \mathrm{t}, 18 \mathrm{H}, \mathrm{OCH}_{2} \mathrm{CH}_{3}, J=7.0$ Hz). Colorless crystals of $\mathbf{1 4}$ suitable for X-ray diffraction analysis were obtained from a diethyl ether solution at $-32{ }^{\circ} \mathrm{C}$ within $2 \mathrm{~d}$. Although the mechanism for the formation of $\mathbf{1 4}$ is unclear, the most likely one is given in Scheme 6.

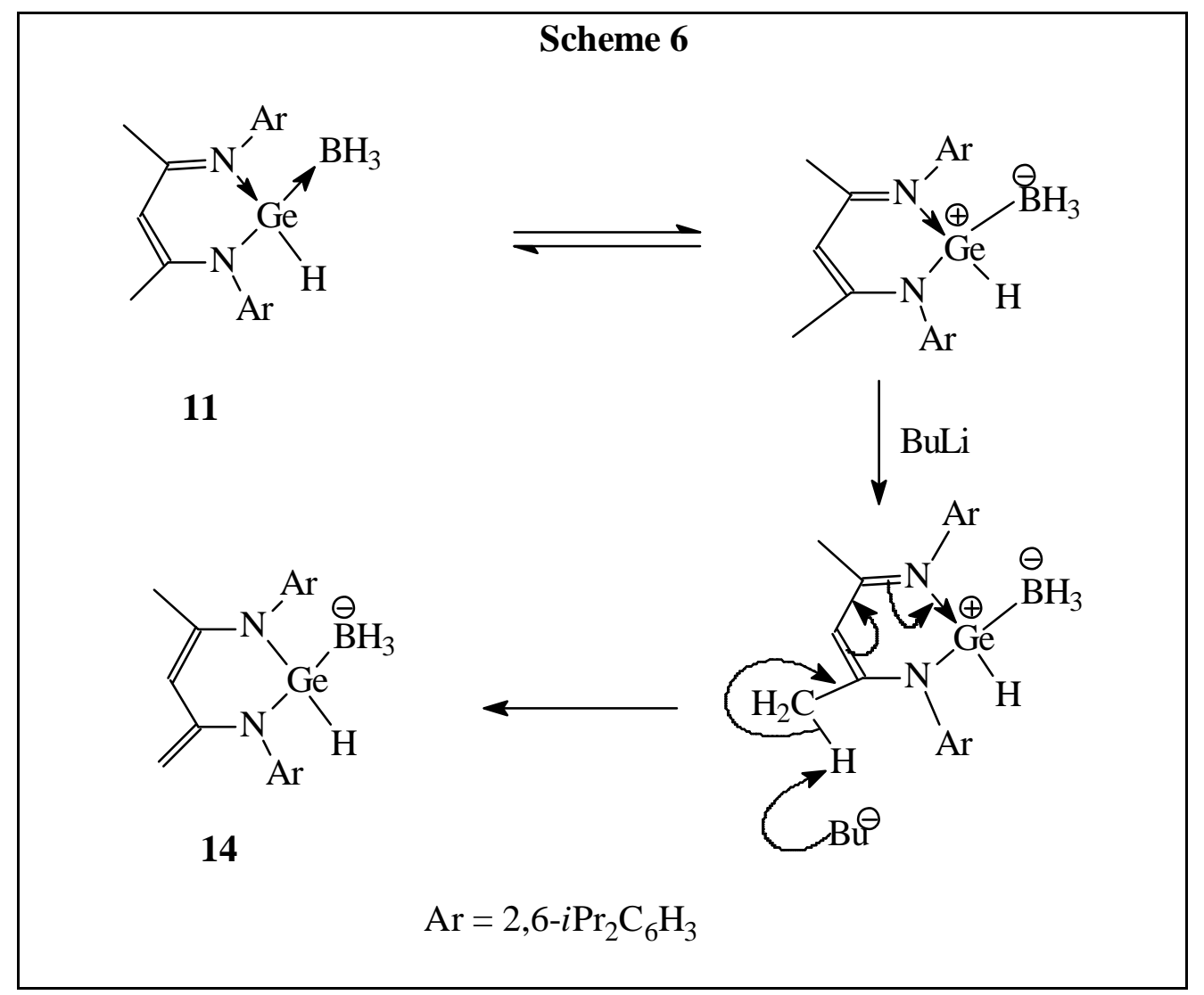

Another important finding for compounds $\mathbf{1 1} \mathbf{- 1 4}$ is their distinct difference in the NMR and IR spectra compared to their Ge(IV) congeners. In the ${ }^{1} \mathrm{H}$ NMR spectra the Ge(IV)H 
resonances are generally observed in the range of $\delta 4-6 \mathrm{ppm},{ }^{15 \mathrm{~b}, \mathrm{c}, 43}$ whereas in $\mathbf{1 3}(\delta 8.04$ ppm, $\left.\mathrm{C}_{6} \mathrm{D}_{6}\right)$ and $\mathbf{1 4}\left(\delta 6.70 \mathrm{ppm}\right.$, toluene- $\left.d_{8}\right)$ they are shifted to lower field.

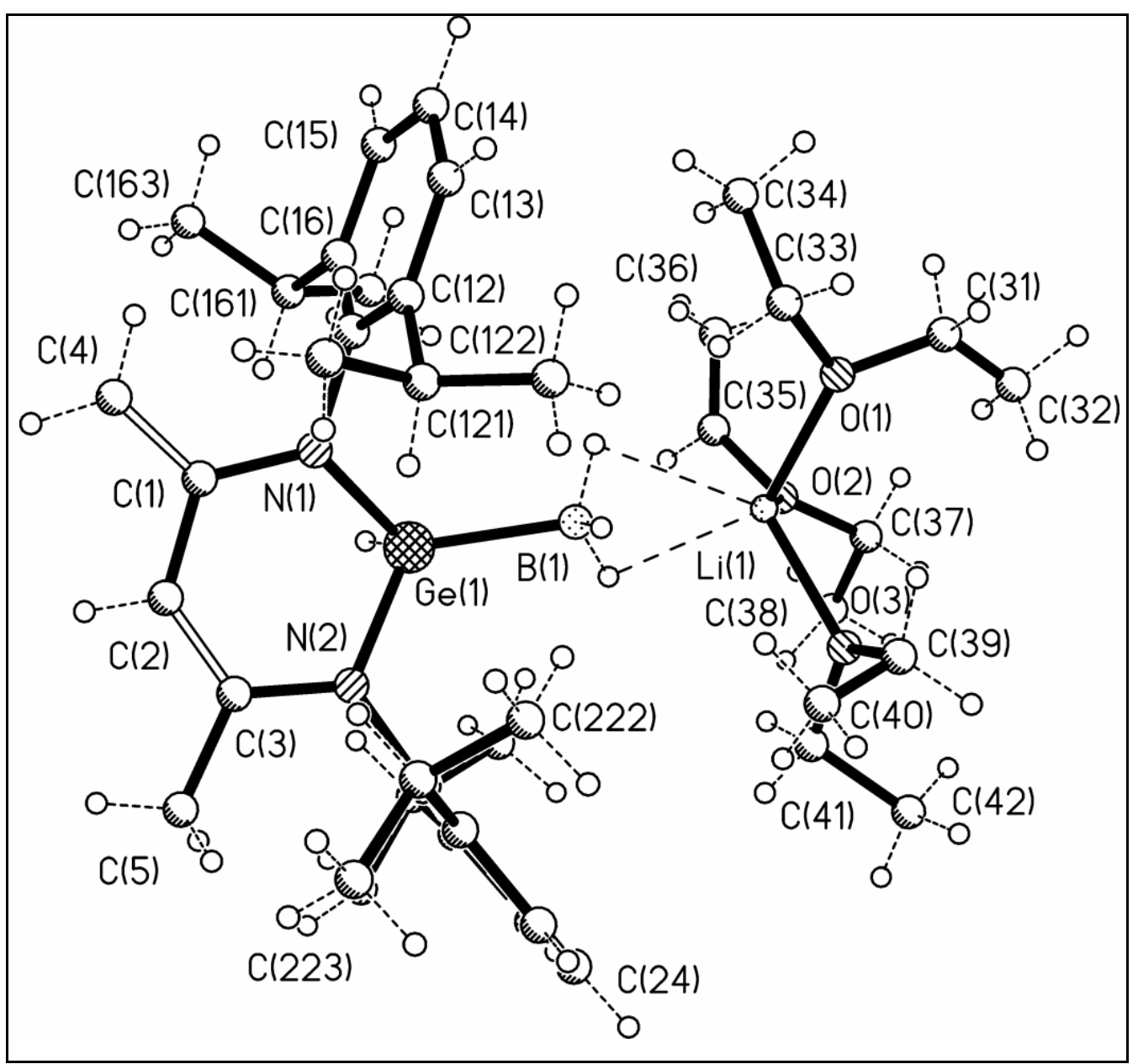

Figure 5. Molecular structure of 14 in the crystal (50\% probability thermal ellipsoids). Selected bond lengths $(\AA \circ)$ and angles (deg): $G e(1)-B(1) 2.016(8)$, $\mathrm{Ge}(1)-\mathrm{N}(1)$ 1.875(4), $\mathrm{Ge}(1)-\mathrm{N}(2)$ 1.879(4), $\mathrm{C}(1)-\mathrm{N}(1)$ 1.377(7), $\mathrm{C}(3)-\mathrm{N}(2)$ 1.380(7), C(1)-C(2) 1.443(8), C(2)-C(3) 1.380(7), C(1)-C(4) 1.384(9), C(3)$\mathrm{C}(5)$ 1.480(8), Li(1)-B(1) 2.382(14); B(1)-Ge(1)-N(1) 115.8(3), B(1)-Ge(1)-N(2) 116.7(3), $\mathrm{Li}(1)-\mathrm{B}(1)-\mathrm{Ge}(1)$ 161.0(6).

The GeH resonances of $\mathbf{1 1}$ and $\mathbf{1 2}$ probably appear in the range of $\delta 6.9-7.2 \mathrm{ppm}$, overlapping with those of the aryl protons. The low field shift of the $\mathrm{GeH}$ resonances in 11 - 
14 compared to those of the Ge(IV) compounds indicates the distinct influence of the free electron pair on the hydrogen atom of the Ge(II) compounds. As a consequence, the $\mathrm{Ge}-\mathrm{H}$ bond in the Ge(II) compounds is more covalent compared to that in the corresponding Ge(IV) species due to the higher electron density around the Ge(II). This is also seen in the IR spectra comparing the $\mathrm{Ge}-\mathrm{H}$ stretching frequencies. In the compound $\mathrm{Mes}_{2} \mathrm{HGe}(\mathrm{Li} \cdot$ crown$4),{ }^{43}$ the electron density is increased compared to neutral Ge(IV)H compounds exhibiting a low Ge-H absorption at $v=1980 \mathrm{~cm}^{-1}$. The germanium(II) hydrides, $11-\mathbf{1 3}$ show absorptions even at lower wave numbers $\left(v=1927,1949\right.$ and $1726 \mathrm{~cm}^{-1}$, respectively). This applies especially for compound $\mathbf{1 3}$ without coordinating $\mathrm{BH}_{3}$.

The solid-state structure of compound $\mathbf{1 4}$ was determined by single-crystal X-ray diffraction and is shown in Figure 5. Crystallographic data are given in the part of Crystal Data and Refinement Details. Figure 5 shows that compound 14 is monomeric. The germanium atom is four coordinated, the sum of the angles, $\mathrm{N}(1)-\mathrm{Ge}(1)-\mathrm{N}(2), \mathrm{N}(1)-\mathrm{Ge}(1)-$ $\mathrm{B}(1)$, and $\mathrm{N}(2)-\mathrm{Ge}(1)-\mathrm{B}(1)$ around the metal center in $\mathbf{1 4}\left(328^{\circ}\right)$ is tetrahedral.

The Ge-B bond length in $14(2.016(8) \AA)$ is slightly shorter $(0.001 \AA)$ than that of the starting material $11(2.015(7) \AA)$ due to the influence of the lithium atom. The B-Li distance in 14 (2.382(14) $\AA$ ) is longer than the sum of covalent radii (2.03 $\AA$ ). The large bond angle $\left(161.0(6)^{\circ}\right)$ of $\mathrm{Li}(1)-\mathrm{B}(1)-\mathrm{Ge}(1)$ indicates that the lithium atom is far away from the germanium atom. The $\mathrm{C}(1)-\mathrm{C}(4)(1.384(9) \AA)$ bond length is much shorter than $\mathrm{C}(3)-\mathrm{C}(5)$ $(1.480(8) \AA)$ in 14 and in $11(1.499(9), 1.513(8) \AA)$ indicating that the $\mathrm{C}(1)-\mathrm{C}(4)$ and $\mathrm{C}(2)-\mathrm{C}(3)$ bonds in $\mathbf{1 4}$ have double-bond character. 
2.4. Synthesis, Structure, and Reactivity of Compounds Involving Multiple Bonded Heavier Main Group Elements Bearing a Halide: Derivatives from the Divalent Halides

\subsubsection{Synthesis and Structures of $\left[\left\{\mathrm{HC}(\mathrm{CMeNAr})_{2}\right\} \mathrm{Ge}(\mathrm{S}) \mathrm{X}\right]\left(\mathrm{Ar}=2,6-i \mathrm{Pr}_{2} \mathrm{C}_{6} \mathrm{H}_{3}, \mathrm{X}=\right.$ Cl 15, F 16, Me 17)}

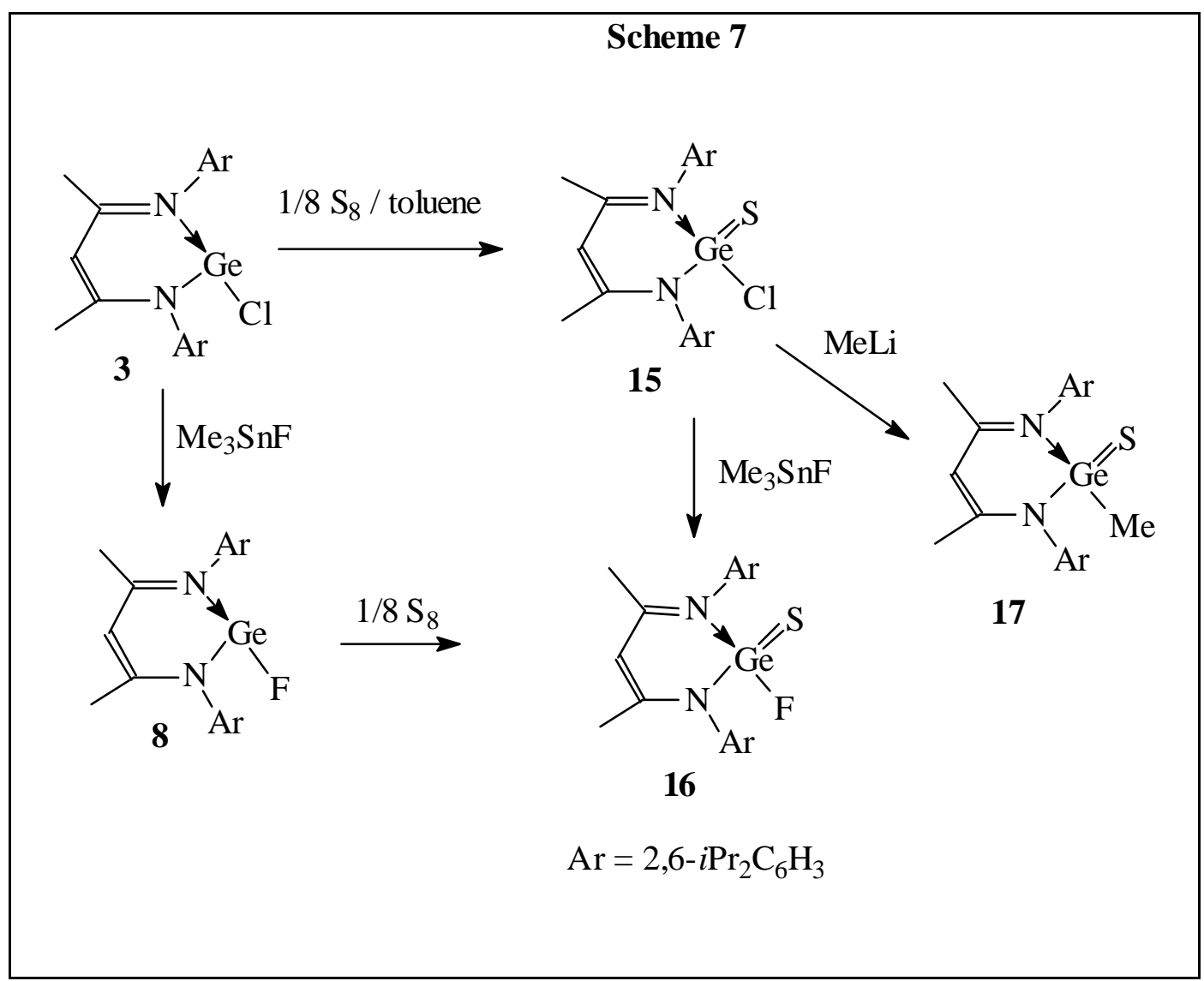

Treatment of $\mathbf{3}$ with elemental sulfur in toluene at ambient temperature for $2 \mathrm{~d}$ afforded $\left[\left\{\mathrm{HC}(\mathrm{CMeNAr})_{2}\right\} \mathrm{Ge}(\mathrm{S}) \mathrm{Cl}\right]\left(\mathrm{Ar}=2,6-i \mathrm{Pr}_{2} \mathrm{C}_{6} \mathrm{H}_{3}(\mathbf{1 5})\right)$ in an excellent yield $(88 \%)$ (Scheme 7). Pale yellow crystals of $\mathbf{1 5}$ were obtained from a toluene solution at $-32{ }^{\circ} \mathrm{C}$. The fluoro analogue $\left[\left\{\mathrm{HC}(\mathrm{CMeNAr})_{2}\right\} \mathrm{Ge}(\mathrm{S}) \mathrm{F}\right](\mathbf{1 6})$, which is expected to have a different reactivity due to the strong electron withdrawing property compared to the other halides, can be generated by two routes: from 15 by the fluorination with $\mathrm{Me}_{3} \mathrm{SnF}$ or from 8 by oxidative addition with elemental sulfur (Scheme 7). Both methods yield colorless crystals from toluene solutions. The reactivity of $\mathbf{1 5}$ was preliminarily examined using the smallest alkylating reagent MeLi 
(Scheme 7). Treatment of $\mathbf{1 5}$ with MeLi led to the formation of [ $\left.\left\{\mathrm{HC}(\mathrm{CMeNAr})_{2}\right\} \mathrm{Ge}(\mathrm{S}) \mathrm{Me}\right]$ (17). The so far known structurally characterized doubly bonded heavier group 14 elements are bound to bulky ligands. With this reaction a small alkyl group was introduced into such a system for the first time.

Compounds $\mathbf{1 5}$ - 17 were characterized by elemental analysis, EI-MS, ${ }^{1} \mathrm{H}$ and ${ }^{19} \mathrm{~F}$ NMR. All results are in accordance with the corresponding formulae.

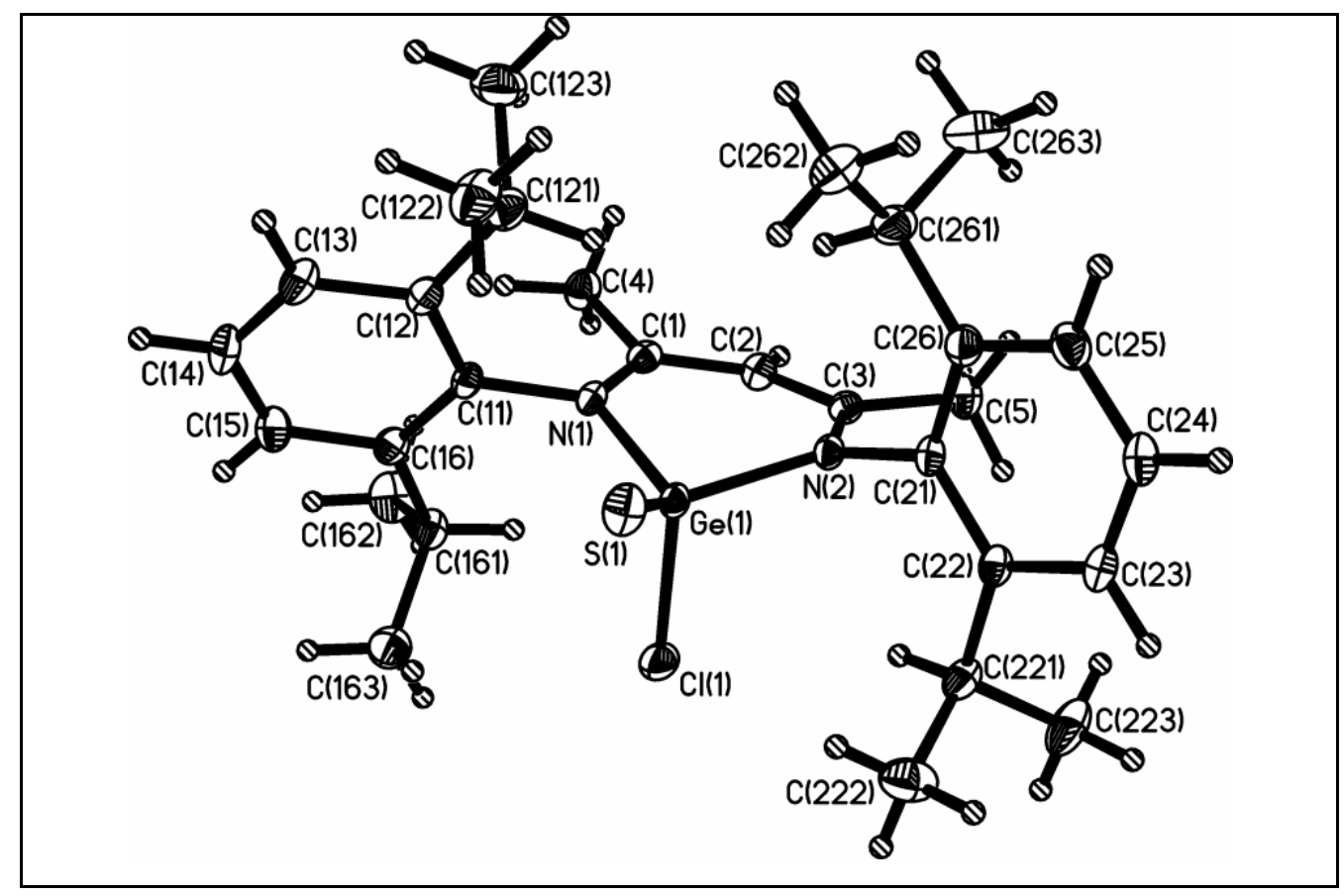

Figure 6. Molecular structure of $\mathbf{1 5}$ in the crystal (50\% probability thermal ellipsoids). Selected bond lengths (Å) and angles (deg): $\mathrm{Ge}(1)-\mathrm{Cl}(1) 2.195(7)$, $\mathrm{Ge}(1)-\mathrm{S}(1)$ 2.053(6), $\mathrm{Ge}(1)-\mathrm{N}(1)$ 1.881(1), Ge(1)-N(2) 1.910(1); S(1)-Ge(1)$\mathrm{N}(1)$ 118.87(4), S(1)- Ge(1)-N(2) 118.33(4), S(1)- Ge(1)-Cl(1) 116.82(2), N(1)$\mathrm{Ge}(1)-\mathrm{N}(2)$ 98.18(6), Cl(1)-Ge(1)-N(1) 99.51(4), Cl(1)-Ge(1)-N(2) 101.54(5).

The solid state structures of $\mathbf{1 5} \mathbf{- 1 7}$ were determined by single crystal X-ray diffraction. Compound 15 crystallizes in the space group $P 2_{1} / c, 16$ and 17 in the space group $P 2_{1} / n$. The structures of the monomeric compounds $\mathbf{1 5 - 1 7}$ are shown in Figures 6-8. Selected bond lengths and bond angles are given in the legends. The germanium centers adopt four- 
coordinated geometries and reside in distorted tetrahedral environments. The geometries are similar to other compounds containing terminal chalcogenido germanium units. ${ }^{21 \mathrm{~d}}$

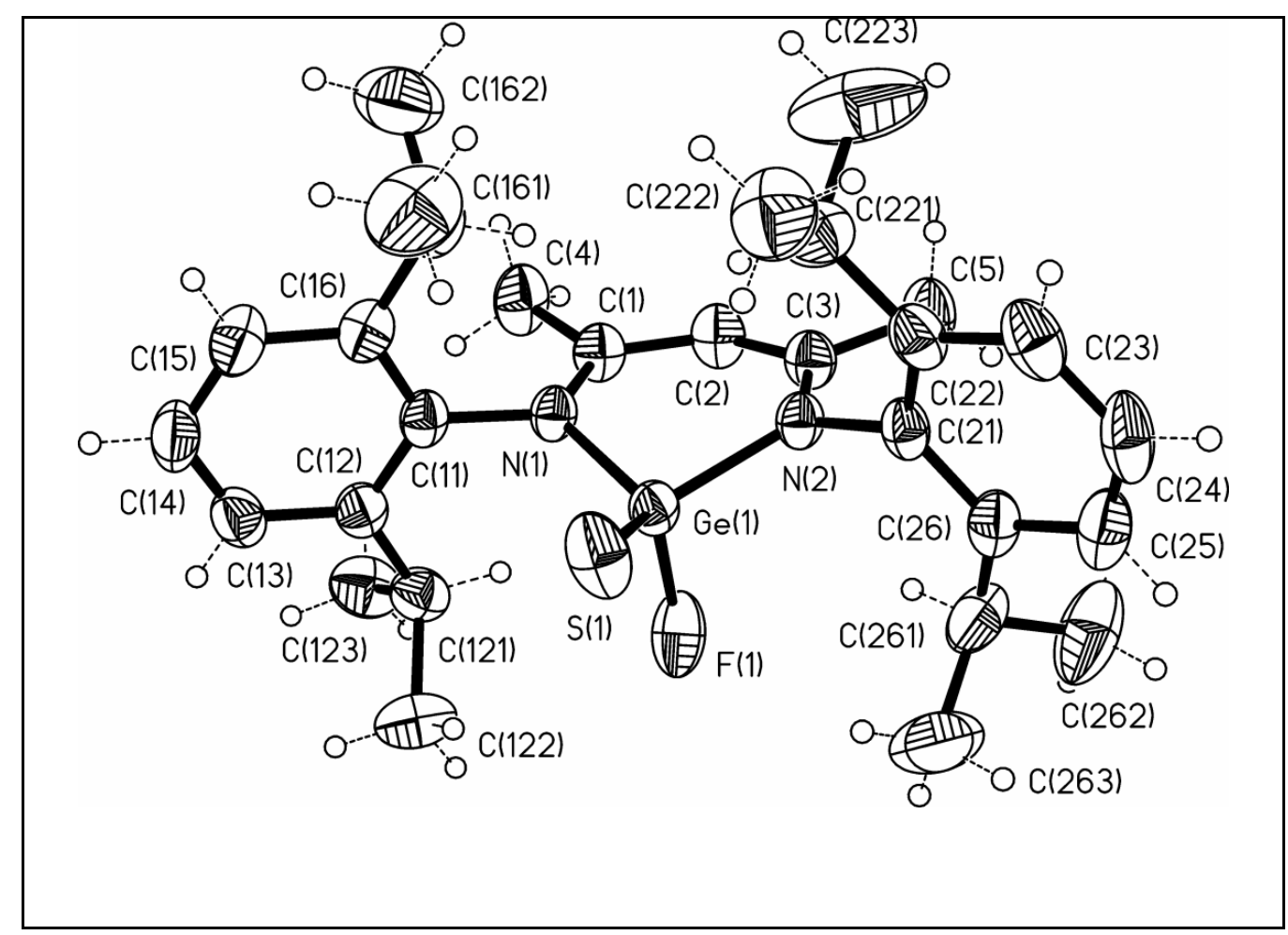

Figure 7. Molecular structure of $\mathbf{1 6}$ in the crystal (50\% probability thermal ellipsoids). Selected bond lengths $(\AA)$ and angles (deg): $G e(1)-F(1)$ 1.848(2), $\mathrm{Ge}(1)-\mathrm{S}(1)$ 2.050(9), $\mathrm{Ge}(1)-\mathrm{N}(1)$ 1.892(2), Ge(1)-N(2) 1.884(2); S(1)-Ge(1)$\mathrm{N}(1)$ 120.14(7), S(1)-Ge(1)-N(2) 119.58(7), S(1)-Ge(1)-F(1) 116.57(8), N(1)$\mathrm{Ge}(1)-\mathrm{N}(2)$ 97.69(10), F(1)-Ge(1)-N(1) 99.07(9), F(1)-Ge(1)-N(2), 99.61(9).

The Ge-S bond lengths (2.053(6) $\AA$ in 15, 2.050(9) $\AA$ in 16, and 2.104(7) $\AA$ in 17), are shorter than the Ge-S single bond length (2.239(1) A) reported, ${ }^{21 e}$ in agreement with those $\left(2.063(3) \AA^{29 a}\right.$ and 2.045(3) $\left.\AA^{21 f}\right)$ reported for other $\mathrm{Ge}=\mathrm{S}$ compounds. The $\mathrm{Ge}=\mathrm{S}$ bond length in $15(2.053(6) \AA)$ is comparable to that in 16 (2.050(9) $\AA$ ) but distinctly shorter $(0.051 \AA)$ than that of $\mathbf{1 7}$ due to the difference of the electron withdrawing abilities of $\mathrm{F}, \mathrm{Cl}$. This property also influences the average Ge-N bond lengths $(16(1.888 \AA)<\mathbf{1 5}(1.895 \AA)$ $<\mathbf{1 7}(1.941 \AA))$. The Ge-Cl bond length in $\mathbf{1 5}(2.195(7) \AA)$ is $0.10 \AA$ shorter than that in the 
starting material 3 (2.295(1) $\AA$ ) as expected from the higher oxidation state of the product. The Ge-F bond length in $\mathbf{1 6}(1.848(2) \AA)$ is in the expected range $\left(1.781(10)^{10 \mathrm{~b}}\right.$ to $\left.1.867(14) \AA^{38}\right)$.

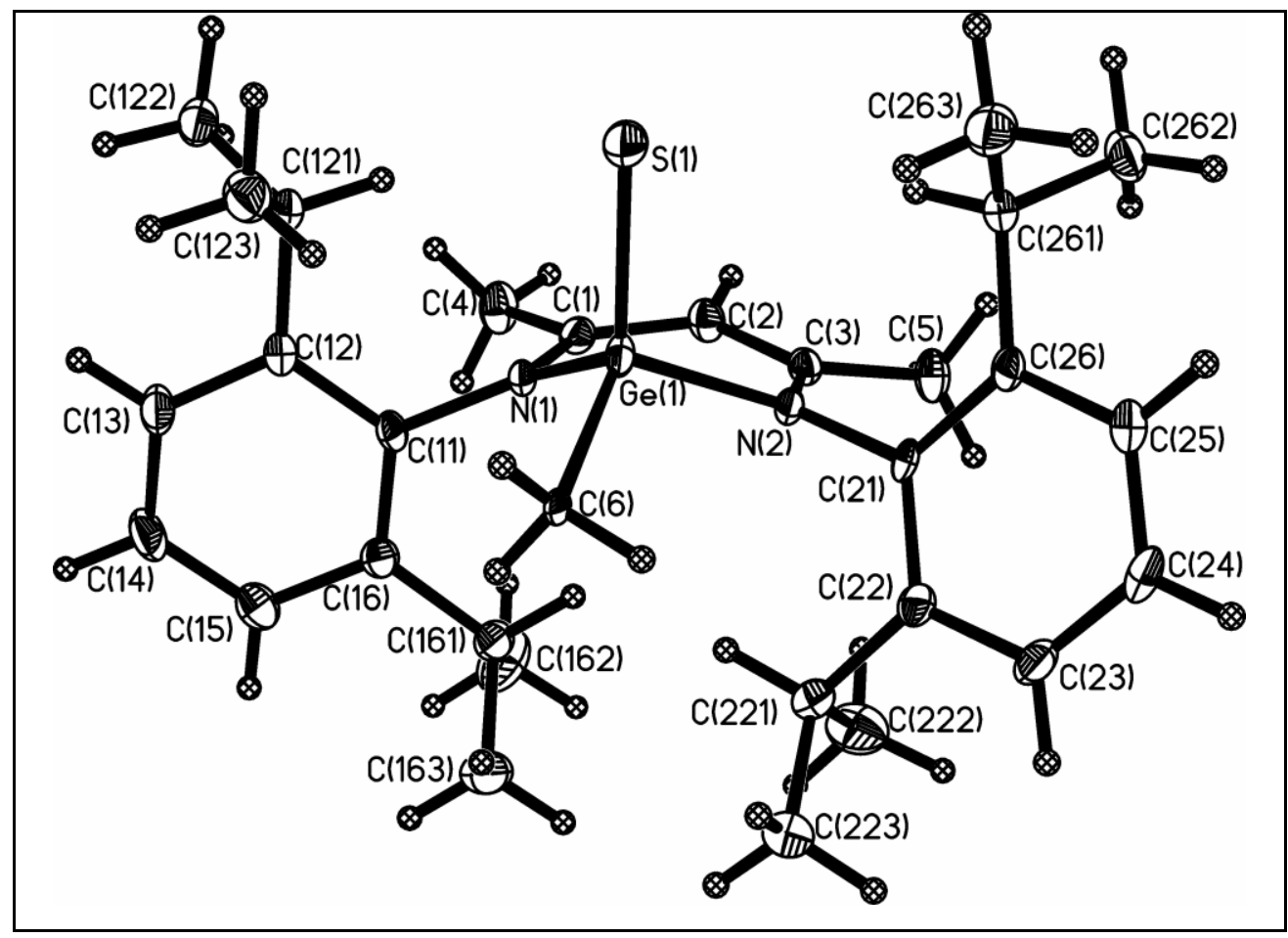

Figure 8. Molecular structure of $\mathbf{1 7}$ in the crystal (50\% probability thermal ellipsoids). Selected bond lengths (Å) and angles (deg): $G e(1)-C(6) 2.009(2)$, $\mathrm{Ge}(1)-\mathrm{S}(1)$ 2.104(7), $\mathrm{Ge}(1)-\mathrm{N}(1)$ 1.930(2), Ge(1)-N(2) 1.952(2); S(1)-Ge(1)$\mathrm{N}(1)$ 111.54(5), S(1)-Ge(1)-N(2) 110.41(5), S(1)-Ge(1)-C(6) 120.25(6), N(1)$\mathrm{Ge}(1)-N(2)$ 94.15(10), C(6)-Ge(1)-N(1) 107.69(8), C(6)-Ge(1)-N(2) 109.66(8).

In summary, we have prepared and fully characterized the heterocycles $\left[\left\{\mathrm{HC}(\mathrm{CMeNAr})_{2}\right\} \mathrm{Ge}(\mathrm{S}) \mathrm{X}\right]\left(\mathrm{Ar}=2,6-i \mathrm{Pr}_{2} \mathrm{C}_{6} \mathrm{H}_{3}, \mathrm{X}=\mathrm{F}, \mathrm{Cl}, \mathrm{Me}\right)$. The first two complexes are the first structurally characterized examples of multiply bonded heavier organometallic group 14 compounds bearing a halide and are potentially important precursors for further reactions. 


\subsubsection{Synthesis and Structures of $\left[\left\{\mathrm{HC}(\mathrm{CMeNAr})_{2}\right\} \mathrm{Ge}(\mathrm{Se}) \mathrm{X}\right]\left(\mathrm{Ar}=2,6-i \mathrm{Pr}_{2} \mathrm{C}_{6} \mathrm{H}_{3}, \mathrm{X}\right.$ = Cl (18), F (19), $n \mathrm{Bu}(20))$}

The selenium analogues of compounds $\mathbf{1 5}$ - $\mathbf{1 7}$ have also been prepared (Scheme 8).

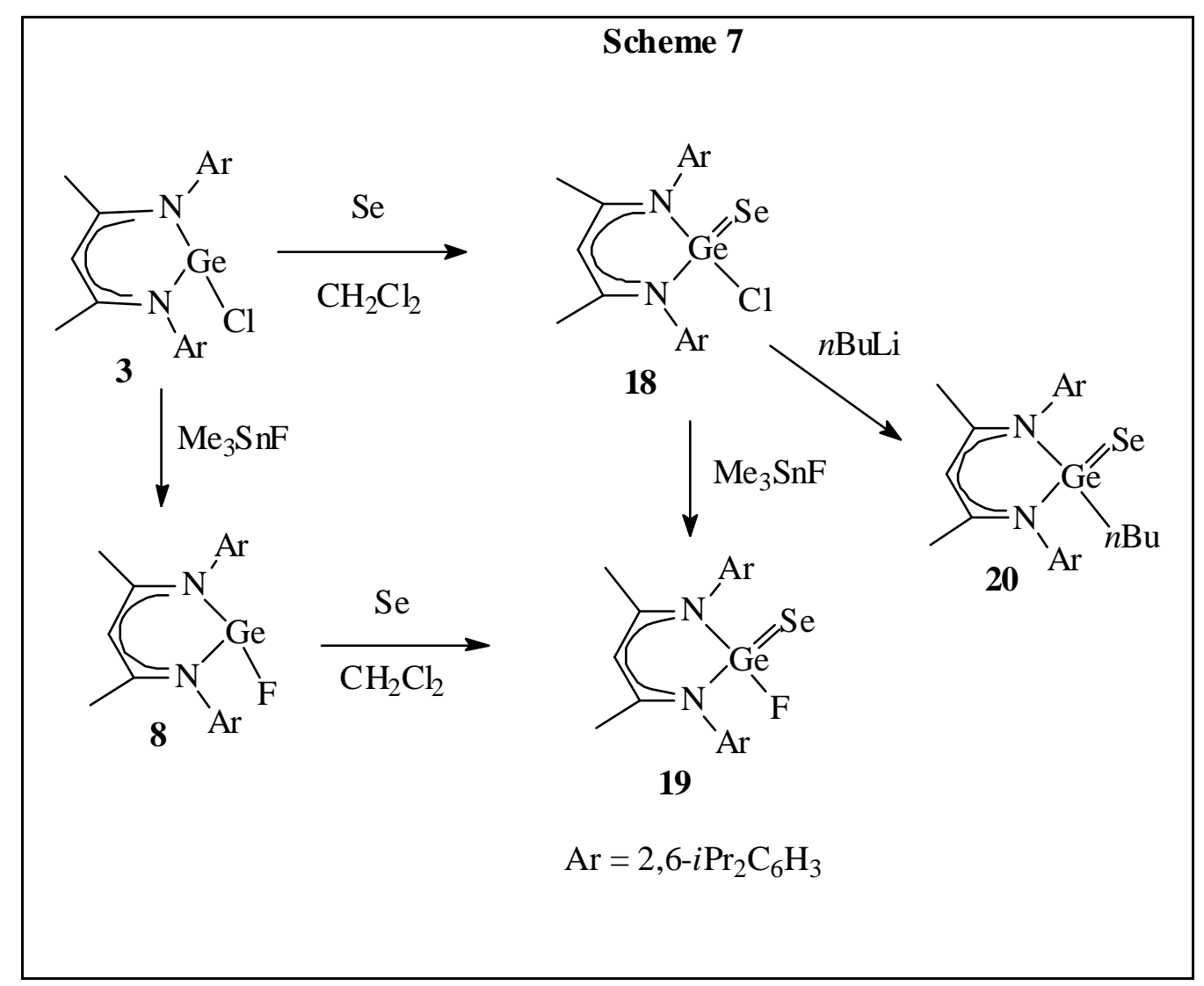

Treatment of $\mathbf{3}$ with elemental selenium in dichloromethane at ambient temperature for $24 \mathrm{~h}$ afforded $\left[\left\{\mathrm{HC}(\mathrm{CMeNAr})_{2}\right\} \mathrm{Ge}(\mathrm{Se}) \mathrm{Cl}\right]\left(\mathrm{Ar}=2,6-i \mathrm{Pr}_{2} \mathrm{C}_{6} \mathrm{H}_{3}(\mathbf{1 8})\right)$. Pale yellow crystals of $\mathbf{1 8}$ can be obtained from the dichloromethane solution at $-32{ }^{\circ} \mathrm{C}$ in a $87 \%$ yield. The fluoro analogue $\left[\left\{\mathrm{HC}(\mathrm{CMeNAr})_{2}\right\} \mathrm{Ge}(\mathrm{Se}) \mathrm{F}\right](\mathbf{1 9})$ also can be generated by two routes: from 18 by the fluorination with $\mathrm{Me}_{3} \mathrm{SnF}$ or from 8 by oxidative addition of elemental selenium (Scheme 8) yielding colorless crystals from toluene solutions. 


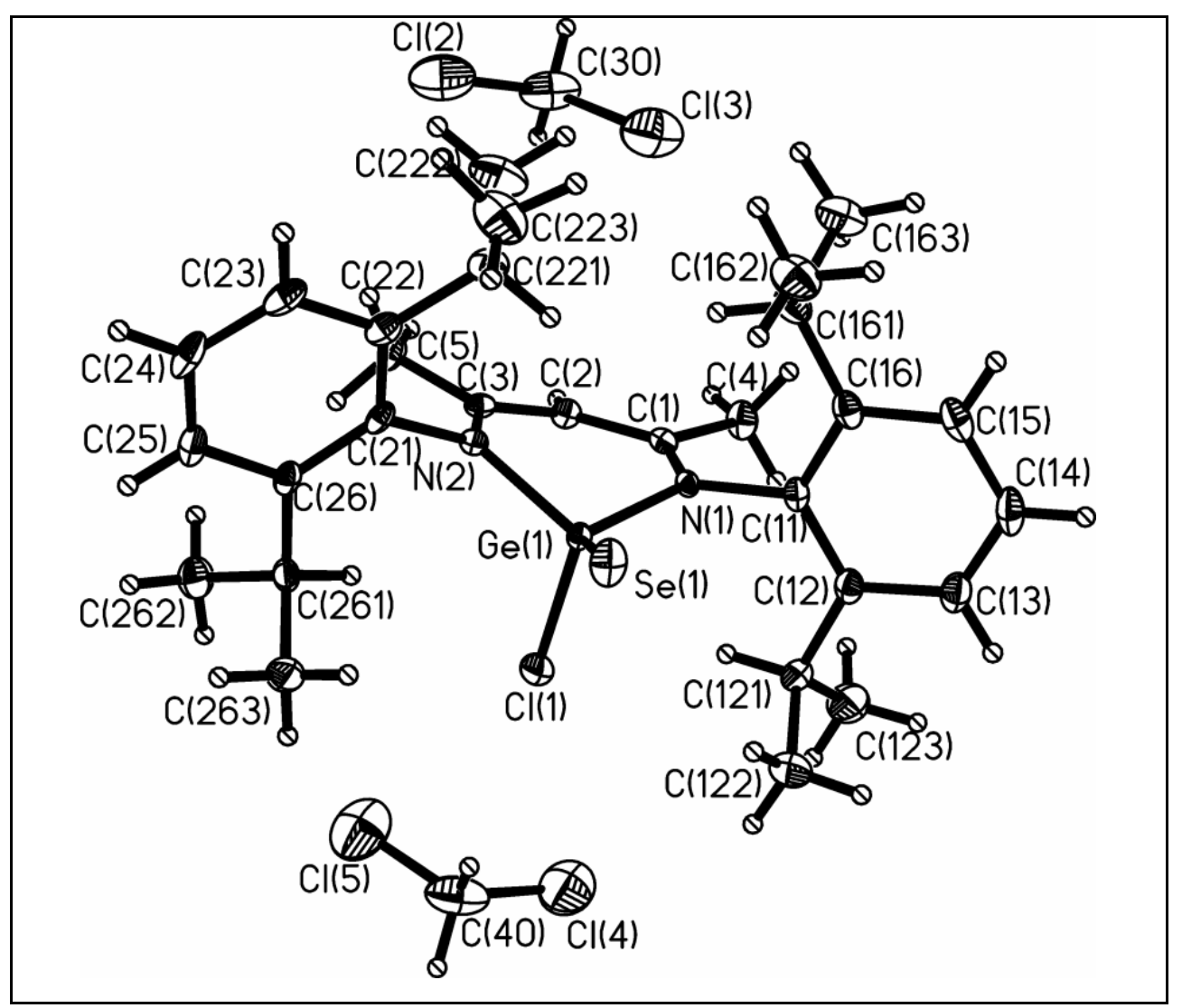

Figure 9. Molecular structure of $\mathbf{1 8}$ in the crystal (50\% probability thermal ellipsoids). Selected bond lengths ( $\AA$ ) and angles (deg): $\mathrm{Ge}(1)-\mathrm{Cl}(1) 2.164(8)$, $\mathrm{Ge}(1)-\mathrm{Se}(1)$ 2.197(6), Ge(1)-N(1) 1.900(2), Ge(1)-N(2) 1.901(2); Se(1)-Ge(1)$\mathrm{N}(1)$ 119.20(6), $\mathrm{Se}(1)-\mathrm{Ge}(1)-\mathrm{N}(2)$ 118.93(6), Se(1)-Ge(1)-Cl(1) 116.99(3), N(1) $-\mathrm{Ge}(1)-\mathrm{N}(2)$ 97.73(8), $\mathrm{Cl}(1)-\mathrm{Ge}(1)-\mathrm{N}(1)$ 100.04(7), Cl(1)-Ge(1)-N(2) 100.09(6).

The reactivity of $\mathbf{1 8}$ was preliminarily investigated using the alkylation reagent $n \mathrm{BuLi}$ (Scheme 8). Treatment of $\mathbf{1 8}$ with $n \mathrm{BuLi}$ in toluene at $-32{ }^{\circ} \mathrm{C}$ led to the formation of the alkylated compound $\left[\left\{\mathrm{HC}(\mathrm{CMeNAr})_{2}\right\} \mathrm{Ge}(\mathrm{Se}) n \mathrm{Bu}\right](\mathbf{2 0})$. Recrystallization of $\mathbf{2 0}$ from $n$ hexane toluene (1:5) at room temperature gave yellow crystals.

Compounds 18 - 20 were characterized by elemental analysis, EI-MS, and multinuclear NMR $\left({ }^{1} \mathrm{H},{ }^{19} \mathrm{~F},{ }^{77} \mathrm{Se}\right)$. All results are in accordance with the corresponding formulae. 


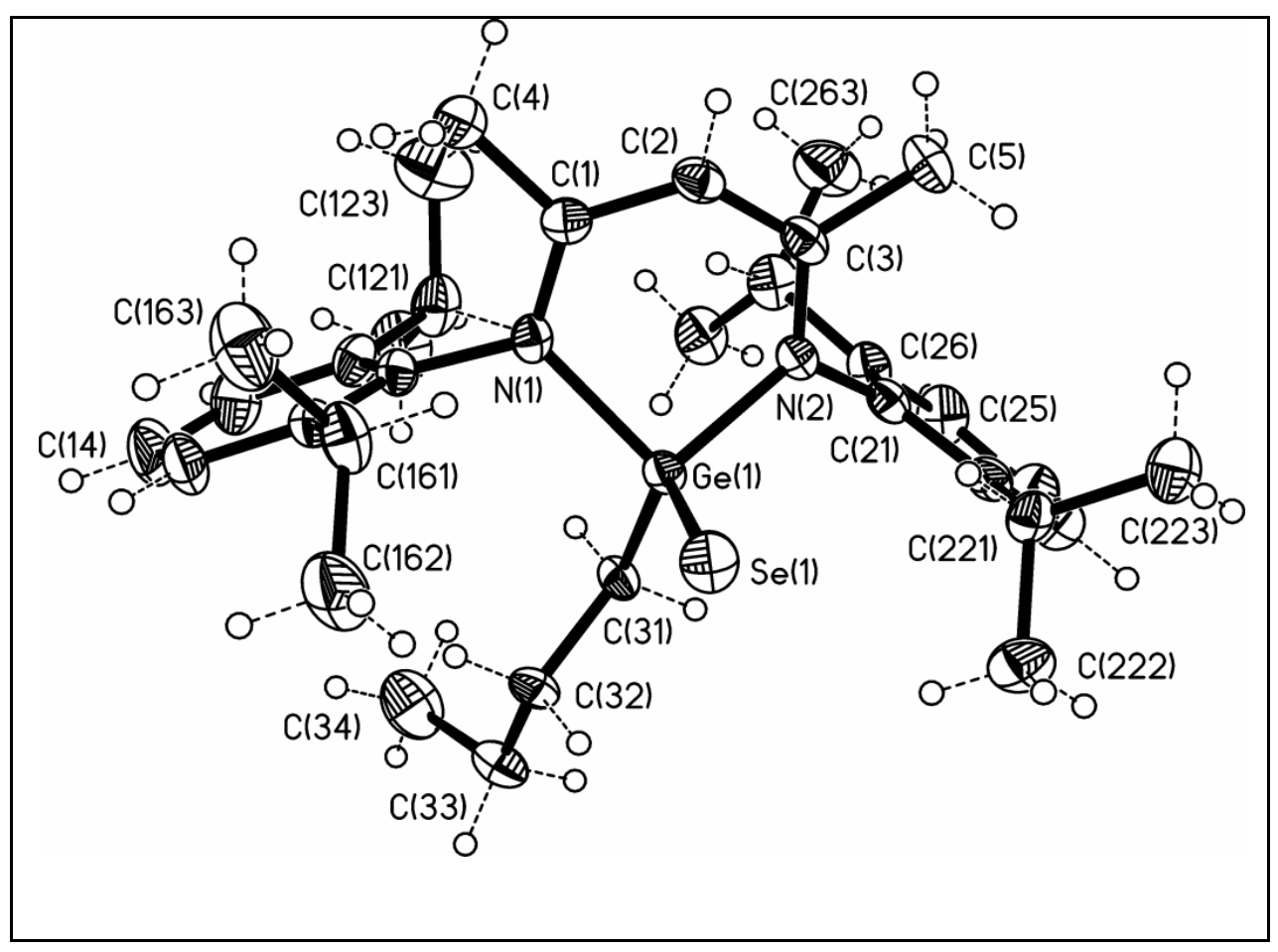

Figure 10. Molecular structure of 20 in the crystal (50\% probability thermal ellipsoids). Selected bond lengths (Å) and angles (deg): $G e(1)-C(31) 1.961(5)$, $\mathrm{Ge}(1)-\mathrm{Se}(1)$ 2.219(6), Ge(1)-N(1) 1.941(2), Ge(1)-N(2) 1.930(2); Se(1)-Ge(1)$\mathrm{N}(1)$ 111.55(7), Se(1)-Ge(1)-N(2) 112.08(7), Se(1)- Ge(1)-C(31) 120.95(14), $\mathrm{N}(1)-\mathrm{Ge}(1)-\mathrm{N}(2)$ 94.00(11), C(31)-Ge(1)-N(1) 106.52(17), C(31)-Ge(1)-N(2) 108.29(17).

The solid state structures of $\mathbf{1 8}$ and $\mathbf{2 0}$ were determined by single crystal X-ray diffraction. 18 crystallizes in the space group $P 2_{1} / c$ and 20 in the space group $P 2_{1} / n$. The structures of monomeric $\mathbf{1 8}$ and $\mathbf{2 0}$ are shown in Figures 9 and 10. Selected bond lengths and bond angles are given in the legends. The germanium centers adopt four coordinated geometries and reside in distorted tetrahedral environments. The geometries are similar to those of compounds 15 - 17.

The Ge-Se bond lengths (2.197(6) $\AA$ in 18, 2.219(6) $\AA$ in 20), which are shorter than the reported Ge-Se single bond length $(2.397(1) \AA),{ }^{21 f}$ are comparable to those $\left(2.247(7) \AA^{21 \mathrm{e}}\right.$ and 2.173(3) $\AA^{21 f}$ ) reported for Ge=Se. The Ge=Se bond length of 18 (2.197(6) $\AA$ ) is shorter than that of $\mathbf{2 0}(2.219(6) \AA$ ) due to the electron withdrawing affect of $\mathrm{Cl}$. This property also 
influences the Ge-N bond lengths (18 (1.900(1) and 1.901(2) $\AA)<20$ (1.941(2) and 1.930(2) $\AA$ ), as well as the $\mathrm{N}-\mathrm{Ge}-\mathrm{N}$ angles $(\mathbf{1 8}(97.73(8)>\mathbf{2 0}(90.00(11))$. The Ge-Cl bond length in 18 (2.164(8) $\AA$ ) is $0.131 \AA$ shorter than that in the starting material 3 (2.295(1) $\AA$ ) as expected from the higher oxidation state of the product.

\subsection{Synthesis, Structures, and Properties of $\left[\left\{\mathrm{HC}(\mathrm{CMeNAr})_{2}\right\} \mathrm{GeR}\right](\mathrm{Ar}=2,6-$ $\left.i \operatorname{Pr}_{2} \mathrm{C}_{6} \mathrm{H}_{3}, \mathrm{R}=\mathrm{Me}(21), n \mathrm{Bu}(22)\right)$ and the Resulting Derivatives $(23-25)$}

Compound $\mathbf{3}$ can be alkylated with alkyllithium reagents. Treatment of $\mathbf{3}$ with MeLi or with $n \mathrm{BuLi}$ in diethyl ether at $-78{ }^{\circ} \mathrm{C}$ afforded the alkylated germanium(II) compounds $\left[\mathrm{HC}(\mathrm{CMeNAr})_{2}\right] \mathrm{GeR}(\mathrm{R}=\mathrm{Me}(\mathbf{2 1}), n \mathrm{Bu}(\mathbf{2 2}))$ in high yields $(89 \%$ and $85 \%$, respectively) (Scheme 9). Crystals of $\mathbf{2 1}$ (red-orange) and 22 (deep red) suitable for single crystal X-ray analysis were obtained from their corresponding $n$ hexane solutions in a freezer at $-32{ }^{\circ} \mathrm{C}$.

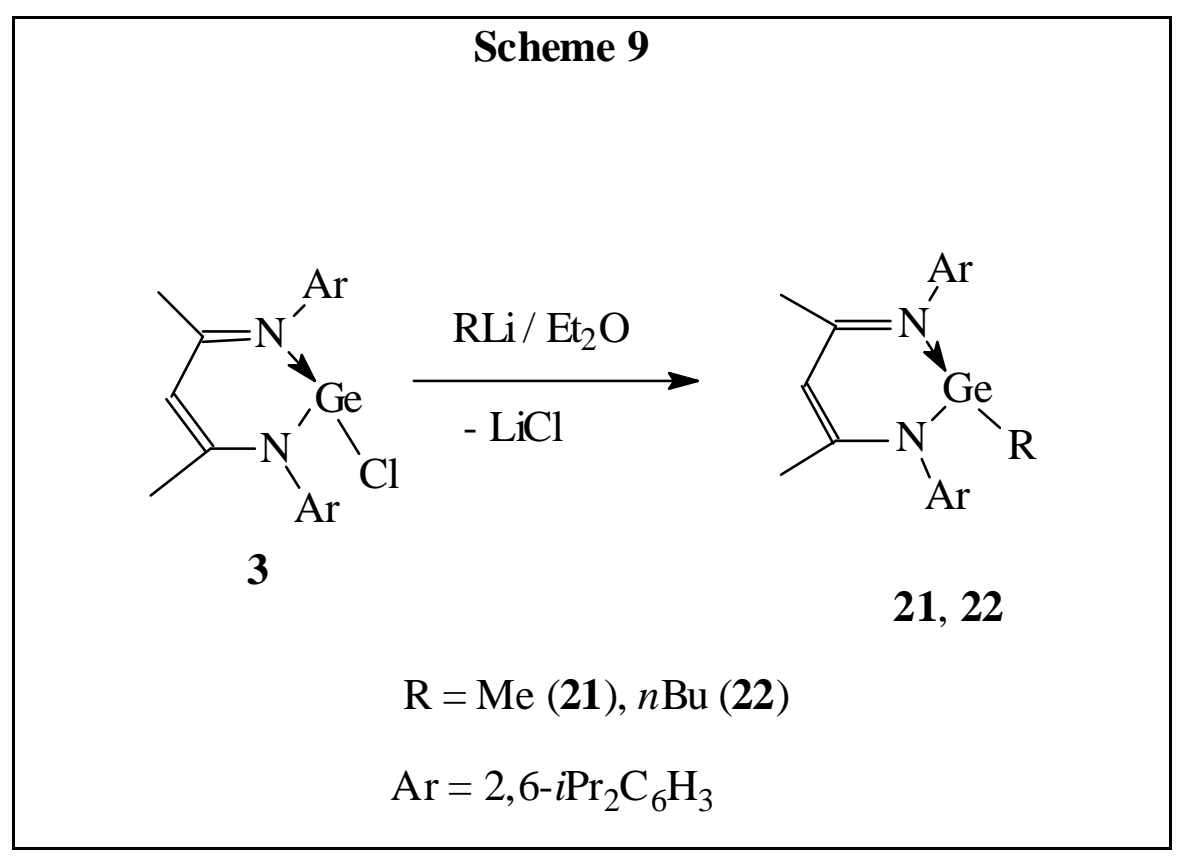

Compounds 21 and 22 have been fully characterized by elemental analyses, EI-MS and multinuclear NMR. In the ${ }^{1} \mathrm{H}$ NMR spectra the resonances of the methyl protons of the aryl substituents, which appear as doublets in the range of $\delta 1.12-1.46$, can be distinguished due to their different environments. The ${ }^{1} \mathrm{H}$ NMR resonances of $\mathrm{GeCH}_{3}$ for $\mathbf{2 1}(\delta 0.64 \mathrm{ppm})$ and 
of $\mathrm{Ge}\left(\mathrm{CH}_{2}\right)_{3} \mathrm{CH}_{3}$ for $22(\delta 0.80-1.05$ and $0.65 \mathrm{ppm})$ appear in the high field as expected due to the higher electron density of the germanium (II). The EI-MS spectra of 21 and 22 respectively give the corresponding molecular ion peak $\mathrm{M}^{+}$with the correct isotope patterns. Elemental analyses are also in accordance with the formulae.

Compounds 21 and 22 are robust under an inert atmosphere at temperatures below their melting points and possess excellent solubility in common organic solvents such as pentane, diethyl ether, and dichloromethane.

One feature of compounds $\mathbf{2 1}$ and $\mathbf{2 2}$ is their reactivity. First of all, we checked the oxidation behavior of compound 21 with chalcogens. Reflux of compound 21 with elemental sulfur in toluene led to the formation of the aforementioned (Scheme 7) compound 17 (Scheme 10). Similarly, the selenium analogue $\left[\left\{\mathrm{HC}(\mathrm{CMeNAr})_{2}\right\} \mathrm{Ge}(\mathrm{Me}) \mathrm{Se}\right](\mathbf{2 3})$ has been prepared at room temperature (Scheme 10) in a yield of $87 \%$.

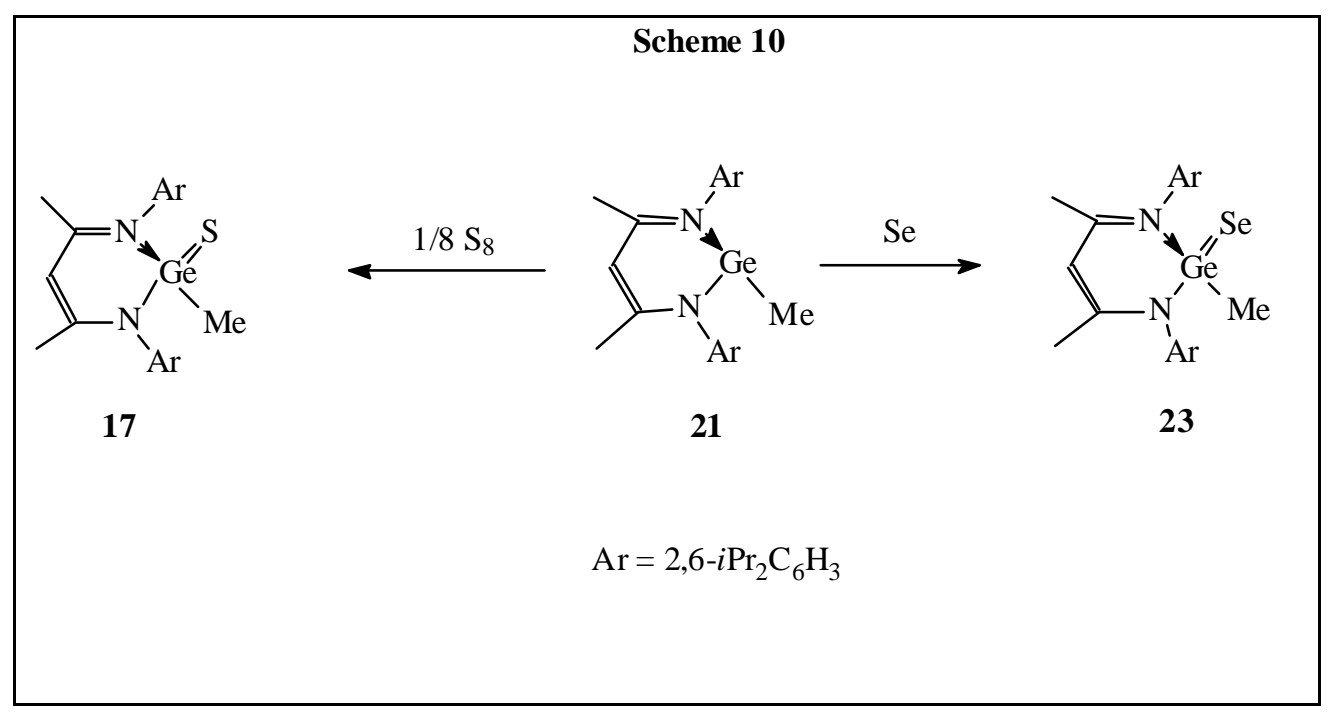

Both compounds $\mathbf{1 7}$ and $\mathbf{2 3}$ are well characterized by elemental analysis, EI-MS, and multinuclear NMR. The ${ }^{1} \mathrm{H}$ NMR resonances of $\mathrm{GeCH}_{3}$ for $\mathbf{1 7}(\delta 0.76 \mathrm{ppm})$ and for $\mathbf{2 3}(\delta$ $1.10 \mathrm{ppm})$ are shifted to lower field compared to the parent compound 21 ( $\delta 0.64 \mathrm{ppm})$ as expected due to the electron withdrawing effect of the chalcogens. The formation of $\mathbf{1 7}$ and $\mathbf{2 3}$ indicated that compounds $\mathbf{2 1}$ and $\mathbf{2 2}$ are likely good starting materials for the preparation of doubly bonded germanium species. 


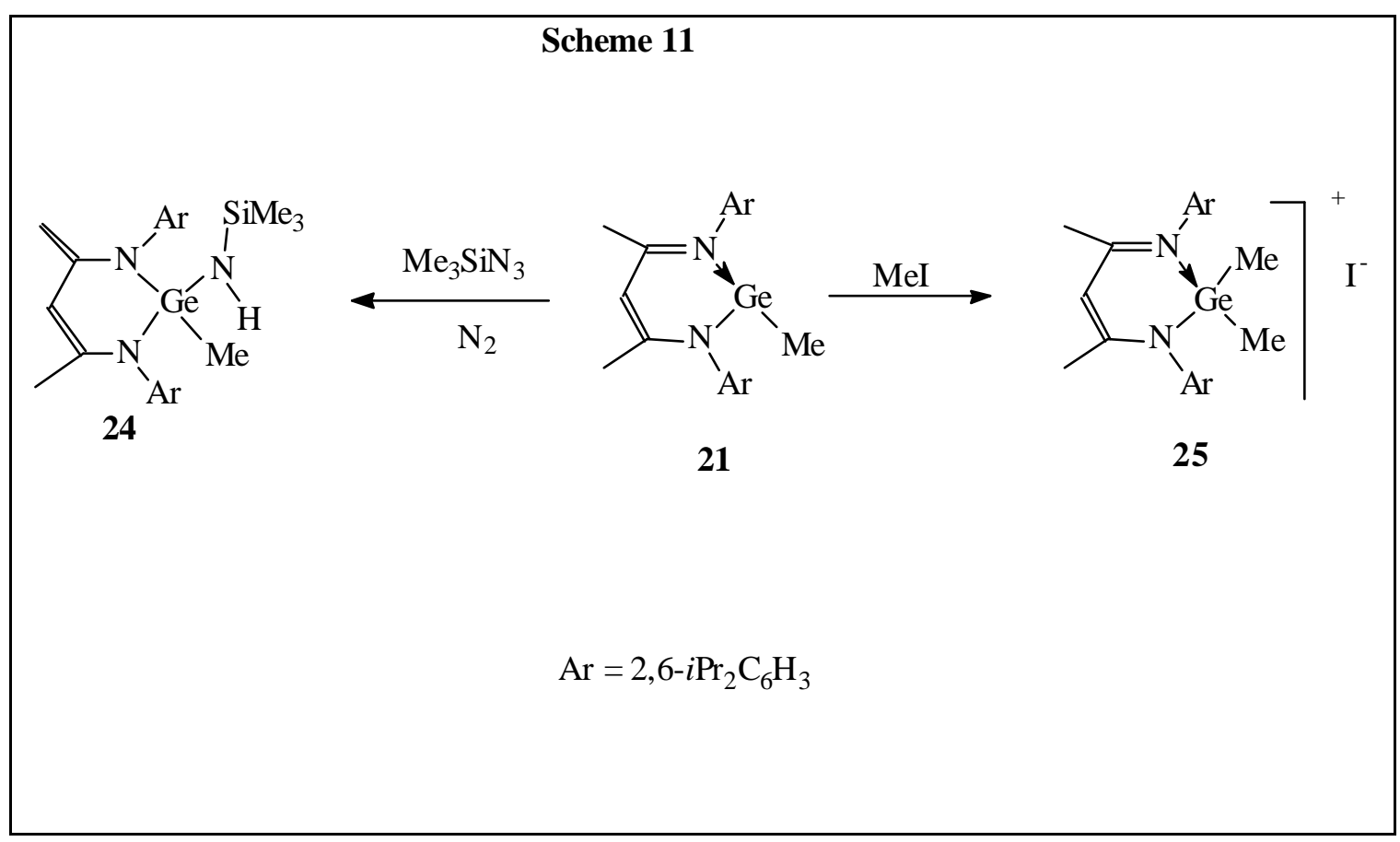

We preliminarily examined the reactivity of the lone pair electrons on the germanium of $\mathbf{2 1}$ with trimethylsilyl azide (Scheme 11). The reaction of germylenes with trimethylsilyl azide has been well studied and established as a route to compounds containing a $\mathrm{Ge}=\mathrm{N}$ double bond. ${ }^{29 b, 39 a, 44}$ However, treatment of $\mathbf{2 1}$ with trimethylsilyl azide in $n$ hexane at room temperature gave the singly bonded $\mathrm{Ge}-\mathrm{N}$ compound $\left[\left\{\mathrm{HC}\left(\mathrm{C}\left(\mathrm{CH}_{2}\right) \mathrm{NAr}\right) \mathrm{CMeNAr}\right\} \mathrm{Ge}(\mathrm{Me}) \mathrm{N}(\mathrm{H}) \mathrm{SiMe}_{3}\right]$ instead of $\left[\left\{\mathrm{HC}(\mathrm{CMeNAr})_{2}\right\} \mathrm{Ge}(\mathrm{Me}) \mathrm{NSiMe}_{3}\right.$. The reaction proceeds with migration of a hydrogen atom from a methyl group of the ligand backbone to the nitrogen atom at silicon with formation of a methylene group. Compound $\mathbf{2 4}$ was characterized by elemental analyses, EI-MS, multinuclear $\left({ }^{1} \mathrm{H},{ }^{29} \mathrm{Si}\right) \mathrm{NMR}$, and IR. The EI-MS spectra shows the molecular ion peak $\mathrm{M}^{+}$ (593) in agreement with the calculated isotope pattern. In the ${ }^{1} \mathrm{H}$ NMR spectrum of $\mathbf{2 4}$ (toluene- $\left.d_{8}\right)$ the resonances clearly show the existence of $\mathrm{NH}(\delta 0.25 \mathrm{ppm}, \mathrm{br}, 1 \mathrm{H})$ and the $\beta-\mathrm{CH}_{2}$ moiety $(\delta 3.22 \mathrm{ppm}$, br, $1 \mathrm{H}$ and $\delta 3.86 \mathrm{ppm}$, br, $1 \mathrm{H}$ ). The IR NH absorption is observed at $v=3361 \mathrm{~cm}^{-1}$. The $\mathrm{NH}$ resonance as well as the IR stretching frequency are comparable with those of other germanium compounds bearing a $\mathrm{N}(\mathrm{H}) \mathrm{SiMe}_{3}$ groups. $^{44}$ 
Although the mechanism for the formation of $\mathbf{2 4}$ is unclear, the most likely one is given in Scheme 12.

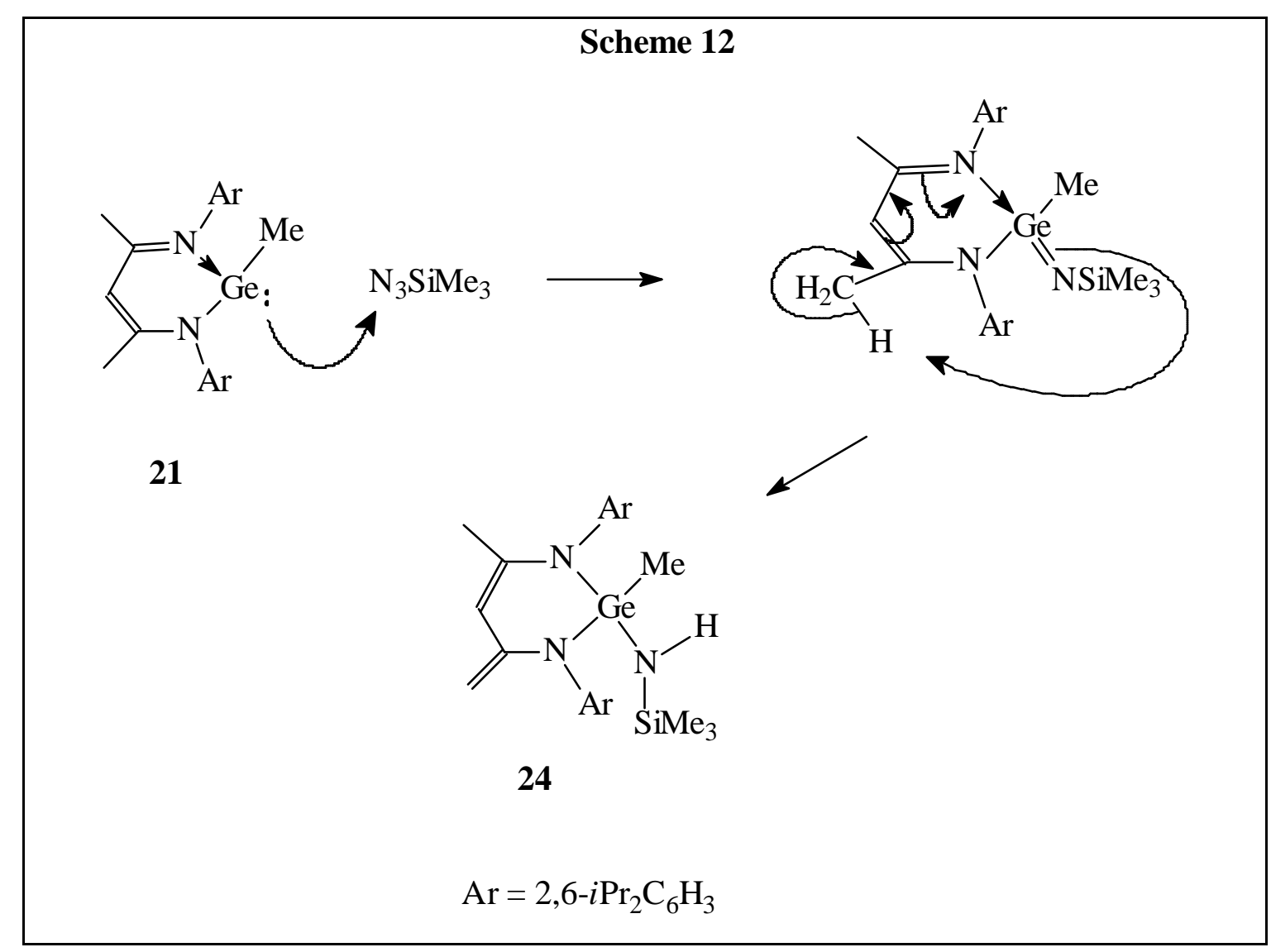

The oxidative addition reaction of $\mathbf{2 1}$ with MeI in dichloromethane afforded the ionic compound $\left[\left\{\mathrm{HC}(\mathrm{CMeNAr})_{2}\right\} \mathrm{GeMe}_{2}\right]^{+} \mathrm{I}^{-}$(25) (Scheme 11). Compound 25 has a poor solubility in THF and a high melting point $\left(217-219^{\circ} \mathrm{C}\right)$ compared to the starting material 21 due to its ionic character. A comparable behavior has been reported previously. ${ }^{25}$ Compound 25 was characterized by ${ }^{1} \mathrm{H}$ NMR, EI-MS, and elemental analysis. 


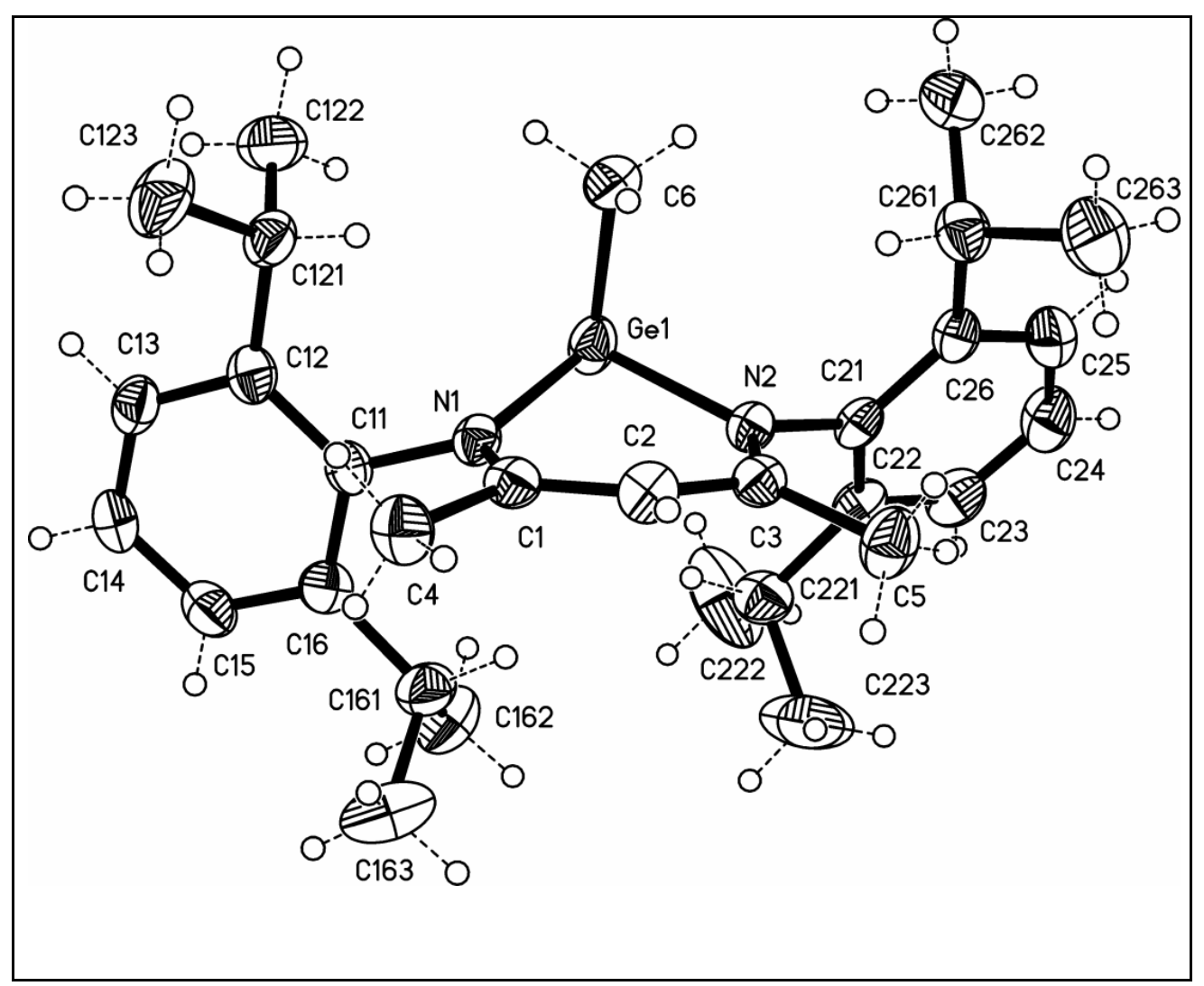

Figure 11. Molecular structure of $\mathbf{2 1}$ in the crystal (50\% probability thermal ellipsoids). Selected bond lengths ( $\AA$ ) and angles (deg): $G e(1)-C(6) 2.002(4)$, $\mathrm{Ge}(1)-\mathrm{N}(1)$ 2.008(2), $\mathrm{Ge}(1)-\mathrm{N}(2)$ 2.038(2); N(1)-Ge(1)-N(2) 90.87(9), C(6)$\mathrm{Ge}(1)-\mathrm{N}(1)$ 97.13(13), C(6)-Ge(1)-N(2) 92.81(12).

The solid-state structures of compounds 21 and 22 were determined by single crystal X-ray diffraction and are shown in Figures 11 and 12 with selected bond lengths and angles. The structures show that both compounds are monomeric and the germanium centers adopt similar three-coordinated sites. The sum of the bond angles at the germanium centers $\left(280.81^{\circ}\right.$ in 21 and $285.44^{\circ}$ in 22) deviates strongly from the $\mathrm{sp}^{3}$ tetrahedron. Thus, the geometry of $\mathbf{2 1}$ and 22 may be described as trigonal pyramidal rather than as distorted tetrahedral. The Ge-N bond lengths in $21(2.008(2)$ and 2.038(2) $\AA$ ) and in $22(2.023(2)$ and 2.025(2) $\AA$ ) are similar and in the normal range, ${ }^{29 a, b, 39 a, 44}$ but little longer than those of the starting material 3 (1.988(2) and 1.997(3) ̊). Obviously, this results from the influence of the substituents at the metal center (the stronger electron withdrawing effect of chlorine compared to the alkyl 
groups). The Ge-C bond length in 21 (2.002(4) $\AA$ ) and in $22(2.014(2) \AA)$ is in the normal range (1.962(6) to $2.039(3) \AA)^{25}$

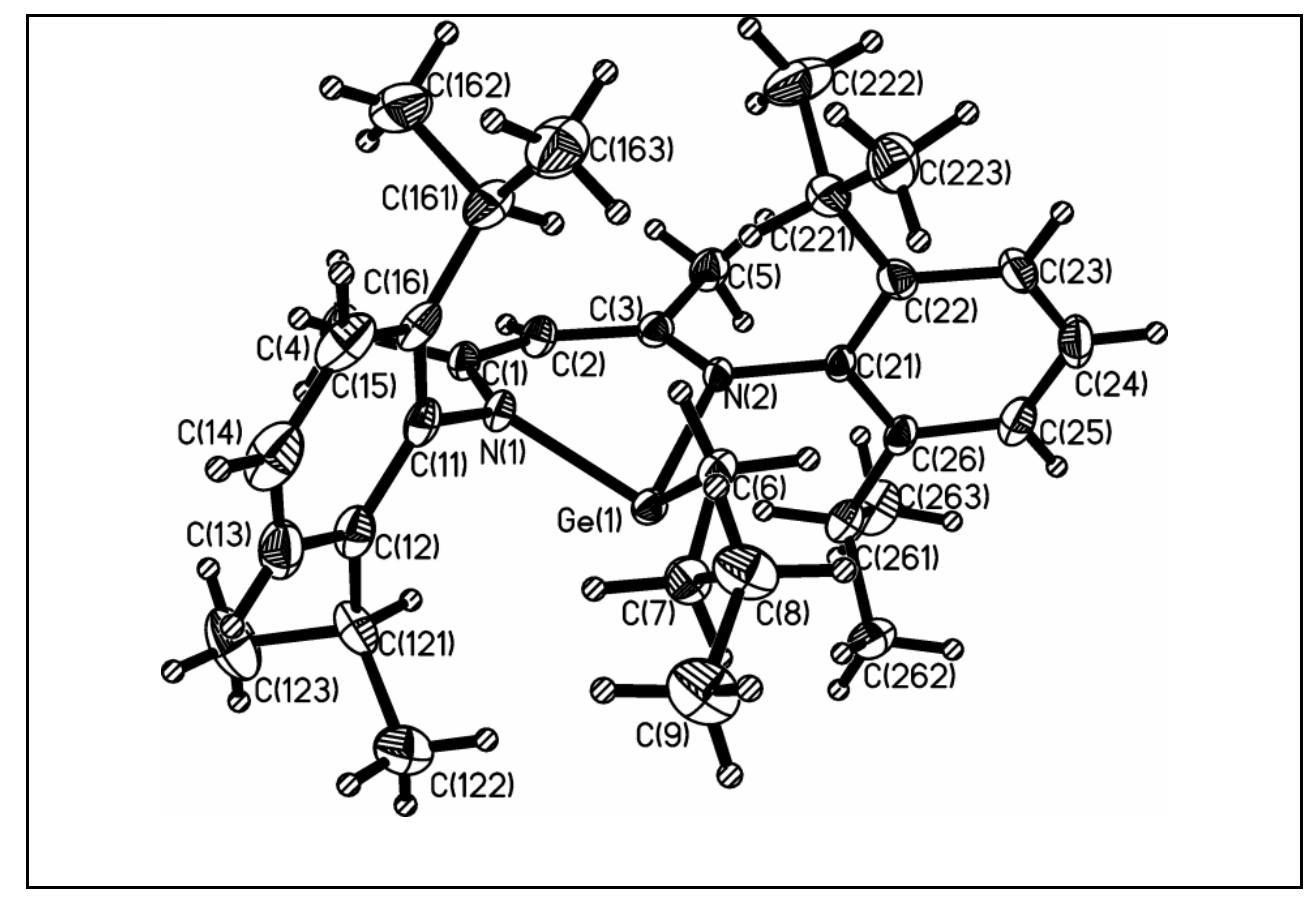

Figure 12. Molecular structure of 22 in the crystal (50\% probability thermal ellipsoids). Selected bond lengths $(\AA ̊)$ and angles (deg): $\mathrm{Ge}(1)-C(6) 2.014(2)$, $\mathrm{Ge}(1)-\mathrm{N}(1)$ 2.023(2), $\mathrm{Ge}(1)-\mathrm{N}(2)$ 2.025(2); N(1)-Ge(1)-N(2) 87.86(9), C(6)$\mathrm{Ge}(1)-\mathrm{N}(1)$ 97.52(9), C(6)-Ge(1)-N(2)100.06(9).

Figure 13 shows that compound $\mathbf{2 3}$ is monomeric. The germanium center adopts a four coordinated site and resides in a distorted tetrahedral environment. This geometry is similar to that of its sulfur analogue and to those of the compounds containing a terminal chalcogenido germanium unit. $^{21 \mathrm{a}, \mathrm{d}-\mathrm{f}}$ The observed Ge-Se bond length in 23 (2.199(6) $\AA$ ), which is shorter than the reported Ge-Se single bond length (2.397(1) and 2.433(1) $\AA$ ), ${ }^{21 \mathrm{f}}$ is in agreement with those $\left(2.180(2){ }^{21 \mathrm{f}}\right.$ to $2.247(7) \AA^{21 \mathrm{e}}$ ) reported for Ge=Se. In compound 23, the bond lengths of $\mathrm{Ge}-\mathrm{N}(1.931(2)$ and 1.947(2) $\AA$ ) and Ge-C (1.973(2) $\AA$ ) are shorter than those of the starting material $21(\mathrm{Ge}(1)-\mathrm{N}(1) \quad 2.008(2), \mathrm{Ge}(1)-\mathrm{N}(2) \quad 2.038(2)$, and $\mathrm{Ge}(1)-\mathrm{C}(6)$ $2.002(4) \AA$ ) as expected from the higher oxidation state of the product, so is the $\mathrm{N}(1)-\mathrm{Ge}(1)-\mathrm{N}(2)$ angle of $\mathbf{2 3}\left(95.24(8)^{\circ}\right)$ larger than that of $21\left(90.87(8)^{\circ}\right)$. 


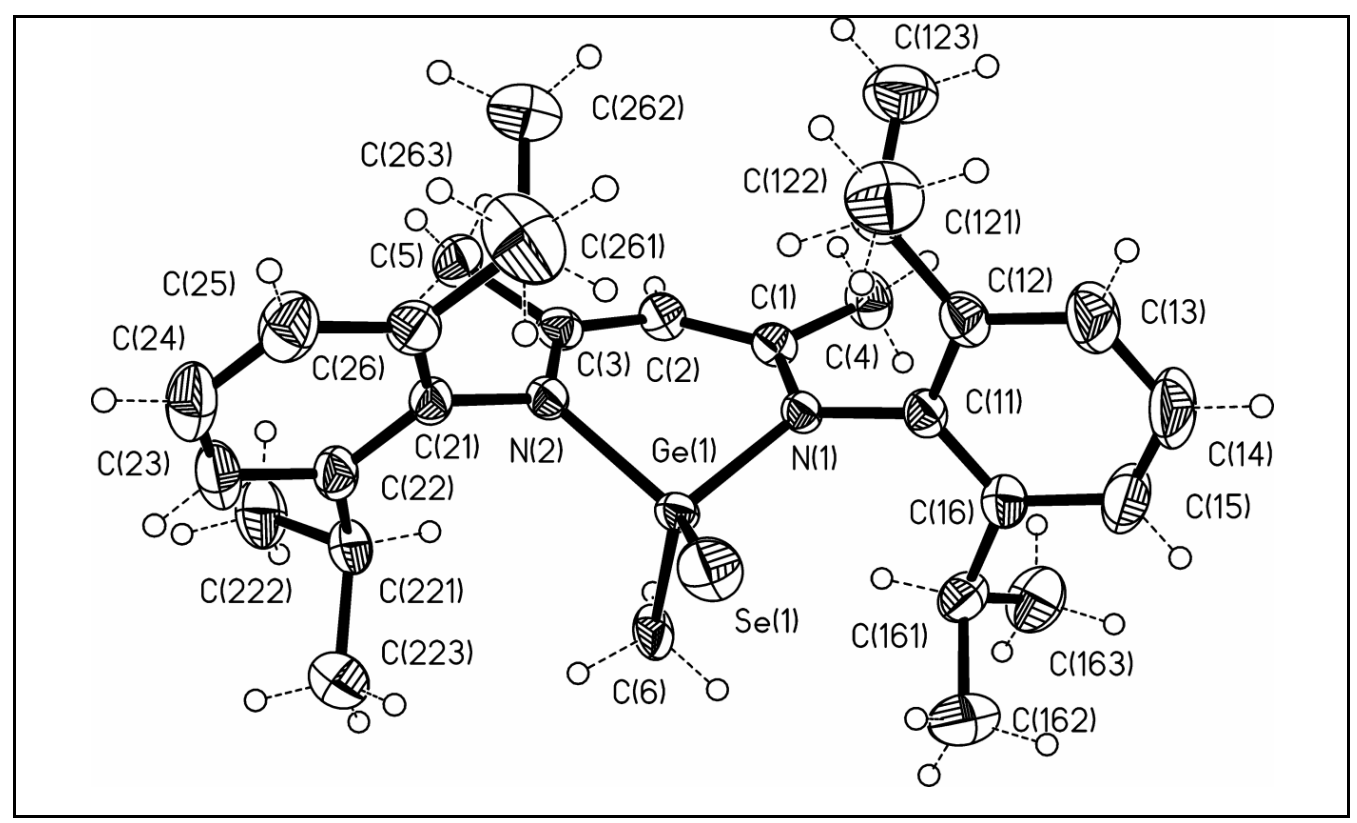

Figure 13. Molecular structure of 23 in the crystal (50\% probability thermal ellipsoids). Selected bond lengths (Å) and angles (deg): $\mathrm{Ge}(1)-C(6)$ 1.973(2), $\mathrm{Ge}(1)-\mathrm{Se}(1)$ 2.199(6), Ge(1)-N(1) 1.931(2), Ge(1)-N(2) 1.947(2); Se(1)-Ge(1)$\mathrm{N}(1)$ 113.38(6), Se(1)-Ge(1)-N(2) 117.15(6), Se(1)-Ge(1)-C(6) 120.94(10, N(1) $-\mathrm{Ge}(1)-\mathrm{N}(2) \quad 95.24(8), \quad \mathrm{C}(6)-\mathrm{Ge}(1)-\mathrm{N}(1) \quad$ 103.64(11), $\quad \mathrm{C}(6)-\mathrm{Ge}(1)-\mathrm{N}(2)$ 102.70(10).

Pale yellow crystals of $\mathbf{2 4}$ were obtained from a $n$ hexane solution at $-32{ }^{\circ} \mathrm{C}$ and investigated by X-ray diffraction analysis. The molecule lies on a crystallographic mirror plane although only parts of the structure fulfil this symmetry. Refinement in the lower symmetric space group $P 2_{1}$ shows the same disorder and no improvement. Due to this disorder the affected bond lengths are not very accurate. Nevertheless, some structural informations of $\mathbf{2 4}$ were obtained. Crystallographic data of $\mathbf{2 4}$ are listed in Section 6. The molecular backbone of $\mathbf{2 4}$ is shown in Figure 14. The structure shows compound $\mathbf{2 4}$ is monomeric in the solid state and the germanium center has a coordination number of 4. Although the bond lengths should be discussed carefully, it becomes clear that they are different compared to those of structure 23. The Ge-N bonds are in the range of 1.8 to $1.9 \AA$ (1.931(2) and 1.947(2) in 
23), while the $\mathrm{N}-\mathrm{C}$ bond is elongated (1.393(2) $\AA$ in 24 and 1.347(3) and 1.338(3) in 23). The hydrogen bond to N3 could clearly be found in the electron density map. These findings, as well as the results of the NMR, IR, EI-MS, and elemental analysis, are all in accordance with the formula of $\mathbf{2 4}$.

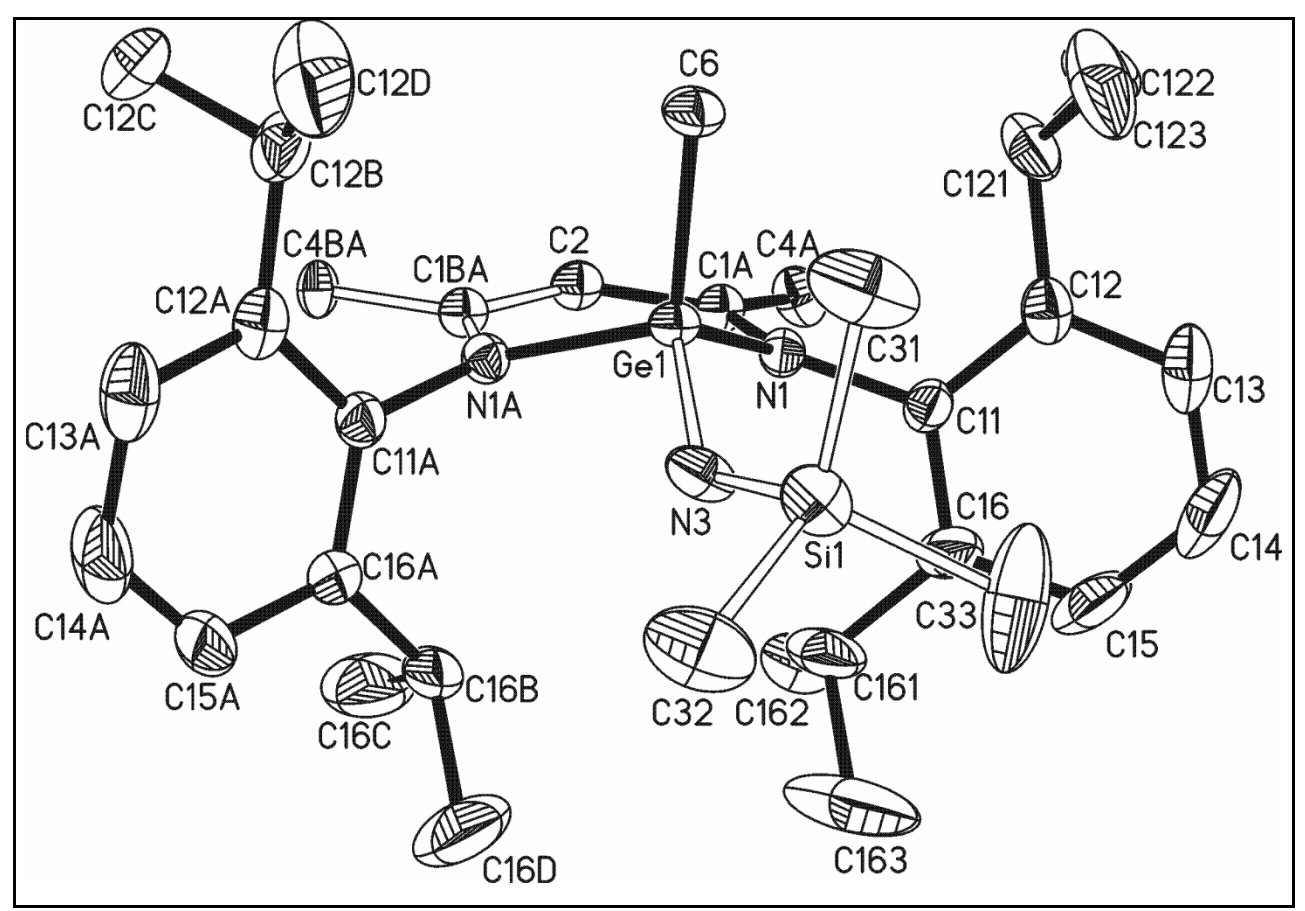

The molecular backbone of $\mathbf{2 4}$

\subsection{Synthesis and Structures of Divalent Tin Compounds of Type $\operatorname{Sn}(X) R(26-29)$}

Organotin(IV) hydrides generally can be prepared by the reduction of the corresponding chlorides with $\mathrm{LiAlH}_{4}{ }^{45}$ However, treatment of $\left[\left\{\mathrm{HC}(\mathrm{CMeNAr})_{2}\right\} \mathrm{SnCl}\right](\mathbf{5})$ with $\mathrm{LiAlH}_{4}$ in diethyl ether at room temperature did not give $\left[\left\{\mathrm{HC}(\mathrm{CMeNAr})_{2}\right\} \mathrm{SnH}\right]$, instead the known aluminum hydride $\left[\left\{\mathrm{HC}(\mathrm{CMeNAr})_{2}\right\} \mathrm{AlH}_{2}\right]^{37}$ (Scheme 13) was formed. Further attempts to prepare $\left[\left\{\mathrm{HC}(\mathrm{CMeNAr})_{2}\right\} \mathrm{SnH}\right]$ by reduction of $\mathbf{5}$ with various other reducing agents, including $\mathrm{NaBH}_{4}, \mathrm{KBH}_{4}, \mathrm{KH}$, and $\mathrm{NaH}$, were not successful. The reduction of complex 5 with $\mathrm{C}_{8} \mathrm{~K}$ unexpectedly resulted in the formation of $\left[\left\{\mathrm{HC}(\mathrm{CMeNAr})_{2}\right\}_{2} \mathrm{Sn}\right](\mathbf{2 6})$ in low yield and a significant amount of in metal (Scheme 13). No other reduced species could be isolated. 


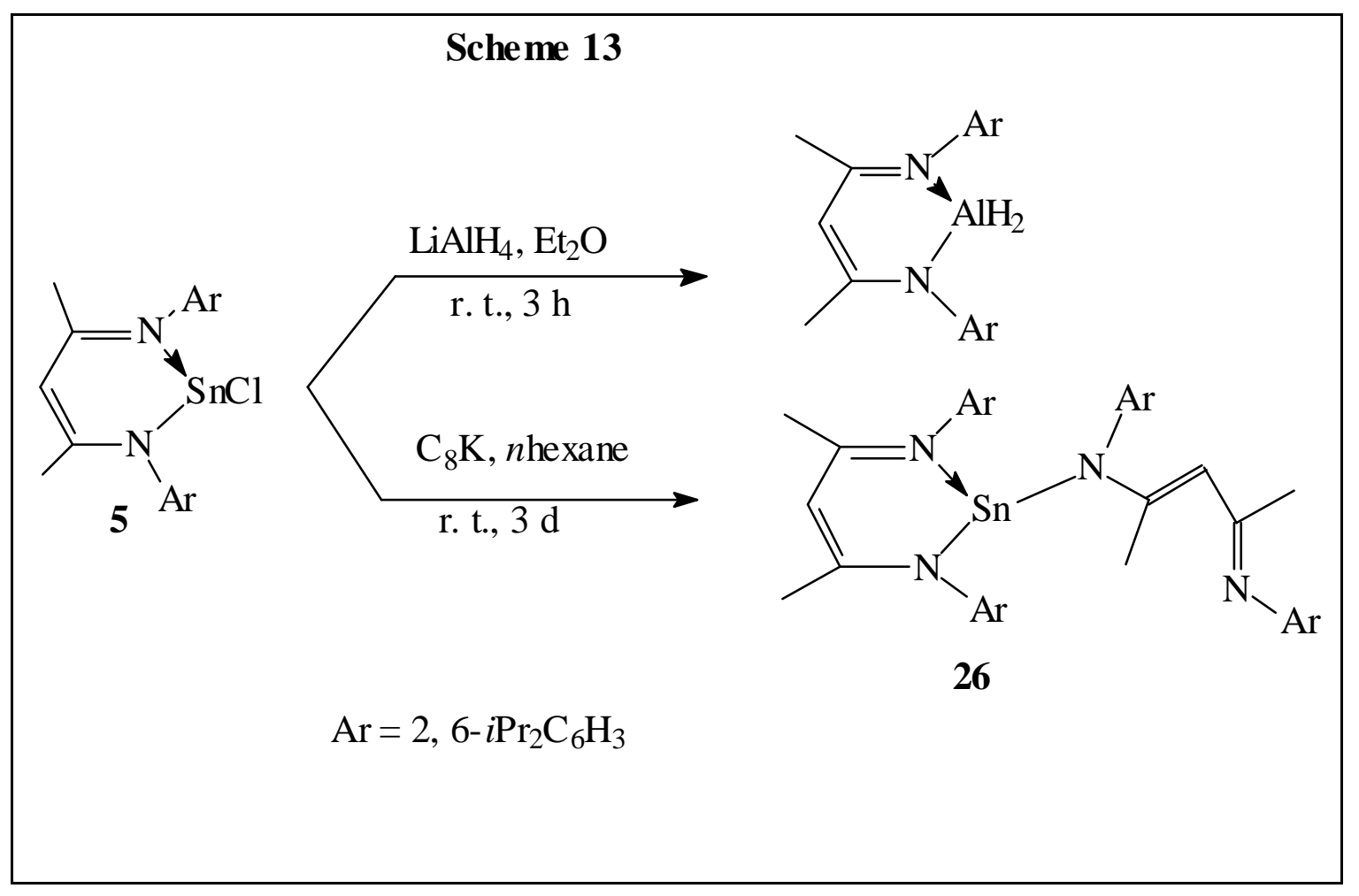

Furthermore, we examined substitution reactions of $\mathbf{5}$ with selected nucleophiles in order to prepare tin(II) derivatives. Treatment of 5 with $t \mathrm{BuLi}, \mathrm{AgSO}_{3} \mathrm{CF}_{3}$ and $\mathrm{NaN}_{3}$ resulted in the formation of $\left[\left\{\mathrm{HC}(\mathrm{CMeNAr})_{2}\right\} \mathrm{SnX}\right]\left(\mathrm{X}=t \mathrm{Bu}(\mathbf{2 7}), \mathrm{CF}_{3} \mathrm{SO}_{3}(\mathbf{2 8}), \mathrm{N}_{3}\right.$ (29) respectively) (Scheme 14). The addition of $t$ BuLi to $\mathbf{5}$ in $n$ hexane at low temperature provided 27 in high yield. The triflate anion $\left(\mathrm{SO}_{3} \mathrm{CF}_{3}\right)$ has been recognized as an excellent leaving group in nucleophilic displacement reactions. ${ }^{46}$ Organotin triflates may act as precursors for further reactions. $\mathrm{LSn}\left(\mathrm{OSO}_{2} \mathrm{CF}_{3}\right)(\mathbf{2 8})$ was prepared in toluene in high yield as colorless crystals which are soluble in common organic solvents, such as $n$ hexane and toluene. Metal and nonmetal species containing the azide functionality are of interest as starting materials and the tin(IV) azides are well established. ${ }^{47}$ However, to our knowledge, the only example of a tin(II) azide, [( $\left.n \mathrm{Pr})_{2} \mathrm{ATI}\right] \mathrm{SnN}_{3}$, was reported only recently. ${ }^{26 e}$ The azide compound 29 was readily prepared as light-yellow crystals by the reaction of $\mathbf{5}$ with $\mathrm{NaN}_{3}$ in THF at room temperature in high yield. 


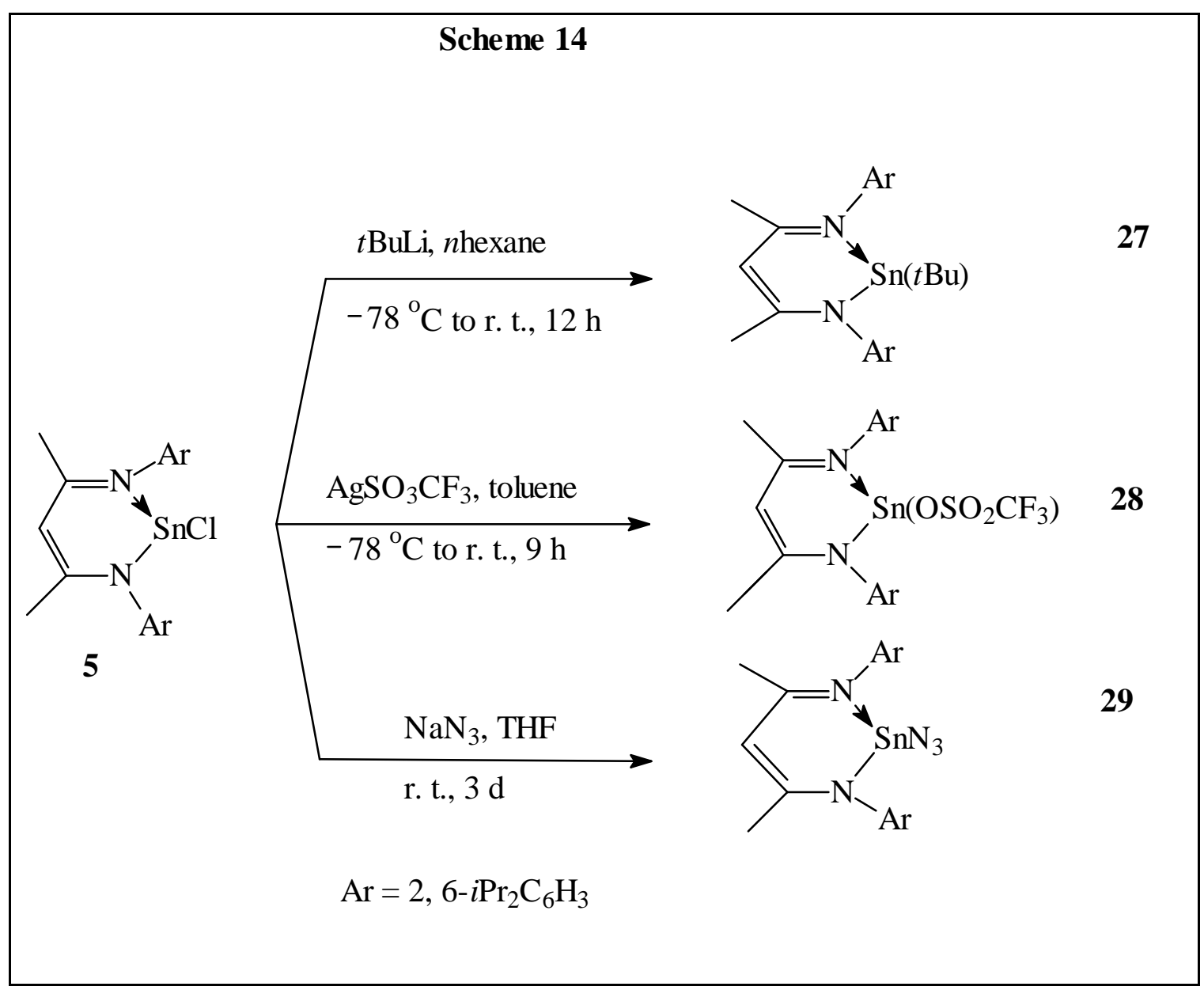

Compounds 26 - 29 were fully characterized by elemental analyses, EI-MS and multinuclear NMR. In the ${ }^{1} \mathrm{H}$ NMR spectra, the resonances of the methyl protons of the aryl substituents, which appear as doublets in the range of $\delta 1.01-1.58 \mathrm{ppm}$, could be distinguished due to their different environments. However, the ${ }^{1} \mathrm{H}$ NMR signals of 26 overlapped in the range of $\delta 0.88-3.44$ ppm because of the multiple chemical environments of their protons as shown in the solid state structure. The ${ }^{119} \mathrm{Sn}$ NMR spectra of $\mathbf{5}$ and $\mathbf{2 6}$ 29 are comparable with those of tin(II) poly(1-pyrazolyl)borates in which the metal centers reside in a similar environment. ${ }^{119} \mathrm{Sn}$ NMR spectroscopy was found to be a useful probe for the determination of the coordination of tin(II) in poly(1-pyrazolyl)borates whose ${ }^{119} \mathrm{Sn}$ chemical shifts vary with the coordination numbers: $(\delta-730$ to -950 for six-, -650 to -730 for four-, and -270 to $-350 \mathrm{ppm}$ for three-coordinated Sn, respectively). ${ }^{34}$ For compounds $\mathbf{5}, \mathbf{2 6}$, and 28 , in which the tin is three-coordinated in the solid state, the ${ }^{119} \mathrm{Sn}$ NMR chemical shifts are in the range $\delta-224$ to $-246 \mathrm{ppm}$. Although the coordination numbers of the metal 
center in solution may be different from those in the solid state, comparing these chemical shifts with those of the tin(II) poly(1-pyrazolyl)borates, the tin atoms in compounds $\mathbf{5}, \mathbf{2 6}$, and $\mathbf{2 8}$, as well as $29\left({ }^{119} \mathrm{Sn} \mathrm{NMR}\right.$ : $\left.\delta-237 \mathrm{ppm}\right)$ are probably three-coordinated in solution as well. The ${ }^{119} \mathrm{Sn}$ NMR resonance of the $t$ butyl derivative 27 is found at low field ( $\delta 259 \mathrm{ppm}$ ), suggesting that the tin atom in $\mathbf{2 7}$ may be two-coordinated in solution. The EI-MS spectrum of $\mathbf{2 8}$ gives the correct molecular ion peak $\mathrm{M}^{+}$.

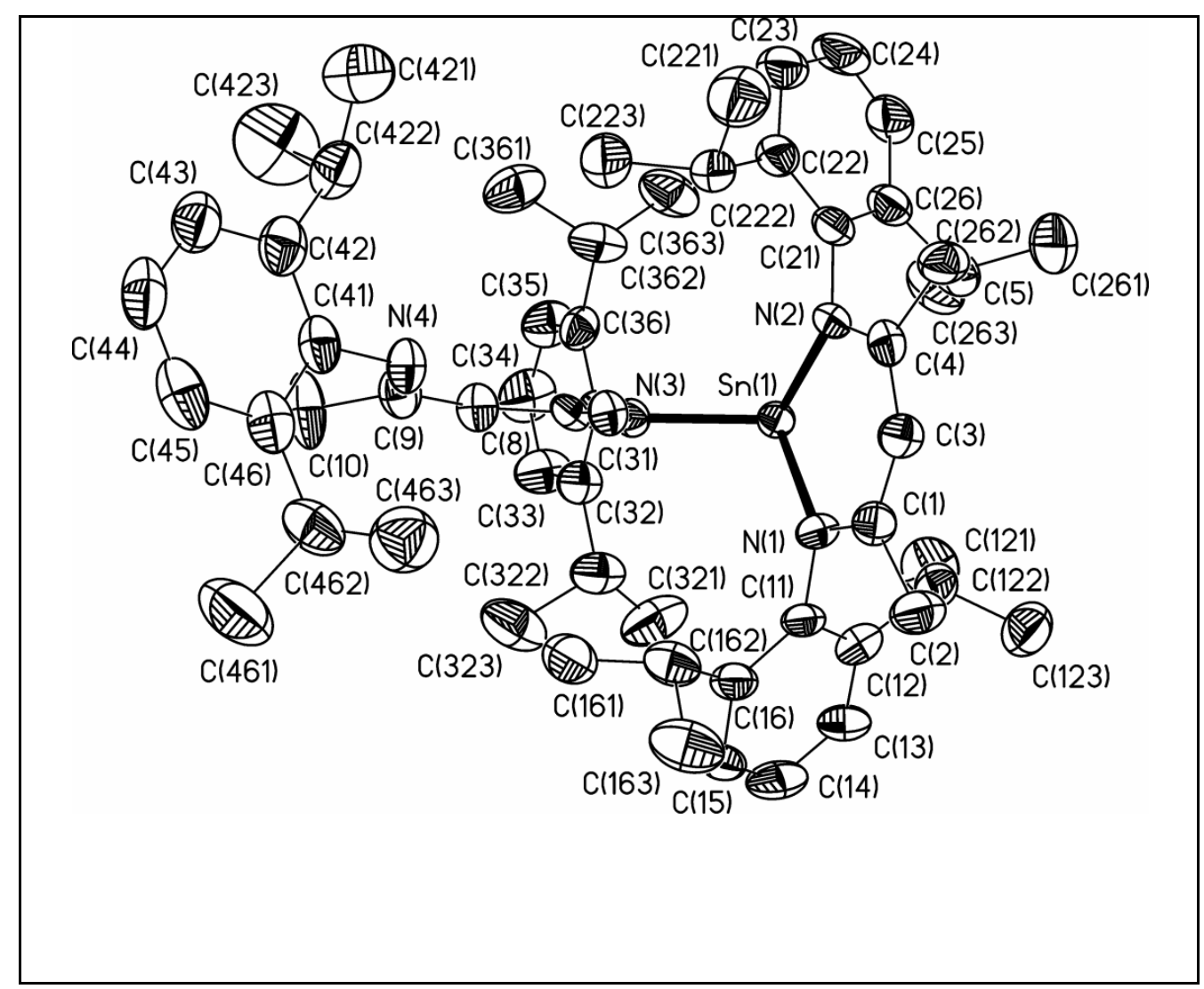

Figure 15. Molecular structure of 26 in the crystal (50\% probability thermal ellipsoids, $H$ atoms not shown for clarity). Selected bond lengths $(\AA)$ and angles (deg): $\operatorname{Sn}(1)-N(1)$ 2.235(6), Sn(1)-N(2) 2.251(6), Sn(1)-N(3) 2.166(6), C(1)-N(1) 1.341(10), $\quad \mathrm{C}(4)-\mathrm{N}(2) \quad 1.330(10) ; \mathrm{N}(3)-\mathrm{Sn}(1)-\mathrm{N}(1)$ 102.7(2), N(3)-Sn(1)-N(2) 106.8(2), N(1)-Sn(1)-N(2) 85.2(2).

The solid-state structures of compounds $\mathbf{2 6}$ and $\mathbf{2 8}$ as determined by single crystal X-ray diffraction are shown in Figures 15 and 16 with selected bond lengths and angles. They show 
that both compounds are monomeric. The metal centers adopt similar three-coordinated sites and reside in distorted tetrahedral environments with one vertex occupied by a lone pair of electrons.

The structural features of the divalent compounds $\mathbf{2 6}$ and $\mathbf{2 8}$, like compounds $\mathbf{3}$ and $\mathbf{5}$, are also different from those of the comparable tetravalent $\mathrm{SnCl}(\mathrm{Me})_{2}\left[\mathrm{CH}(\mathrm{CPhNSiMe})_{2}\right](8)$ and $\mathrm{SnCl}(\mathrm{Me})_{2}\left[\mathrm{CH}(\mathrm{CPhNH})_{2}\right](\mathbf{9}){ }^{36}$ In compounds 26 and 28 the backbone of the chelating ligand is essentially planar and the metal atom is always out of the plane $(0.24 \AA$ in $\mathbf{2 6}$, and $0.65 \AA$ in 28 ). The differences of the two bond lengths from the metal center to the chelating nitrogen atoms in the compounds $\mathbf{2 6}$ and $\mathbf{2 8}$ ranges from 0.003 to $0.019 \AA$. However, the comparable ones in $\mathbf{8}$ and in $\mathbf{9}(0.201 \AA$ in $\mathbf{8}$ and $0.109 \AA$ in 9) are significantly longer.

The observed Sn-N bond lengths in 26 (2.235(6), 2.251(6), and 2.166(6) $\AA$ ) and in 28 $\left(2.142(3)\right.$ and $2.139 \AA$ ) are in the normal range $\left(2.121-2.397 \AA\right.$ for $\mathrm{Sn}-\mathrm{N}$ single bonds $\left.{ }^{34}\right)$. The structure of $\mathbf{2 6}$ shows that one ligand is chelated to tin, while the other is monodentate. This is a result of the steric demand of the two ligands. In compound 26, the $\mathrm{Sn}-\mathrm{N}$ bond distances of the chelating nitrogen atoms (2.233(6) and 2.251(6) $\AA$ ) are longer than that of the monodentate ligand (2.166(6) $\AA$ ), as well as those in $\mathbf{5}$ and $28(2.139(3)-2.185(2) \AA)$.

A noteworthy feature of metal triflates is the diversity of bonding modes, ranging from ionic to mono-, bi- or tridentate, terminal or bridging. ${ }^{28}$ For tin(II) triflate, a weakly coordinating ionic compound $\mathrm{Sn}\left(\mathrm{CF}_{3} \mathrm{SO}_{3}\right)\left[\mathrm{HB}\left\{3,5-\left(\mathrm{CF}_{3}\right)_{2} \mathrm{Pz}\right\}_{3}\right]$ (30) was reported by Dias ${ }^{48}$ and a bidentate compound $\left[\mathrm{Sn}\left(\eta^{2}-\mathrm{CF}_{3} \mathrm{SO}_{3}\right)\left\{\mathrm{N}\left(\mathrm{SiMe}_{3}\right)_{2}\right\}\right]_{2}$ (31) by Lappert et al. ${ }^{28}$ In compound 28, (Figure 16) the triflate group is monodentate. The $\mathrm{Sn}(1)-\mathrm{O}(1)$ distance $(2.254(2) \AA)$ in $\mathbf{2 8}$ is shorter than those in $\mathbf{3 0}(2.507(3) \AA)^{48}$ and in $\mathbf{3 1}(2.291(4)$ and $2.489(4) \AA){ }^{28}$ This closer contact of the triflate moiety with the metal center in $\mathbf{2 8}$ than those in $\mathbf{3 0}$ and $\mathbf{3 1}$ is probably caused by the differences of the coordination environments of the metal centers. 


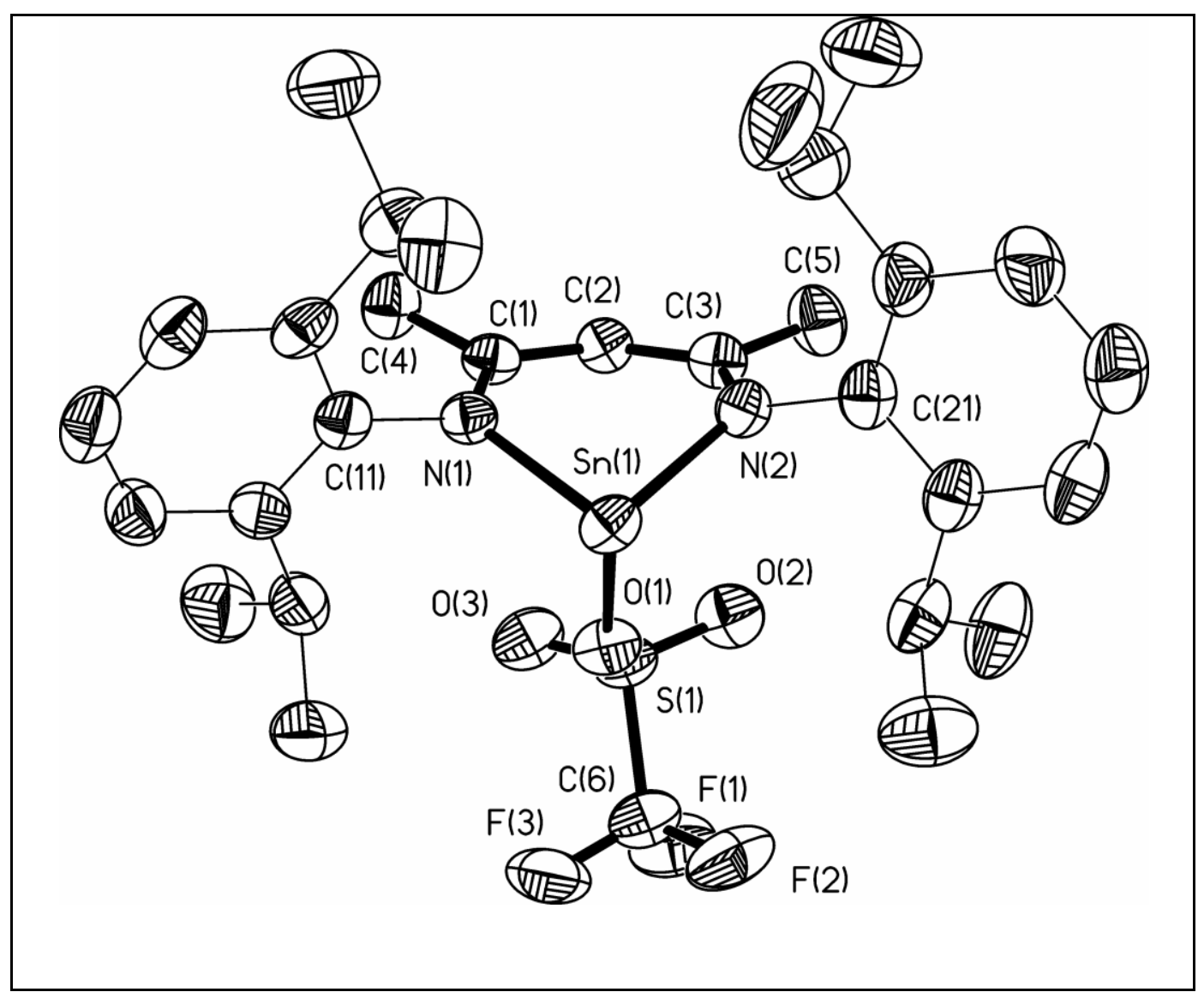

Figure 16. Molecular structure of 28 in the crystal (50\% probability thermal ellipsoids, $\mathrm{H}$ atoms not shown for clarity). Selected bond lengths $(\AA)$ and angles (deg): Sn(1)-N(1) 2.142(3), Sn(1)-N(2) 2.139(3), Sn(1)-O(1) 2.254(2), C(1)-N(1) 1.334(4), $\mathrm{C}(3)-\mathrm{N}(2) \quad 1.335(4) ; \mathrm{O}(1)-\mathrm{Sn}(1)-\mathrm{N}(1) \quad 87.39(10), \quad \mathrm{O}(1)-\mathrm{Sn}(1)-\mathrm{N}(2)$ 90.62(10), $\mathrm{N}(1)-\mathrm{Sn}(1)-\mathrm{N}(2) 87.78(10)$. 


\section{Summary and Outlook}

\subsection{Summary}

In this thesis, diketiminato ligands have been employed as a supporting moiety for germanium and tin compounds. The experimental results demonstrate that steric bulk and additional intramolecular coordination of the ligand can stabilize some unusual and unique compounds. In addition, these compounds may be useful as starting materials for further reactions.

The precursors, the Ge (II) chloride $\left[\left\{\mathrm{HC}(\mathrm{CMeNAr})_{2}\right\} \mathrm{GeCl}\right]$, (3) and $\mathrm{Sn}$ (II) chloride $\left[\left\{\mathrm{HC}(\mathrm{CMeNAr})_{2}\right\} \mathrm{SnCl}\right],(5)$ were synthesized in high yields and structurally characterized. The single crystal X-ray structures of $\mathbf{3}$ and $\mathbf{5}$ shows that both compounds are monomeric. The ligand is chelated to the metals and the metal centers adopt three coordinated sites and reside in distorted tetrahedral environments with one vertex occupied by a lone pair of electrons. This is the basic structural feature of these compounds.

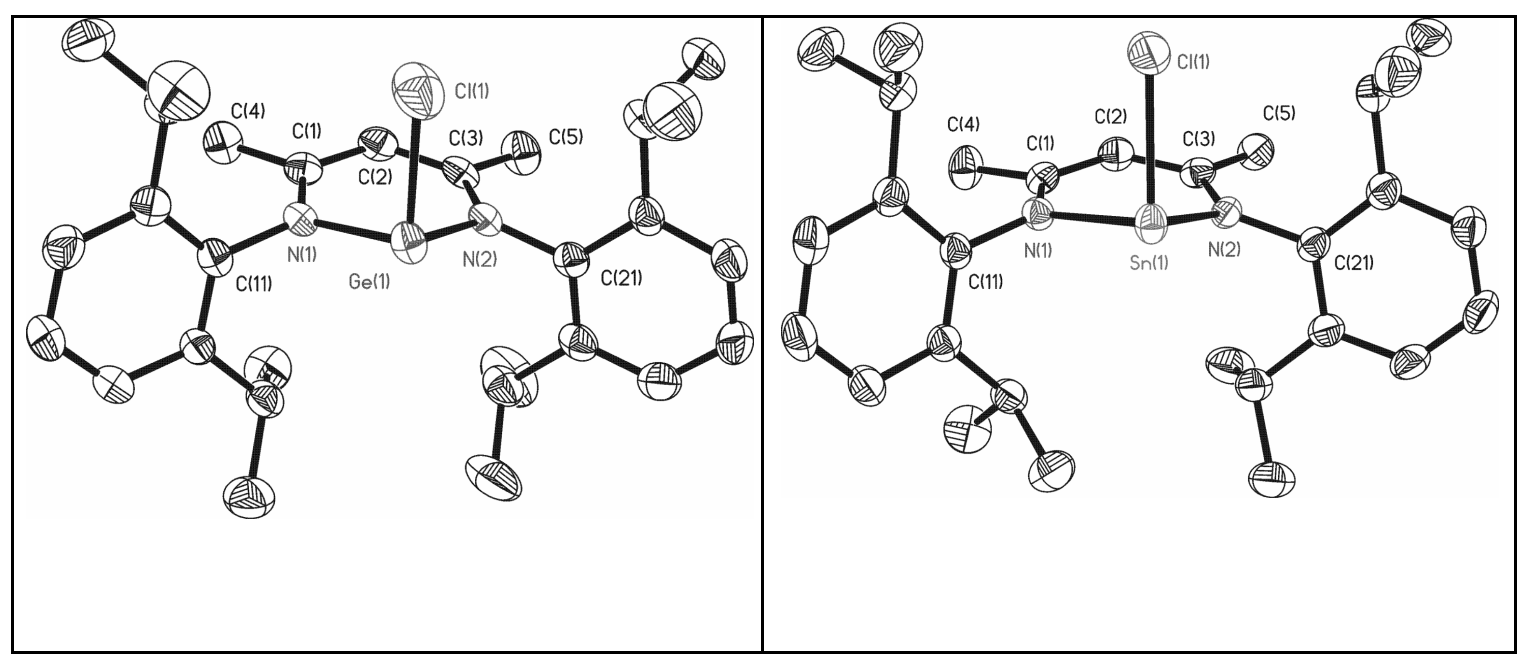

Structures of $\mathbf{3}$ and $\mathbf{5}$

$\left[\left\{\mathrm{HC}(\mathrm{CMeNAr})_{2}\right\} \mathrm{GeF}\right](\mathbf{8})$, the first structural characterized divalent organo germanium fluoride, was synthesized from the reaction of compound 3 with $\mathrm{Me}_{3} \mathrm{SnF}$. The reactivity of the electron lone pair on the germanium atom of $\mathbf{8}$ was examined with $\mathrm{Me}_{3} \mathrm{SiN}_{3}$. 


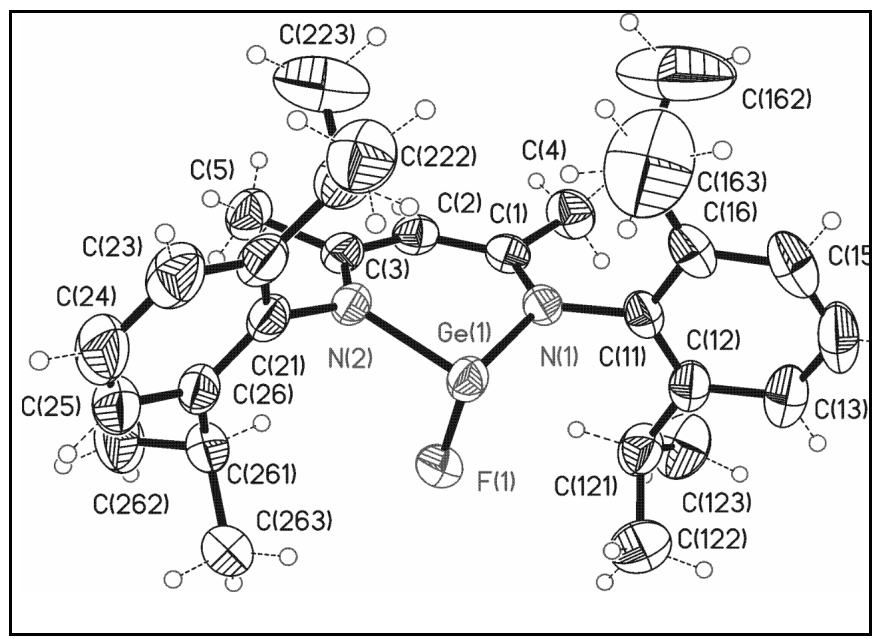

Structure of $\mathbf{8}$

Treatment of 3 with $\mathrm{NaBH}_{4}$ in THF under reflux led to the formation of $\left[\left\{\mathrm{HC}(\mathrm{CMeNAr})_{2}\right\} \mathrm{Ge}(\mathrm{H}) \mathrm{BH}_{3}\right] \mathbf{( 1 1 )}$; for the first time a $\mathrm{Ge}(\mathrm{II})$ hydride was prepared successfully. The coordinated $\mathrm{BH}_{3}$ in $\mathbf{1 1}$ can be easily removed with $\mathrm{PMe}_{3}$ yielding the free hydride $\left[\left\{\mathrm{HC}(\mathrm{CMeNAr})_{2}\right\} \mathrm{GeH}\right]$ (13). Reaction of $\mathbf{1 1}$ with $t \mathrm{BuLi}$ in diethyl ether led to $\left[\left\{\mathrm{HC}\left(\mathrm{C}\left(\mathrm{CH}_{2}\right) \mathrm{NAr}\right) \mathrm{CMeNAr}\right\} \mathrm{Ge}(\mathrm{H}) \mathrm{BH}_{3}\right] \mathrm{Li}\left(\mathrm{Et}_{2} \mathrm{O}\right)_{3}\left(\mathrm{Ar}=2,6-i \mathrm{Pr}_{2} \mathrm{C}_{6} \mathrm{H}_{3}\right) \quad(\mathbf{1 4})$, in which a hydrogen of one of the Me groups was eliminated, and this consequently resulted in the formation of a methylene group. Distinct difference in the NMR and IR spectra of compounds 11, 13 and 14 from those of the Ge(IV) congeners were found. The structures of $\mathbf{1 1}$ and $\mathbf{1 4}$ are shown below .

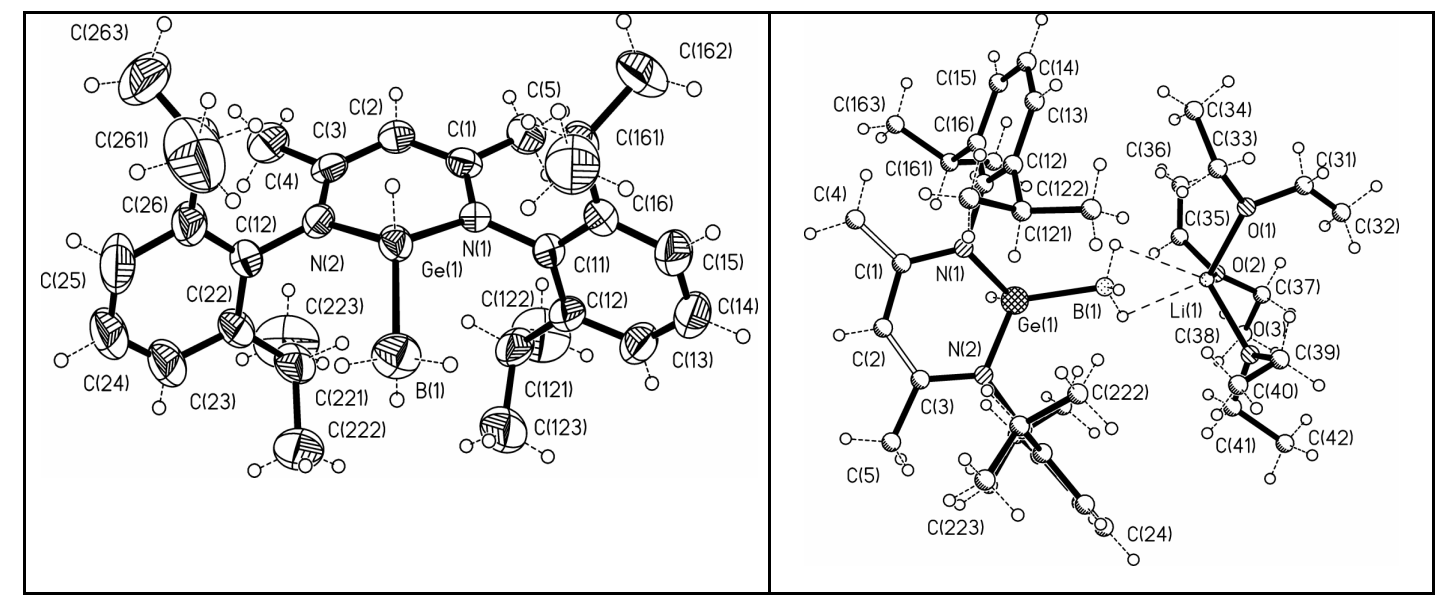

Structures of $\mathbf{1 1}$ and $\mathbf{1 4}$ 
Oxidative addition of elemental sulfur to compound $\mathbf{3}$ gave the example with a formal double bond between group 14 and 16 bearing a halide, [\{ $\left.\left.\mathrm{HC}(\mathrm{CMeNAr})_{2}\right\} \mathrm{Ge}(\mathrm{S}) \mathrm{Cl}\right](\mathrm{Ar}=$ 2,6-i $\operatorname{Pr}_{2} \mathrm{C}_{6} \mathrm{H}_{3}$ (15)). The fluoro analogue $\left[\left\{\mathrm{HC}(\mathrm{CMeNAr})_{2}\right\} \mathrm{Ge}(\mathrm{S}) \mathrm{F}\right]$ (16) has been generated by two routes: from 15 by fluorination with $\mathrm{Me}_{3} \mathrm{SnF}$ or from 8 by oxidative addition with elemental sulfur. The reactivity of $\mathbf{1 5}$ was preliminarily investigated using the smallest alkylation reagent MeLi to yield [ $\left.\left\{\mathrm{HC}(\mathrm{CMeNAr})_{2}\right\} \mathrm{Ge}(\mathrm{S}) \mathrm{Me}\right]\left(\mathrm{Ar}=2,6-i \mathrm{Pr}_{2} \mathrm{C}_{6} \mathrm{H}_{3}(\mathbf{1 7})\right)$. The so far known structurally characterized double bonded heavier main group elements are bound to bulky ligands. With this reaction a small alkyl group was introduced into such a system for the first time.

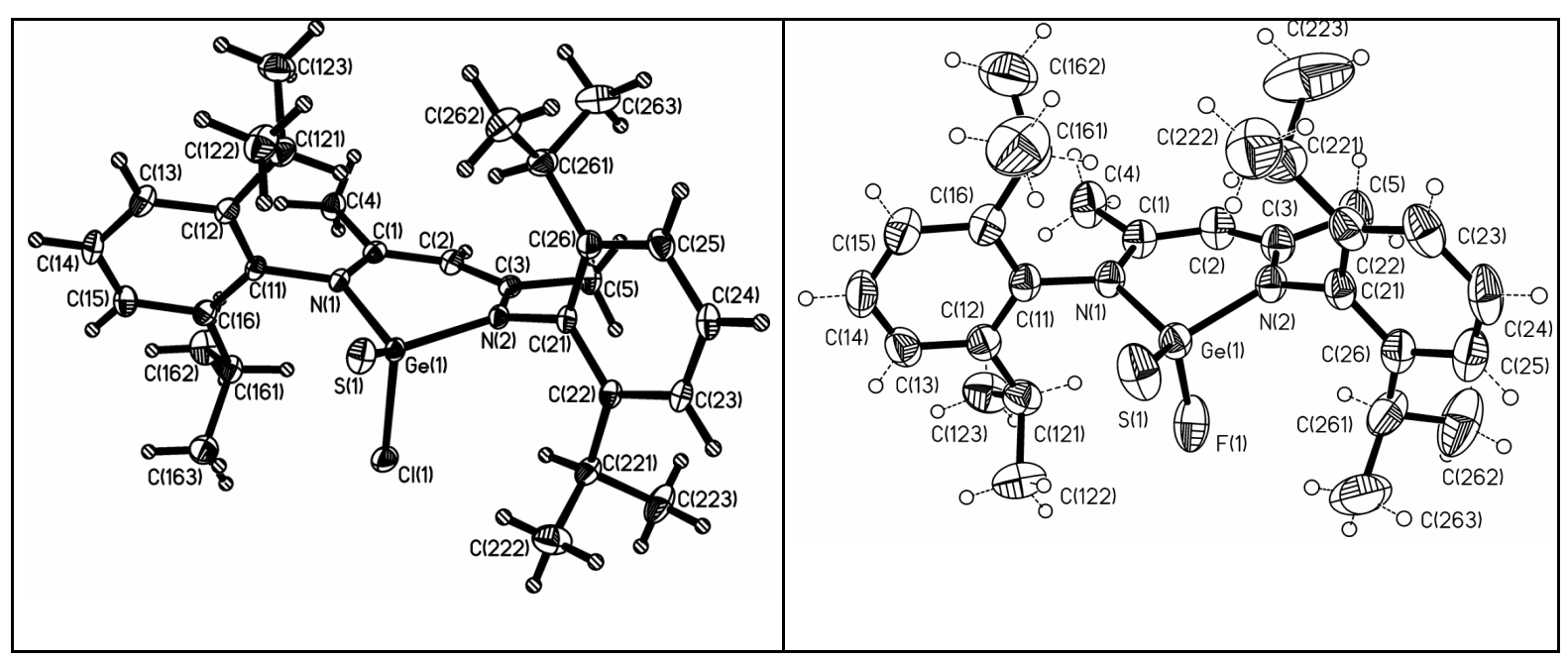

Structures of $\mathbf{1 5}$ and $\mathbf{1 6}$

The chemistry of heavier organoelement main group compounds bearing a halide and a double bond was also successfully extended to the selenium analogues of $15-17$. The compounds $\left[\left\{\mathrm{HC}(\mathrm{CMeNAr})_{2}\right\} \mathrm{Ge}(\mathrm{Se}) \mathrm{X}\right]\left(\mathrm{Ar}=2,6-i \mathrm{Pr}_{2} \mathrm{C}_{6} \mathrm{H}_{3}, \mathrm{X}=\mathrm{Cl}(\mathbf{1 8}), \mathrm{F}(\mathbf{1 9}), n \mathrm{Bu}\right.$ (20)) were obtained and $\mathbf{1 8}$ and $\mathbf{2 0}$ were structurally characterized. 


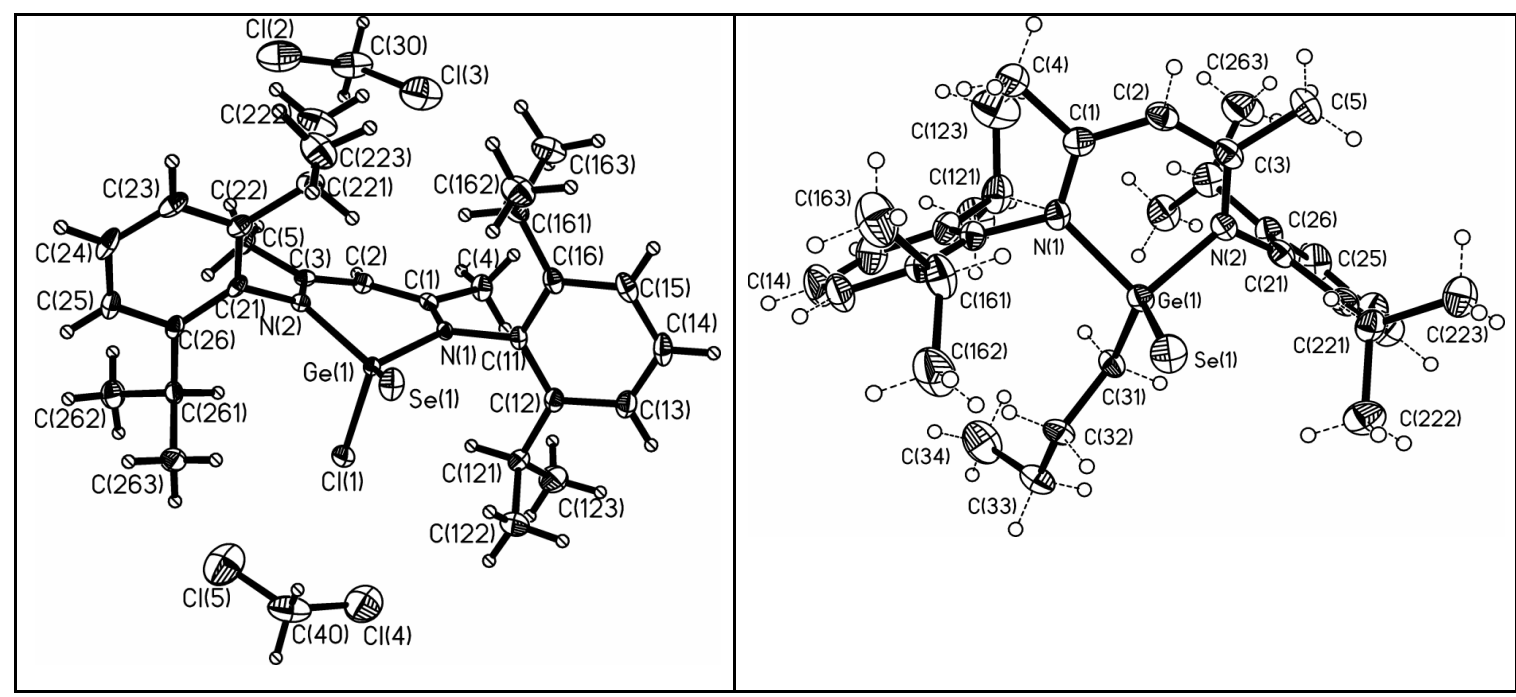

Structures of $\mathbf{1 8}$ and $\mathbf{2 0}$

The small alkyl substituted Ge(II) compounds stabilized by a diketiminato ligand, $\left[\left\{\mathrm{HC}(\mathrm{CMeNAr})_{2}\right\} \mathrm{GeR}\right]\left(\mathrm{Ar}=2,6-i \mathrm{Pr}_{2} \mathrm{C}_{6} \mathrm{H}_{3}, \mathrm{R}=\mathrm{Me}(\mathbf{2 1}), n \mathrm{Bu}(\mathbf{2 2})\right)$, were prepared and their structures determined by single crystal X-ray diffraction analyses. Compounds $\left[\left\{\mathrm{HC}(\mathrm{CMeNAr})_{2}\right\} \mathrm{Ge}(\mathrm{Se}) \mathrm{Me}\right] \quad(\mathbf{2 3}), \quad\left[\left\{\mathrm{HC}\left(\mathrm{C}\left(\mathrm{CH}_{2}\right) \mathrm{NAr}\right) \mathrm{CMeNAr}\right\} \mathrm{Ge}(\mathrm{Me}) \mathrm{N}(\mathrm{H}) \mathrm{SiMe}_{3}\right]$ (24), and $\left[\left\{\mathrm{HC}(\mathrm{CMeNAr})_{2}\right\} \mathrm{Ge}\left(\mathrm{Me}_{2}\right) \mathrm{I}\right]$ (25) were synthesized from 21 and appropriate reaction partners.

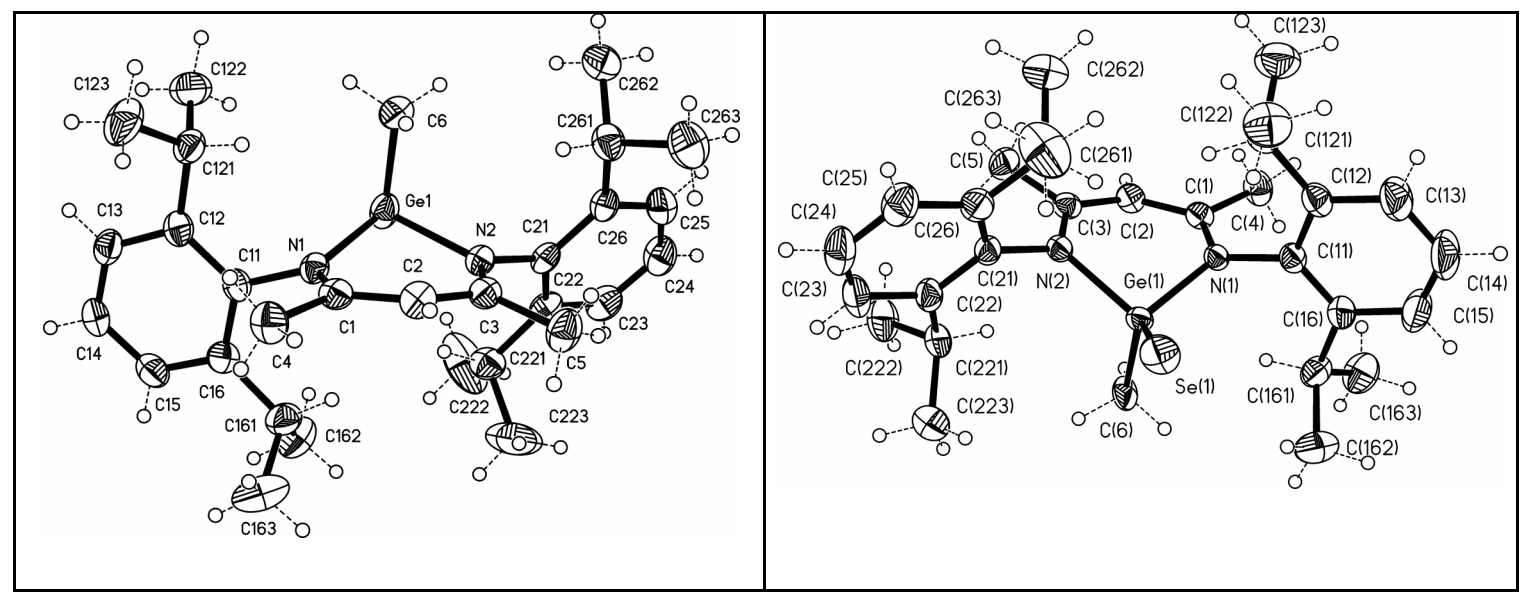

Structures of 21 and 23

Selected substrates were reacted with the compound $\left[\left\{\mathrm{HC}(\mathrm{CMeNAr})_{2}\right\} \mathrm{SnCl}\right](\mathbf{5})$ to synthesize $\mathrm{Sn}($ II) diketiminato complexes with ligands other than chlorine. The resulting 
derivatives $\quad\left[\left\{\mathrm{HC}(\mathrm{CMeNAr})_{2}\right\}_{2} \mathrm{Sn}\right] \quad(\mathbf{2 6}), \quad\left[\left\{\mathrm{HC}(\mathrm{CMeNAr})_{2}\right\} \mathrm{Sn} t \mathrm{Bu}\right] \quad$ (27), $\left[\left\{\mathrm{HC}(\mathrm{CMeNAr})_{2}\right\} \mathrm{SnOSO}_{2} \mathrm{CF}_{3}\right]$ (28), and $\left[\left\{\mathrm{HC}(\mathrm{CMeNAr})_{2}\right\} \mathrm{SnN}_{3}\right]$ (29) were fully characterized. The solid state structures of $\mathbf{2 6}$ and $\mathbf{2 8}$ were determined, and the structure of 27 was derived from its ${ }^{119} \mathrm{Sn}$ NMR.

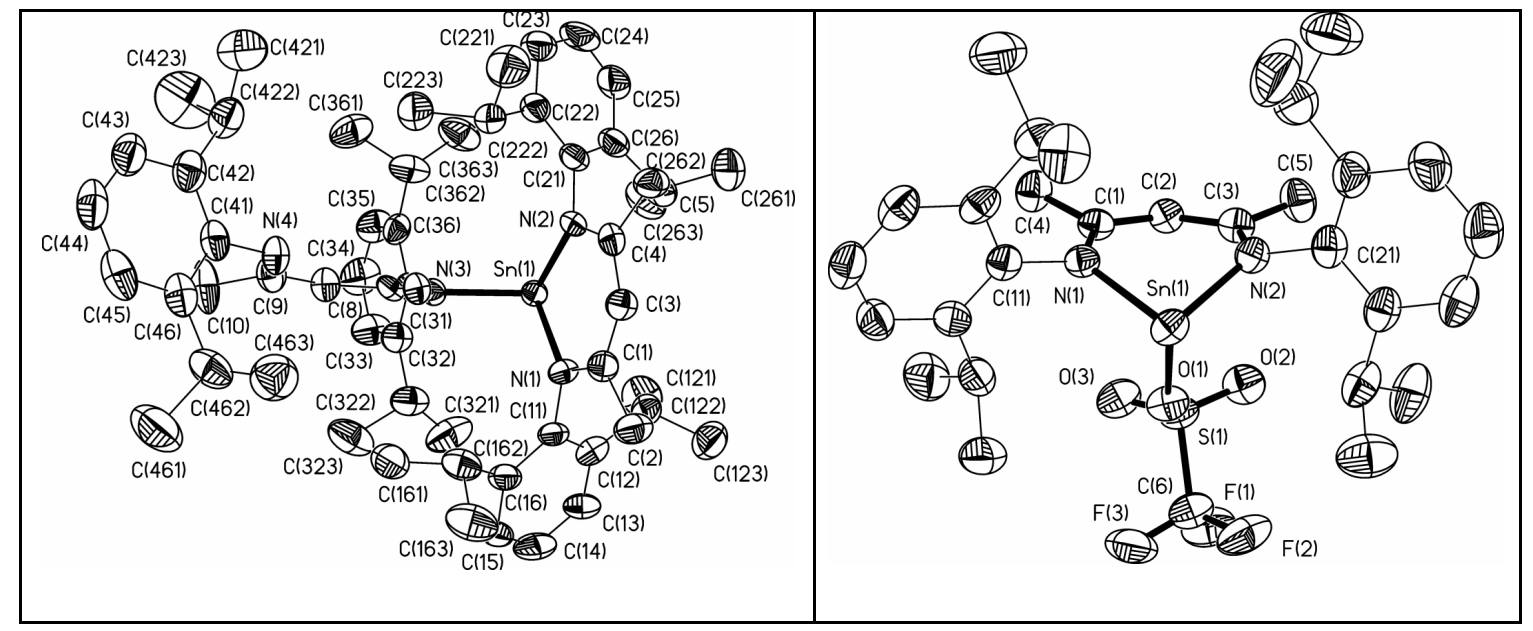

Structures of $\mathbf{2 6}$ and $\mathbf{2 8}$ 


\subsection{Outlook}

The focus of the work reported here has been on the syntheses, structures, and reactivity of divalent germanium and tin compounds containing bulky diketiminato ligands. Some important compounds, for instance, Ge (II) hydrides, fluorides, and the compounds involving multiple bonded heavier main group elements bearing a halide, were synthesized and structurally characterized for the first time. The reactivities of such compounds were checked preliminarily.

A continuation of this work would be:

- Exploring the property of the Ge(II)-H bond and the utilization of the lone pair of electron on the center metal for preparation of novel compounds .

- Synthesizing compounds involving a $\mathrm{Ge}=\mathrm{O}$ bond.

- Further studies of the properties of the compounds involving the moiety of $\mathrm{Ge}(\mathrm{E}) \mathrm{X}$ $(\mathrm{E}=\mathrm{O}, \mathrm{S}, \mathrm{Se}, \mathrm{Te} ; \mathrm{X}=\mathrm{F}, \mathrm{Cl})$. 


\section{Experimental Section}

\subsection{General procedures}

All experimental manipulations, unless otherwise stated, were carried out in an oxygen-free dry dinitrogen atmosphere using Schlenk glassware and techniques. ${ }^{49}$ The handling of solid samples and the preparation of samples for spectral measurements were carried out inside a MBraun MB150-GI glove-box where the $\mathrm{O}_{2}$ and $\mathrm{H}_{2} \mathrm{O}$ levels were normally kept below 2 ppm. The glassware used in all the manipulations was oven-dried at $150{ }^{\circ} \mathrm{C}$ for a minimum of $2 \mathrm{~h}$ before use, cooled to ambient temperature in vacuo, and flushed with nitrogen.

Melting points were determined in sealed capillaries on a Bühler SPA-1 apparatus.

Elemental analyses were carried out by the Analytical Laboratory of the Institute of Inorganic Chemistry at the University of Göttingen.

${ }^{1} \mathrm{H},{ }^{19} \mathrm{~F},{ }^{11} \mathrm{~B},{ }^{77} \mathrm{Se},{ }^{31} \mathrm{P},{ }^{119} \mathrm{Sn}$, and ${ }^{29} \mathrm{Si}$ NMR spectra $\left(\mathrm{CDCl}_{3}, \mathrm{C}_{6} \mathrm{D}_{6}\right.$, or toluene- $\mathrm{d}_{8}$ solutions) were recorded on Bruker AS-250 and Bruker AM-200 Advance spectrometers. Heteronuclear NMR spectra were recorded ${ }^{1} \mathrm{H}$ decoupled. Chemical shifts are reported in ppm with reference to external TMS, $\mathrm{CFCl}_{3}, \mathrm{BF}_{3}, \mathrm{Me}_{2} \mathrm{Se}, \mathrm{Me}_{4} \mathrm{Sn}$ positive values being downfield, and coupling constants $J$ in Hz. All NMR grade solvents were dried prior to use and the samples for measurements were freshly prepared in the glove-box.

EI-mass spectra were obtained on Finnigan MAT 8230 and Varian MAT CH5 spectrometers. Only the highest peak of the respective isotopic distribution is given.

IR spectra were recorded on a Bio-Rad Digilab FTS-7 spectrometer as Nujol mulls on $\mathrm{KBr}$ plates. Intensities were abbreviated as follows: s (strong), m (medium), w (weak). Only characteristic absorptions are listed.

$X$-ray structure determinations: crystals were mounted on glass fibers in a rapidly cooled perfluoropolyether. Diffraction data of all the crystals were collected on a Siemens/Stoe AED2 four circle diffractometer using Mo- $K_{\alpha}$ radiation $(\lambda=0.71073 \AA)$. The structures were solved by direct methods using the program SHELXS-97 $7^{50}$ and refined using $F^{2}$ on all data by full-matrix-least-squares with SHELXL-90. ${ }^{51}$ All non-hydrogen atoms were refined anisotropically. All hydrogen atoms were included in the model at geometrically calculated 
positions and refined using a riding model. Crystal data for all the compounds related to the data collection, structure solution, and refinement are listed in Section 6. in tabular form.

\subsection{Starting materials}

The starting materials, $\left[\mathrm{HC}(\mathrm{CMeNAr})_{2}\right] \mathrm{H},{ }^{52} \mathrm{GeCl} \cdot$ dioxane, ${ }^{53}$ and $\mathrm{Me}_{3} \mathrm{SnF}^{54}$ were prepared by literature methods. Other chemicals used in this work were purchased from Aldrich Chemical Co, ACROS, and Fluka Co and used without further purification.

\subsection{Synthesis}

\subsubsection{Synthesis of $\left[\mathrm{HC}(\mathrm{CMeNAr})_{2}\right] \mathrm{Li}\left(\mathrm{OEt}_{2}\right)\left(\mathrm{Ar}=2,6-i \operatorname{Pr}_{2} \mathrm{C}_{6} \mathrm{H}_{3}\right)(1)$}

A solution of MeLi (13.0 mL, $1.6 \mathrm{M}$ in diethyl ether, $20.0 \mathrm{mmol}$ ) was added dropwise to a stirred solution of $\left[\mathrm{HC}(\mathrm{CMeNAr})_{2}\right] \mathrm{H}(8.36 \mathrm{~g}, 20.0 \mathrm{mmol})$ in $n$ hexane $(40 \mathrm{~mL})$ at $-78{ }^{\circ} \mathrm{C}$. The reaction mixture was allowed to warm to room temperature and was stirred for $3 \mathrm{~h}$. After filtration, storage of the filtrate in a $-32{ }^{\circ} \mathrm{C}$ freezer for $2 \mathrm{~d}$ afforded colorless crystals of $\mathbf{1}$.

1: Yield: $8.9 \mathrm{~g}(90 \%) .{ }^{1} \mathrm{H}$ NMR $\left(\mathrm{C}_{6} \mathrm{D}_{6}\right): \delta 0.49\left(\mathrm{t}, 6 \mathrm{H}, \mathrm{O}\left(\mathrm{CH}_{2} \mathrm{CH}_{3}\right)_{2}, J=7.0 \mathrm{~Hz}\right), 1.16(\mathrm{~d}$, $\left.12 \mathrm{H}, \mathrm{CH}\left(\mathrm{CH}_{3}\right)_{2}, J=6.9 \mathrm{~Hz}\right), 1.22\left(\mathrm{~d}, 12 \mathrm{H}, \mathrm{CH}\left(\mathrm{CH}_{3}\right)_{2}, J=6.9 \mathrm{~Hz}\right), 1.88(\mathrm{~s}, 6 \mathrm{H}, \mathrm{Me})$, 2.76 (q, $\left.4 \mathrm{H}, \mathrm{O}\left(\mathrm{CH}_{2} \mathrm{CH}_{3}\right)_{2}, J=7.0 \mathrm{~Hz}\right), 3.22-3.45\left(\mathrm{~m}, 4 \mathrm{H}, \mathrm{CH}\left(\mathrm{CH}_{3}\right)_{2}\right), 4.98(\mathrm{~s}, 1 \mathrm{H}, \gamma-$ $\mathrm{CH}), 7.00-7.10\left(\mathrm{~m}, 6 \mathrm{H}, 2,6-i \mathrm{Pr}_{2} \mathrm{C}_{6} H_{3}\right) \mathrm{ppm}$.

\subsubsection{Synthesis of $\left[\mathrm{HC}(\mathrm{CMeNAr})_{2}\right] \mathrm{Li}\left(\mathrm{OEt}_{2}\right)\left(\mathrm{Ar}=2,6-\mathrm{Me}_{2} \mathrm{C}_{6} \mathrm{H}_{3}\right)(2)$}

The procedure was the same as for 1.

2: Yield: $7.5 \mathrm{~g}(85 \%) .{ }^{1} \mathrm{H}$ NMR $\left(\mathrm{C}_{6} \mathrm{D}_{6}\right): \delta 0.45\left(\mathrm{t}, 6 \mathrm{H}, \mathrm{O}\left(\mathrm{CH}_{2} \mathrm{CH}_{3}\right)_{2}, J=7.0 \mathrm{~Hz}\right), 1.95$ (s, $6 \mathrm{H}, \beta-M e), 2.55\left(\mathrm{~s}, 12 \mathrm{H}, \mathrm{Ar}-\mathrm{CH}_{3}\right), 2.79\left(\mathrm{q}, 4 \mathrm{H}, \mathrm{O}\left(\mathrm{CH}_{2} \mathrm{CH}_{3}\right)_{2}, J=7.0 \mathrm{~Hz}\right), 5.71(\mathrm{~s}, 1$ $\mathrm{H}, \gamma-\mathrm{CH}), 7.15-7.25\left(\mathrm{~m}, 6 \mathrm{H}, 2,6-\mathrm{Me}_{2} \mathrm{C}_{6} \mathrm{H}_{3}\right) \mathrm{ppm}$. 


\subsubsection{Synthesis $\left[\left\{\mathrm{HC}(\mathrm{CMeNAr})_{2}\right\} \mathrm{GeCl}\right]\left(\mathrm{Ar}=2,6-i \mathrm{Pr}_{2} \mathrm{C}_{6} \mathrm{H}_{3}\right)(3)$}

A solution of $1(0.50 \mathrm{~g}, 1.0 \mathrm{mmol})$ in diethyl ether $(20 \mathrm{~mL})$ was added dropwise to a stirred suspension of $\mathrm{GeCl}_{2}$-dioxane $(0.27 \mathrm{~g}, 1.0 \mathrm{mmol})$ in diethyl ether $(10 \mathrm{~mL})$ at $-78{ }^{\circ} \mathrm{C}$. The reaction mixture was allowed to warm to room temperature and was stirred for another 6 h. After removal of all volatiles, the residue was extracted with $n$ hexane $(20 \mathrm{~mL})$. Storage of the extract in a $-32{ }^{\circ} \mathrm{C}$ freezer for $3 \mathrm{~d}$ afforded colorless crystals of 3 .

3: Yield: $0.33 \mathrm{~g}(63 \%)$. Mp: 197 - $199{ }^{\circ} \mathrm{C}$. Anal.: calcd for $\mathrm{C}_{29} \mathrm{H}_{41} \mathrm{ClGeN}_{2}$ (525.68): $\mathrm{C}$, 66.21; H, 7.79; Cl, 6.75; N, 5.32, found: C, 66.01; H, 8.0; Cl, 4.00; N, 5.2. EI-MS : m/e (\%) $526\left(\mathrm{M}^{+}, 65\right), 491\left([\mathrm{M}-\mathrm{Cl}]^{+}, 100\right) .{ }^{1} \mathrm{H} \mathrm{NMR}\left(\mathrm{C}_{6} \mathrm{D}_{6}\right): \delta 1.01\left(\mathrm{~d}, 6 \mathrm{H}, \mathrm{CH}\left(\mathrm{CH}_{3}\right)_{2}, J=\right.$ $6.9 \mathrm{~Hz}), 1.19\left(\mathrm{~d}, 6 \mathrm{H}, \mathrm{CH}\left(\mathrm{CH}_{3}\right)_{2}, J=6.9 \mathrm{~Hz}\right), 1.20\left(\mathrm{~d}, 6 \mathrm{H}, \mathrm{CH}\left(\mathrm{CH}_{3}\right)_{2}, J=6.9 \mathrm{~Hz}\right), 1.46$ $\left(\mathrm{d}, 6 \mathrm{H}, \mathrm{CH}\left(\mathrm{CH}_{3}\right)_{2}, J=6.9 \mathrm{~Hz}\right), 1.60\left(\mathrm{~s}, 6 \mathrm{H}, \beta-\mathrm{CH}_{3}\right), 3.05-3.20\left(\mathrm{~m}, 2 \mathrm{H}, \mathrm{CH}\left(\mathrm{CH}_{3}\right)_{2}\right)$, $3.80-4.00\left(\mathrm{~m}, 2 \mathrm{H}, \mathrm{CH}\left(\mathrm{CH}_{3}\right)_{2}\right), 5.14(\mathrm{~s}, 1 \mathrm{H}, \gamma-\mathrm{CH}), 7.00-7.10\left(\mathrm{~m}, 6 \mathrm{H}, 2,6-i \mathrm{Pr}_{2} \mathrm{C}_{6} \mathrm{H}_{3}\right)$ ppm.

\subsubsection{Synthesis of $\left[\left\{\mathrm{HC}(\mathrm{CMeNAr})_{2}\right\} \mathrm{GeCl}\right]\left(\mathrm{Ar}=2,6-\mathrm{Me}_{2} \mathrm{C}_{6} \mathrm{H}_{3}\right)(4)$}

A solution of $\left[\mathrm{HC}(\mathrm{CMeNAr})_{2} \mathrm{Li}\left(\mathrm{OEt}_{2}\right)\right](0.41 \mathrm{~g}, 1.0 \mathrm{mmol})$ in diethyl ether $(20 \mathrm{~mL})$ was reacted at $-78{ }^{\circ} \mathrm{C}$ with $\mathrm{GeCh}_{2}$ dioxane $(0.27 \mathrm{~g}, 1.0 \mathrm{mmol})$ to yield 4 . Pure 4 was obtained after extraction with hot $\left(70{ }^{\circ} \mathrm{C}\right)$ toluene $(15 \mathrm{~mL})$.

4: Yield: $0.25 \mathrm{~g}(60 \%)$. Mp: $221-224{ }^{\circ} \mathrm{C}$. Anal.: calcd for $\mathrm{C}_{21} \mathrm{H}_{25} \mathrm{ClGeN}_{2}$ : C, 61.00; $\mathrm{H}$, 6.09; $\mathrm{Cl}, 8.57 ; \mathrm{N}, 6.77$, found $\mathrm{C}, 61.1 ; \mathrm{H}, 6.0 ; \mathrm{Cl}, 8.6 ; \mathrm{N}, 6.7$. EI-MS: $m / e 414\left(\mathrm{M}^{+}\right), 379$ $\left([\mathrm{M}-\mathrm{Cl}]^{+}\right) .{ }^{1} \mathrm{H} \mathrm{NMR}\left(\mathrm{CDCl}_{3}\right): \delta 1.85\left(\mathrm{~s}, 6 \mathrm{H}, \beta-\mathrm{CH}_{3}\right), 2.17\left(\mathrm{~s}, 6 \mathrm{H}, \mathrm{Ar}-\mathrm{CH}_{3}\right), 2.49$ (s, 6 $\left.\mathrm{H}, \mathrm{Ar}-\mathrm{CH}_{3}\right), 5.50$ (s, $1 \mathrm{H}, \gamma-\mathrm{CH}$ ), $7.08-7.29$ (m, $\left.6 \mathrm{H}, \mathrm{Ar}-H\right) \mathrm{ppm}$.

\subsubsection{Synthesis of $\left[\left\{\mathrm{HC}(\mathrm{CMeNAr})_{2}\right\} \mathrm{SnCl}\right]\left(\mathrm{Ar}=2,6-i \mathrm{Pr}_{2} \mathrm{C}_{6} \mathrm{H}_{3}\right)(5)$}


A solution of $1(0.50 \mathrm{~g}, 1.0 \mathrm{mmol})$ in diethyl ether $(15 \mathrm{~mL})$ was added dropwise to a stirred suspension of $\mathrm{SnCl}_{2}(0.19 \mathrm{~g}, 1.0 \mathrm{mmol})$ in diethyl ether $(10 \mathrm{~mL})$ at $-50{ }^{\circ} \mathrm{C}$. The reaction mixture was allowed to warm to room temperature and stirred for another $12 \mathrm{~h}$. The precipitate was filtered and the solvent was concentrated $c a .10 \mathrm{~mL}$. Storage of the remaining solution in a $-32{ }^{\circ} \mathrm{C}$ freezer for $2 \mathrm{~d}$ afforded yellow crystals of $\mathbf{5}$. Recrystallization from nhexane $(15 \mathrm{~mL})$ in a $-10{ }^{\circ} \mathrm{C}$ freezer for $2 \mathrm{~d}$ afforded crystals suitable for X-ray diffraction analysis.

5: Yield: 0.42 g (73\%). Mp: $207-211^{\circ} \mathrm{C}$. Anal.: calcd for $\mathrm{C}_{29} \mathrm{H}_{41} \mathrm{Cl} \mathrm{N} \mathrm{N}_{2} \mathrm{Sn}$ (571.78): $\mathrm{C}$, 60.91; H, 7.23; Cl, 6.20; N, 4.90. found: C, 60.3; H, 7.1; Cl, 6.3; N, 5.0. EI-MS: $m / z 572$ $\left(\mathrm{M}^{+}\right) .{ }^{1} \mathrm{H} \mathrm{NMR}\left(\mathrm{C}_{6} \mathrm{D}_{6}\right): \delta 1.03\left(\mathrm{~d}, 6 \mathrm{H}, \mathrm{CH}\left(\mathrm{CH}_{3}\right)_{2}, J=6.9 \mathrm{~Hz}\right), 1.16\left(\mathrm{~d}, 6 \mathrm{H}, \mathrm{CH}\left(\mathrm{CH}_{3}\right)_{2}\right.$, $J=6.9 \mathrm{~Hz}), 1.19\left(\mathrm{~d}, 6 \mathrm{H}, \mathrm{CH}\left(\mathrm{CH}_{3}\right)_{2}, J=6.9 \mathrm{~Hz}\right), 1.42\left(\mathrm{~d}, 6 \mathrm{H}, \mathrm{CH}\left(\mathrm{CH}_{3}\right)_{2}, J=6.9 \mathrm{~Hz}\right)$, $1.61\left(\mathrm{~s}, 6 \mathrm{H}, \beta-\mathrm{CH}_{3}\right), 3.00-3.20\left(\mathrm{~m}, 2 \mathrm{H}, \mathrm{CH}\left(\mathrm{CH}_{3}\right)_{2}\right), 3.85-3.98\left(\mathrm{~m}, 2 \mathrm{H}, \mathrm{CH}\left(\mathrm{CH}_{3}\right)_{2}\right)$, $5.05(\mathrm{~s}, 1 \mathrm{H}, \gamma-\mathrm{CH}), 7.06\left(\mathrm{~m}, 6 \mathrm{H}, 2,6-i \mathrm{Pr}_{2} \mathrm{C}_{6} H_{3}\right) \mathrm{ppm} .{ }^{119} \mathrm{Sn} \mathrm{NMR}\left(\mathrm{C}_{6} \mathrm{D}_{6}\right): \delta-224 \mathrm{ppm}$.

\subsubsection{Synthesis of $\left[\left\{\mathrm{HC}(\mathrm{CMeNAr})_{2}\right\} \mathrm{GeF}\right]\left(\mathrm{Ar}=2,6-i \mathrm{Pr}_{2} \mathrm{C}_{6} \mathrm{H}_{3}\right)(8)$}

A solution of $3(0.53 \mathrm{~g}, 1.0 \mathrm{mmol})$ in dichloromethane $(20 \mathrm{~mL})$ was added to a stirred suspension of $\mathrm{Me}_{3} \mathrm{SnF}(0.20 \mathrm{~g}, 1.1 \mathrm{mmol})$ in dchloromethane $(10 \mathrm{~mL})$ and the reaction mixture was stirred at room temperature for 2 days. After removal of all volatiles the residue was extracted with $n$ hexane $(20 \mathrm{~mL})$. Storage of the extract at $-32{ }^{\circ} \mathrm{C}$ for $24 \mathrm{~h}$ afforded colorless needle-shaped crystals of $\mathbf{8}$.

8: Yield: 0.45 g (88 \%). Mp: $182-184{ }^{\circ} \mathrm{C}$. Anal.: calcd for $\mathrm{C}_{29} \mathrm{H}_{41} \mathrm{FGeN}_{2}$ (510.25): C, 66.21; H, 7.79; N, 5.32; found: C, 66.0; H, 7.80; N, 5.2. EI-MS: m/e $510\left(\mathrm{M}^{+}\right), 475([\mathrm{M}-$ $\left.\left.\mathrm{CH}_{3}-\mathrm{F}\right]{ }^{+}\right) . \quad{ }^{1} \mathrm{H}$ NMR $\left(\mathrm{C}_{6} \mathrm{D}_{6}\right): \delta 1.07\left(\mathrm{~d}, 6 \mathrm{H}, \mathrm{CH}\left(\mathrm{CH}_{3}\right)_{2}, J=6.9 \mathrm{~Hz}\right), 1.17(\mathrm{~d}, 6 \mathrm{H}$, $\left.\mathrm{CH}\left(\mathrm{CH}_{3}\right)_{2}, J=6.9 \mathrm{~Hz}\right), 1.22\left(\mathrm{~d}, 6 \mathrm{H}, \mathrm{CH}\left(\mathrm{CH}_{3}\right)_{2}, J=6.9 \mathrm{~Hz}\right), 1.40\left(\mathrm{~d}, 6 \mathrm{H}, \mathrm{CH}\left(\mathrm{CH}_{3}\right)_{2}, J=\right.$ $6.9 \mathrm{~Hz}), 1.60\left(\mathrm{~s}, 6 \mathrm{H}, \beta-\mathrm{CH}_{3}\right), 3.05-3.20\left(\mathrm{~m}, 2 \mathrm{H}, \mathrm{CH}\left(\mathrm{CH}_{3}\right)_{2}\right), 3.70-3.82(\mathrm{~m}, 2 \mathrm{H}$, 
$\left.\mathrm{CH}\left(\mathrm{CH}_{3}\right)_{2}\right), 5.05(\mathrm{~s}, 1 \mathrm{H}, \gamma-\mathrm{CH}), 7.05-7.10\left(\mathrm{~m}, 6 \mathrm{H}, 2,6-i \mathrm{Pr}_{2} \mathrm{C}_{6} H_{3}\right)$ ppm. ${ }^{19} \mathrm{~F} \mathrm{NMR}$ $\left(\mathrm{C}_{6} \mathrm{D}_{6}\right): \delta 50.58 \mathrm{ppm}$. IR (Nujol): v $543 \mathrm{~cm}^{-1}(\mathrm{GeF})$. 


\subsubsection{Synthesis of $\left[\left\{\mathrm{HC}(\mathrm{CMeNAr})_{2}\right\} \mathrm{GeF}\right]\left(\mathrm{Ar}=2,6-\mathrm{Me}_{2} \mathrm{C}_{6} \mathrm{H}_{3}\right)(9)$}

The procedure is the same like that described for $\mathbf{8}$.

9:Yield: $0.31 \mathrm{~g}$ (80 \%). Mp: 186 - $189{ }^{\circ} \mathrm{C}$. Anal.: calcd for $\mathrm{C}_{21} \mathrm{H}_{25} \mathrm{FGeN}_{2}$ (389.10): C, 63.53; H, 6.35; N, 7.06; found: C, 63.6; H, 6.3; N, 7.2. EI-MS: m/e $398\left(\mathrm{M}^{+}\right), 379([\mathrm{M}-$ $\left.\mathrm{F}]^{+}\right) .{ }^{1} \mathrm{H} \mathrm{NMR}\left(\mathrm{CDCl}_{3}\right): \delta 1.83(\mathrm{~s}, 6 \mathrm{H}, \beta-M e), 2.13(\mathrm{~s}, 6 \mathrm{H}, \mathrm{Ar}-\mathrm{Me}), 2.41$ (s, $\left.6 \mathrm{H}, \mathrm{Ar}-\mathrm{Me}\right)$, $5.40(\mathrm{~s}, 1 \mathrm{H}, \gamma-\mathrm{CH}), 7.05-7.15(\mathrm{~m}, 6 \mathrm{H}, \mathrm{Ar}-H) \mathrm{ppm} .{ }^{19} \mathrm{~F} \mathrm{NMR}\left(\mathrm{CDCl}_{3}\right): \delta 54.46 \mathrm{ppm}$. IR (Nujol): v $539 \mathrm{~cm}^{-1}(\mathrm{GeF})$.

\subsubsection{Synthesis of $\left[\left\{\mathrm{HC}(\mathrm{CMeNAr})_{2}\right\} \mathrm{Ge}(\mathrm{F}) \mathrm{NSiMe}\right]\left(\mathrm{Ar}=2,6-i \operatorname{Pr}_{2} \mathrm{C}_{6} \mathrm{H}_{3}\right)(10)$}

A solution of $8(0.51 \mathrm{~g}, 1.0 \mathrm{mmol})$ and $\mathrm{Me}_{3} \mathrm{SiN}_{3}(0.12 \mathrm{~g}, 1.0 \mathrm{mmol})$ in toluene $(25 \mathrm{~mL})$ was refluxed for $3 \mathrm{~h}$. After removal of all volatiles and washing of the residue with $n$ hexane (2 $\times 5 \mathrm{~mL}) \mathbf{1 0}$ was obtained as a pale yellow powder. Storage of the slightly yellow solution of $\mathbf{1 0}$ in a $-32{ }^{\circ} \mathrm{C}$ freezer gave pale yellow crystals of $\mathbf{1 0}$.

10: Yield: $0.47 \mathrm{~g}(79 \%)$. Mp: $167-169{ }^{\circ} \mathrm{C}$. EI-MS: $m / e 597\left(\mathrm{M}^{+}\right), 578\left([\mathrm{M}-\mathrm{F}]^{+}\right) .{ }^{1} \mathrm{H}$ NMR $\left(\mathrm{C}_{6} \mathrm{D}_{6}\right): \delta 0.00\left(\mathrm{~s}, 9 \mathrm{H}, \mathrm{Si}\left(\mathrm{CH}_{3}\right)_{3}\right), 1.11\left(\mathrm{~d}, 6 \mathrm{H}, \mathrm{CH}\left(\mathrm{CH}_{3}\right)_{2}, J=6.9 \mathrm{~Hz}\right), 1.21(\mathrm{~d}, 6 \mathrm{H}$, $\left.\mathrm{CH}\left(\mathrm{CH}_{3}\right)_{2}, J=6.9 \mathrm{~Hz}\right), 1.23\left(\mathrm{~d}, 6 \mathrm{H}, \mathrm{CH}\left(\mathrm{CH}_{3}\right)_{2}, J=6.9 \mathrm{~Hz}\right), 1.51\left(\mathrm{~d}, 6 \mathrm{H}, \mathrm{CH}\left(\mathrm{CH}_{3}\right)_{2}, J=\right.$ $6.9 \mathrm{~Hz}), 1.54\left(\mathrm{~s}, 6 \mathrm{H}, \beta-\mathrm{CH}_{3}\right), 3.08-3.12\left(\mathrm{~m}, 2 \mathrm{H}, \mathrm{CH}\left(\mathrm{CH}_{3}\right)_{2}\right), 3.72-3.78(\mathrm{~m}, 2 \mathrm{H}$, $\left.\mathrm{C} H\left(\mathrm{CH}_{3}\right)_{2}\right), 4.98(\mathrm{~s}, 1 \mathrm{H}, \gamma-\mathrm{CH}), 7.04-7.08\left(\mathrm{~m}, 6 \mathrm{H}, 2,6-i \operatorname{Pr}_{2} \mathrm{C}_{6} H_{3}\right)$ ppm. ${ }^{19} \mathrm{~F} \mathrm{NMR}$ $\left(\mathrm{C}_{6} \mathrm{D}_{6}\right): \delta 71.05 \mathrm{ppm} .{ }^{29} \mathrm{Si} \mathrm{NMR}\left(\mathrm{C}_{6} \mathrm{D}_{6}\right): \delta 13.85 \mathrm{ppm}$.

\subsubsection{Synthesis of $\left[\left\{\mathrm{HC}(\mathrm{CMeNAr})_{2}\right\} \mathrm{GeH}\left(\mathrm{BH}_{3}\right)\right]\left(\mathrm{Ar}=2,6-i \mathrm{Pr}_{2} \mathrm{C}_{6} \mathrm{H}_{3}\right)(11)$}

A solution of $3(0.53 \mathrm{~g}, 1.0 \mathrm{mmol})$ in THF $(20 \mathrm{~mL})$ was added to a stirred suspension of $\mathrm{NaBH}_{4}$ (excess) in THF $(10 \mathrm{~mL})$ and the reaction mixture refluxed for $12 \mathrm{~h}$. After removal of 
all volatiles the residue was extracted with diethyl ether $(20 \mathrm{~mL})$. Storage of the slightly greenish extract in a $-32{ }^{\circ} \mathrm{C}$ freezer for $24 \mathrm{~h}$ afforded colorless crystals of $\mathbf{1 1}$.

11: Yield: 0.44 g (87 \%). Mp: 193 - $195{ }^{\circ} \mathrm{C}$. Anal.: calcd for $\mathrm{C}_{29} \mathrm{H}_{49} \mathrm{BGeN}_{2}$ (506.35).: C, 68.96; H, 8.98; N, 5.55; found: C, 68.9; H, 9.0; N, 5.7. EI-MS: $m / e 491\left(\left[\mathrm{M}-\mathrm{BH}_{3}-\right.\right.$ $\left.\mathrm{H}]^{+}\right) .{ }^{1} \mathrm{H}$ NMR $\left(\mathrm{C}_{6} \mathrm{D}_{6}\right): \delta 1.06\left(\mathrm{~d}, 6 \mathrm{H}, \mathrm{CH}\left(\mathrm{CH}_{3}\right)_{2}, J=6.9 \mathrm{~Hz}\right), 1.09\left(\mathrm{~d}, 6 \mathrm{H}, \mathrm{CH}\left(\mathrm{CH}_{3}\right)_{2}, J\right.$ $=6.9 \mathrm{~Hz}), 1.25\left(\mathrm{~d}, 6 \mathrm{H}, \mathrm{CH}\left(\mathrm{CH}_{3}\right)_{2}, J=6.9 \mathrm{~Hz}\right), 1.45\left(\mathrm{~s}, 6 \mathrm{H}, \beta-\mathrm{CH}_{3}\right), 1.47(\mathrm{~d}, 6 \mathrm{H}$, $\left.\mathrm{CH}\left(\mathrm{CH}_{3}\right)_{2}, J=6.9 \mathrm{~Hz}\right), 2.85-3.05\left(\mathrm{~m}, 2 \mathrm{H}, \mathrm{CH}\left(\mathrm{CH}_{3}\right)_{2}\right), 3.25-3.45\left(\mathrm{~m}, 2 \mathrm{H}, \mathrm{CH}\left(\mathrm{CH}_{3}\right)_{2}\right)$, $4.88(\mathrm{~s}, 1 \mathrm{H}, \gamma-\mathrm{CH}), 6.95-7.15\left(\mathrm{~m}, 6 \mathrm{H}, 2,6-i \operatorname{Pr}_{2} \mathrm{C}_{6} H_{3}\right) \mathrm{ppm} .{ }^{11} \mathrm{~B} \mathrm{NMR}\left(\mathrm{C}_{6} \mathrm{D}_{6}\right): \delta-41.94$ ppm. IR (Nujol): v 2370, 2333, $1927 \mathrm{~cm}^{-1}\left(\mathrm{BH}_{3}, \mathrm{GeH}\right)$.

\subsubsection{Synthesis of $\left[\left\{\mathrm{HC}(\mathrm{CMeNAr})_{2}\right\} \mathrm{Ge}(\mathrm{H}) \mathrm{BH}_{3}\right]\left(\mathrm{Ar}=2,6-\mathrm{Me}_{2} \mathrm{C}_{6} \mathrm{H}_{3}\right)(12)$}

The procedure is the same like that of $\mathbf{1 1}$.

12: Yield: $0.32 \mathrm{~g}(81 \%)$. Mp: $184-187{ }^{\circ} \mathrm{C}$. Anal.: calcd for $\mathrm{C}_{21} \mathrm{H}_{29} \mathrm{BGeN}_{2}$ (393.20): C, 64.20; H, 7.44; N, 7.13; found: C, 64.4; H, 7.5; N, 7.2. EI-MS: $m / e 379\left(\left[\mathrm{M}-\mathrm{BH}_{3}\right]^{+}\right) .{ }^{1} \mathrm{H}$ $\mathrm{NMR}\left(\mathrm{CDCl}_{3}\right): \delta 1.82\left(\mathrm{~s}, 6 \mathrm{H}, \beta-\mathrm{CH}_{3}\right), 2.24\left(\mathrm{~s}, 6 \mathrm{H}, \mathrm{Ar}-\mathrm{CH}_{3}\right), 2.26\left(\mathrm{~s}, 6 \mathrm{H}, \mathrm{Ar}-\mathrm{CH}_{3}\right), 5.32$ $(\mathrm{s}, 1 \mathrm{H}, \gamma-\mathrm{CH}), 7.08-7.15(\mathrm{~s}, 6 \mathrm{H}, \mathrm{Ar}-H) \mathrm{ppm} .{ }^{11} \mathrm{~B} \mathrm{NMR}\left(\mathrm{C}_{6} \mathrm{D}_{6}\right): \delta-43 \mathrm{ppm}$. IR (Nujol): v 2351, 2327, $1949 \mathrm{~cm}^{-1}\left(\mathrm{BH}_{3}, \mathrm{GeH}\right)$.

\subsubsection{Synthesis of $\left[\left\{\mathrm{HC}(\mathrm{CMeNAr})_{2}\right\} \mathrm{GeH}\right]\left(\mathrm{Ar}=2,6-i \mathrm{Pr}_{2} \mathrm{C}_{6} \mathrm{H}_{3}\right)(13)$}

A solution of $\mathrm{PMe}_{3}(2 \mathrm{~mL}, 1.0 \mathrm{M}$ in toluene) was added to a solution of $\mathbf{1 1}(1.05 \mathrm{~g}, 2.0$ $\mathrm{mmol})$ in $n$ hexane $(30 \mathrm{~mL})$ at room temperature and stirred for $12 \mathrm{~h}$. The color turned from pale yellow to orange. After removal of all volatiles the residue was extracted with $n$ hexane (20 mL). Storage of the extract in a $-32{ }^{\circ} \mathrm{C}$ freezer for $24 \mathrm{~h}$ afforded orange crystals of $\mathbf{1 3}$. 
13: Yield: $0.78 \mathrm{~g}(79 \%)$. Mp: 173 - $175{ }^{\circ} \mathrm{C}$. Anal.: calcd for $\mathrm{C}_{29} \mathrm{H}_{42} \mathrm{GeN}_{2}$ (492.10): $\mathrm{C}$, 70.90; H, 8.62; N, 5.70; found: C, 70.5; H, 8.6; N, 5.6. EI-MS: m/e $491\left([\mathrm{M}-\mathrm{H}]^{+}\right),(100$ \%). ${ }^{1} \mathrm{H}$ NMR $\left(\mathrm{C}_{6} \mathrm{D}_{6}\right): \delta 1.15\left(\mathrm{~d}, 6 \mathrm{H}, \mathrm{CH}\left(\mathrm{CH}_{3}\right)_{2}, J=6.9 \mathrm{~Hz}\right), 1.17\left(\mathrm{~d}, 6 \mathrm{H}, \mathrm{CH}\left(\mathrm{CH}_{3}\right)_{2}, J=\right.$ $6.9 \mathrm{~Hz}), 1.27\left(\mathrm{~d}, 6 \mathrm{H}, \mathrm{CH}\left(\mathrm{CH}_{3}\right)_{2}, J=6.9 \mathrm{~Hz}\right), 1.35\left(\mathrm{~d}, 6 \mathrm{H}, \mathrm{CH}\left(\mathrm{CH}_{3}\right)_{2}, J=6.9 \mathrm{~Hz}\right), 1.54(\mathrm{~s}$, $\left.6 \mathrm{H}, \beta-\mathrm{CH}_{3}\right), 3.24-3.42\left(\mathrm{~m}, 2 \mathrm{H}, \mathrm{CH}\left(\mathrm{CH}_{3}\right)_{2}\right), 3.43-3.62\left(\mathrm{~m}, 2 \mathrm{H}, \mathrm{CH}\left(\mathrm{CH}_{3}\right)_{2}\right), 4.92(\mathrm{~s}, 1$ $\mathrm{H}, \gamma-\mathrm{CH}$ ), $7.02-7.15\left(\mathrm{~m}, 6 \mathrm{H}, 2,6-i \mathrm{Pr}_{2} \mathrm{C}_{6} H_{3}\right), 8.08$ (s, $1 \mathrm{H}, \mathrm{Ge} H$ ) ppm. IR (Nujol): v $1726 \mathrm{~cm}^{-1}(\mathrm{GeH})$.

\subsubsection{Synthesis of $\left[\left\{\mathrm{HC}\left(\mathrm{C}\left(\mathrm{CH}_{2}\right) \mathrm{NAr}\right) \mathrm{CMeNAr}\right\} \mathrm{Ge}(\mathrm{H}) \mathrm{BH}_{3}\right] \mathrm{Li}\left(\mathrm{Et}_{2} \mathrm{O}\right)_{3}(\mathrm{Ar}=2,6-$ $\left.i \operatorname{Pr}_{2} \mathrm{C}_{6} \mathrm{H}_{3}\right)$ (14)}

A solution of $t \mathrm{BuLi}(2 \mathrm{~mL}, 1 \mathrm{M}$ in toluene) was added to a solution of $\mathbf{1 1}(1.01 \mathrm{~g}, 2.0$ mmol) in diethyl ether $(30 \mathrm{~mL})$ at $-78{ }^{\circ} \mathrm{C}$ and the reaction mixture was allowed to warm to room temperature. After additional stirring for $3 \mathrm{~h}$ and storage in a $-32{ }^{\circ} \mathrm{C}$ freezer for $2 \mathrm{~d}$ colorless crystals of $\mathbf{1 4}$ were obtained.

14: Yield: $1.04 \mathrm{~g}(71 \%)$. Mp: $138-140{ }^{\circ} \mathrm{C}$. Anal.: calcd for $\mathrm{C}_{41} \mathrm{H}_{73} \mathrm{BGeLiN}_{2} \mathrm{O}_{3}$ (732.35): C, 67.24; H, 10.05; N, 3.82; found: C, 67.3; H, 10.0; N, 4.0. EI-MS: m/e 491 ([M $\left.\left.\mathrm{Li}\left(\mathrm{Et}_{2} \mathrm{O}\right)_{3}-\mathrm{H}\right]^{+}\right)(100 \%) .{ }^{1} \mathrm{H}$ NMR (toluene- $\left.d_{8}\right): \delta-0.65-1.15\left(\mathrm{br}, 3 \mathrm{H}, \mathrm{B} H_{3}\right), 0.79$ (t, 18 $\mathrm{H}, \mathrm{OCH}_{2} \mathrm{Me}$ ), $1.30-1.50\left(\mathrm{~m}, 24 \mathrm{H}, \mathrm{CH}\left(\mathrm{CH}_{3}\right)_{2}\right), 1.70$ (s, $\left.3 \mathrm{H}, \beta-\mathrm{CH}_{3}\right), 2.85$ (q, $12 \mathrm{H}$, $\mathrm{OCH}_{2} \mathrm{CH}_{3}$ ), 3.19 (s, $1 \mathrm{H}, \beta-\mathrm{CH}_{2}$ ), 3.65 (sept, $2 \mathrm{H}, \mathrm{CH}\left(\mathrm{CH}_{3}\right)_{2}, J=7.0 \mathrm{~Hz}$ ), 3.75 (sept, $2 \mathrm{H}$, $\mathrm{CH}\left(\mathrm{CH}_{3}\right)_{2}, J=7.0 \mathrm{~Hz}$ ), 3.92 (s, $\left.1 \mathrm{H}, \beta-\mathrm{CH}_{2}\right), 3.97$ (sept, $\left.2 \mathrm{H}, \mathrm{CH}\left(\mathrm{CH}_{3}\right)_{2}, J=7.0 \mathrm{~Hz}\right), 4.05$ (sept, $2 \mathrm{H}, \mathrm{CH}\left(\mathrm{CH}_{3}\right)_{2}, J=7.0 \mathrm{~Hz}$ ), 5.38 (s, $1 \mathrm{H}, \gamma-\mathrm{CH}$ ), 6.70 (br, $1 \mathrm{H}, \mathrm{GeH}$ ), $7.04-7.10$ (m, $\left.6 \mathrm{H}, 2,6-i \operatorname{Pr}_{2} \mathrm{C}_{6} H_{3}\right) \mathrm{ppm} .{ }^{7} \mathrm{Li} \mathrm{NMR}$ (toluene- $d_{8}$ ): $\delta-1.4 \mathrm{ppm} .{ }^{11} \mathrm{~B}$ NMR (toluene- $d_{8}$ ): $\delta$ $-43.7 \mathrm{ppm}$. 


\subsubsection{Synthesis of $\left[\left\{\mathrm{HC}(\mathrm{CMeNAr})_{2}\right\} \mathrm{Ge}(\mathrm{S}) \mathrm{Cl}\right]\left(\mathrm{Ar}=2,6-i \mathrm{Pr}_{2} \mathrm{C}_{6} \mathrm{H}_{3}\right)(15)$}

A solution of $\mathbf{3}(0.53 \mathrm{~g}, 1.0 \mathrm{mmol})$ in toluene $(20 \mathrm{~mL})$ was added to a stirred suspension of sulfur $(0.03 \mathrm{~g}, 1.0 \mathrm{mmol})$ in toluene $(10 \mathrm{~mL})$. The reaction mixture was stirred at room temperature for 2 days during which time the color changed from yellow to slightly green. Storage of the reaction mixture at $-32{ }^{\circ} \mathrm{C}$ for 3 days afforded greenish crystals of $\mathbf{1 5}$.

15: Yield: $0.49 \mathrm{~g}\left(88 \%\right.$ ). Mp: $225^{\circ} \mathrm{C}$ (dec.). Anal.: calcd for $\mathrm{C}_{29} \mathrm{H}_{41} \mathrm{ClGeN}_{2} \mathrm{~S}$ (557.74): $\mathrm{C}$, 62.45; H, 7.41; N, 5.02; found: C, 62.5; H, 7.5; N, 5.0. EI-MS: $m / e 558\left(\mathrm{M}^{+}\right), 543([\mathrm{M}-$ $\left.\mathrm{Me}^{+}\right)$. ${ }^{1} \mathrm{H} \mathrm{NMR}\left(\mathrm{C}_{6} \mathrm{D}_{6}\right): \delta 0.97\left(\mathrm{~d}, 6 \mathrm{H}, \mathrm{CH}\left(\mathrm{CH}_{3}\right)_{2}, J=6.9 \mathrm{~Hz}\right), 1.13\left(\mathrm{~d}, 6 \mathrm{H}, \mathrm{CH}\left(\mathrm{CH}_{3}\right)_{2}\right.$, $J=6.9 \mathrm{~Hz}), 1.44-1.51\left(\mathrm{~m}, 18 \mathrm{H}, \mathrm{CH}\left(\mathrm{CH}_{3}\right)_{2}, \beta-\mathrm{CH}_{3}\right), 3.22-3.39\left(\mathrm{~m}, 2 \mathrm{H}, \mathrm{CH}\left(\mathrm{CH}_{3}\right)_{2}\right)$, 3.50-3.75 (m, $\left.2 \mathrm{CH}\left(\mathrm{CH}_{3}\right)_{2}\right), 4.96(\mathrm{~s}, 1 \mathrm{H}, \gamma-\mathrm{CH}), 7.08-7.10\left(\mathrm{~m}, 6 \mathrm{H}, 2,6-i \mathrm{Pr}_{2} \mathrm{C}_{6} H_{3}\right)$ ppm.

\subsubsection{Synthesis of $\left[\left\{\mathrm{HC}(\mathrm{CMeNAr})_{2}\right\} \mathrm{Ge}(\mathrm{S}) \mathrm{F}\right]\left(\mathrm{Ar}=2,6-i \mathrm{Pr}_{2} \mathrm{C}_{6} \mathrm{H}_{3}\right)(16)$}

Route (a): A solution of $\mathbf{1 5}(0.56 \mathrm{~g}, 1.0 \mathrm{mmol})$ in dichloromethane $(10 \mathrm{~mL})$ was added to a suspension of $\mathrm{Me}_{3} \mathrm{SnF}(0.18 \mathrm{~g}, 1.0 \mathrm{mmol})$ in dichloromethane $(10 \mathrm{~mL})$. The reaction mixture was stirred for $2 \mathrm{~d}$ at room temperature. After removal of all volatiles the residue was extracted with toluene $(10 \mathrm{~mL})$. Storage of the extract in a $-32{ }^{\circ} \mathrm{C}$ freezer for $24 \mathrm{~h}$ afforded colorless crystals of $\mathbf{1 6}$ in $87 \%$ yield.

Route (b): A solution of $8(0.51 \mathrm{~g}, 1.0 \mathrm{mmol})$ in toluene $(10 \mathrm{~mL})$ was added to a suspension of elemental sulfur $(0.03 \mathrm{~g}, 1.0 \mathrm{mmol})$ in toluene $(10 \mathrm{~mL})$. The reaction mixture was stirred for $2 \mathrm{~d}$. Filtration and storage of the filtrate in $\mathrm{a}-32{ }^{\circ} \mathrm{C}$ freezer for $24 \mathrm{~h}$ afforded crystals of $\mathbf{1 6}$ in $71 \%$ yield.

16: Mp: $247{ }^{\circ} \mathrm{C}$. EI-MS: $m / e 542\left(\mathrm{M}^{+}\right), 527\left([\mathrm{M}-\mathrm{Me}]^{+}\right) .{ }^{1} \mathrm{H}$ NMR $\left(\mathrm{C}_{6} \mathrm{D}_{6}\right): \delta 1.05(\mathrm{~d}, 6$ $\left.\mathrm{H}, \mathrm{CH}\left(\mathrm{CH}_{3}\right)_{2}, J=6.9 \mathrm{~Hz}\right), 1.18\left(\mathrm{~d}, 6 \mathrm{H}, \mathrm{CH}\left(\mathrm{CH}_{3}\right)_{2}, J=6.9 \mathrm{~Hz}\right), 1.42-1.55(\mathrm{~m}, 18 \mathrm{H}, \beta-$ $\left.\mathrm{CH}_{3}, \mathrm{CH}\left(\mathrm{CH}_{3}\right)_{2}\right), 3.05-3.20\left(\mathrm{~m}, 2 \mathrm{H}, \mathrm{CH}\left(\mathrm{CH}_{3}\right)_{2}\right), 3.40-3.55\left(\mathrm{~m}, 2 \mathrm{H}, \mathrm{CH}\left(\mathrm{CH}_{3}\right)_{2}\right), 4.82$ (s, $1 \mathrm{H}, \gamma-\mathrm{CH}), 6.95-7.10\left(\mathrm{~m}, \mathrm{H}, 2,6-i \mathrm{Pr}_{2} \mathrm{C}_{6} H_{3}\right) \mathrm{ppm} .{ }^{19} \mathrm{~F} \mathrm{NMR}\left(\mathrm{C}_{6} \mathrm{D}_{6}\right): \delta 49.2 \mathrm{ppm}$. 


\subsubsection{Synthesis of $\left[\left\{\mathrm{HC}(\mathrm{CMeNAr})_{2}\right\} \mathrm{Ge}(\mathrm{S}) \mathrm{Me}\right]\left(\mathrm{Ar}=2,6-i \operatorname{Pr}_{2} \mathrm{C}_{6} \mathrm{H}_{3}\right)(17)$}

A solution of MeLi (0.70 mL, $1.6 \mathrm{M}$ in ether) was added to a stirred solution of 16 ( $0.56 \mathrm{~g}$, $1.0 \mathrm{mmol})$ in toluene $(20 \mathrm{~mL})$ at $-32{ }^{\circ} \mathrm{C}$. The reaction mixture was allowed to warm to room temperature and was stirred for another $3 \mathrm{~h}$. After filtration, hexane $(10 \mathrm{~mL})$ was added to the filtrate. Keeping the solution at room temperature for 3 days afforded yellow crystals of 17.

17: Yield: $0.42 \mathrm{~g}(78 \%)$. Mp: $192{ }^{\circ} \mathrm{C}$. EI-MS: $m / e 538\left(\mathrm{M}^{+}\right), 523\left([\mathrm{M}-\mathrm{Me}]^{+}\right) .{ }^{1} \mathrm{H} \mathrm{NMR}$ $\left(\mathrm{C}_{6} \mathrm{D}_{6}\right): \delta 0.76\left(\mathrm{~s}, 3 \mathrm{H}, \mathrm{GeCH}_{3}\right), 1.04\left(\mathrm{~d}, 6 \mathrm{H}, \mathrm{CH}\left(\mathrm{CH}_{3}\right)_{2}, J=6.9 \mathrm{~Hz}\right), 1.15(\mathrm{~d}, 6 \mathrm{H}$, $\left.\mathrm{CH}\left(\mathrm{CH}_{3}\right)_{2}, J=6.9 \mathrm{~Hz}\right), 1.22\left(\mathrm{~d}, 6 \mathrm{H}, \mathrm{CH}\left(\mathrm{CH}_{3}\right)_{2}, J=6.9 \mathrm{~Hz}\right), 1.47\left(\mathrm{~s}, 6 \mathrm{H}, \beta-\mathrm{CH}_{3}\right), 1.67$ $\left(\mathrm{d}, 6 \mathrm{H}, \mathrm{CH}\left(\mathrm{CH}_{3}\right)_{2}, J=6.9 \mathrm{~Hz}\right), 2.95-3.05\left(\mathrm{~m}, 2 \mathrm{H}, \mathrm{CH}\left(\mathrm{CH}_{3}\right)_{2}\right), 4.00-4.15(\mathrm{~m}, 2 \mathrm{H}$, $\left.\mathrm{CH}\left(\mathrm{CH}_{3}\right)_{2}\right), 4.84$ (s, $\left.1 \mathrm{H}, \gamma-\mathrm{CH}\right), 6.90-7.10\left(\mathrm{~m}, 6 \mathrm{H}, 2,6-i \mathrm{Pr}_{2} \mathrm{C}_{6} H_{3}\right) \mathrm{ppm}$.

\subsubsection{Synthesis of $\left[\left\{\mathrm{HC}(\mathrm{CMeNAr})_{2}\right\} \mathrm{Ge}(\mathrm{Se}) \mathrm{Cl}\right]\left(\mathrm{Ar}=2,6-i \mathrm{Pr}_{2} \mathrm{C}_{6} \mathrm{H}_{3}\right)(18)$}

A solution of $\mathbf{3}(0.53 \mathrm{~g}, 1.0 \mathrm{mmol})$ in dichloromethane $(10 \mathrm{~mL})$ was added to a suspension of elemental selenium $(0.08 \mathrm{~g}, 1.0 \mathrm{mmol})$ in dichloromethane $(10 \mathrm{~mL})$. The reaction mixture was stirred for $24 \mathrm{~h}$. After filtration a yellow solution was obtained. Concentration to ca. 10 $\mathrm{mL}$ and storage of the yellow solution in $\mathrm{a}-32{ }^{\circ} \mathrm{C}$ freezer for $24 \mathrm{~h}$ afforded yellow crystals of 18.

18: Yield: $0.53 \mathrm{~g}(87 \%)$. Mp: $230{ }^{\circ} \mathrm{C}$ (dec.). Anal.: calcd for $\mathrm{C}_{29} \mathrm{H}_{49} \mathrm{ClGeN}_{2} \mathrm{Se}$ (605.10): $\mathrm{C}$, 57.61; H, 6.83; N, 4.63; found: C, 57.7; H, 7.0; N, 4.5. EI-MS: m/e $605\left(\mathrm{M}^{+}\right), 590([\mathrm{M}-$ $\left.\mathrm{Me}]^{+}\right), 526\left([\mathrm{M}-\mathrm{Se}]^{+}\right) .{ }^{1} \mathrm{H} \mathrm{NMR}\left(\mathrm{C}_{6} \mathrm{D}_{6}\right): \delta 0.98\left(\mathrm{~d}, 6 \mathrm{H}, \mathrm{CH}\left(\mathrm{CH}_{3}\right)_{2}, J=6.9 \mathrm{~Hz}\right), 1.15(\mathrm{~d}$, $\left.6 \mathrm{H}, \mathrm{CH}\left(\mathrm{CH}_{3}\right)_{2}, J=6.9 \mathrm{~Hz}\right), 1.47\left(\mathrm{~d}, 6 \mathrm{H}, \mathrm{CH}\left(\mathrm{CH}_{3}\right)_{2}, J=6.9 \mathrm{~Hz}\right), 1.481\left(\mathrm{~s}, 6 \mathrm{H}, \beta-\mathrm{CH}_{3}\right)$, $1.484\left(\mathrm{~d}, 6 \mathrm{H}, \mathrm{CH}\left(\mathrm{CH}_{3}\right)_{2}, J=6.9 \mathrm{~Hz}\right), 3.25-3.32\left(\mathrm{~m}, 2 \mathrm{H}, \mathrm{CH}\left(\mathrm{CH}_{3}\right)_{2}\right), 3.62-3.70(\mathrm{~m}, 2$ 
$\left.\mathrm{H}, \mathrm{CH}\left(\mathrm{CH}_{3}\right)_{2}\right), 5.00(\mathrm{~s}, 1 \mathrm{H}, \gamma-\mathrm{CH}), 7.08-7.15\left(\mathrm{~m}, 6 \mathrm{H}, 2,6-i \mathrm{Pr}_{2} \mathrm{C}_{6} H_{3}\right)$ ppm. ${ }^{77} \mathrm{Se} \mathrm{NMR}$ $\left(\mathrm{C}_{6} \mathrm{D}_{6}\right): \delta-287.9 \mathrm{ppm}$.

\subsubsection{Synthesis of $\left[\left\{\mathrm{HC}(\mathrm{CMeNAr})_{2}\right\} \mathrm{Ge}(\mathrm{Se}) \mathrm{F}\right]\left(\mathrm{Ar}=2,6-i \mathrm{Pr}_{2} \mathrm{C}_{6} \mathrm{H}_{3}\right)(19)$}

Route (a): A solution of $\mathbf{1 8}(0.61 \mathrm{~g}, 1.0 \mathrm{mmol})$ in dichloromethane $(10 \mathrm{~mL})$ was added to a suspension of $\mathrm{Me}_{3} \mathrm{SnF}(0.18 \mathrm{~g}, 1.0 \mathrm{mmol})$ in dichloromethane $(10 \mathrm{~mL})$. The reaction mixture was stirred for $2 \mathrm{~d}$ at room temperature. After removal of all volatiles the residue was extracted with toluene $(10 \mathrm{~mL})$. Storage of the extract in a $-32{ }^{\circ} \mathrm{C}$ freezer for $24 \mathrm{~h}$ afforded colorless crystals of $\mathbf{1 9}$ (yield $0.524 \mathrm{~g}, 89 \%$ ).

Route (b): A solution of $8(0.51 \mathrm{~g}, 1.0 \mathrm{mmol})$ in toluene $(10 \mathrm{~mL})$ was added to a suspension of elemental selenium $(0.08 \mathrm{~g}, 1.0 \mathrm{mmol})$ in toluene $(10 \mathrm{~mL})$. The reaction mixture was stirred for $2 \mathrm{~d}$. Filtration and storage of the filtrate in a $-32{ }^{\circ} \mathrm{C}$ freezer for $24 \mathrm{~h}$ afforded crystals of $\mathbf{1 9}$ in a $71 \%$ yield.

19: Mp: $266{ }^{\circ} \mathrm{C}$. EI-MS: $m / e 589\left(\mathrm{M}^{+}\right), 574\left([\mathrm{M}-\mathrm{Me}]^{+}\right) .{ }^{1} \mathrm{H}$ NMR $\left(\mathrm{C}_{6} \mathrm{D}_{6}\right): \delta 1.04(\mathrm{~d}, 6 \mathrm{H}$, $\left.\mathrm{CH}\left(\mathrm{CH}_{3}\right)_{2}, J=6.9 \mathrm{~Hz}\right), 1.18\left(\mathrm{~d}, 6 \mathrm{H}, \mathrm{CH}\left(\mathrm{CH}_{3}\right)_{2}, J=6.9 \mathrm{~Hz}\right), 1.42-1.55$ (t, $18 \mathrm{H}, \beta-\mathrm{CH}_{3}$, $\left.\mathrm{CH}\left(\mathrm{CH}_{3}\right)_{2}\right), 3.05-3.20\left(\mathrm{~m}, 2 \mathrm{H}, \mathrm{CH}\left(\mathrm{CH}_{3}\right)_{2}\right), 3.40-3.60$ (m, $\left.2 \mathrm{H}, \mathrm{CH}\left(\mathrm{CH}_{3}\right)_{2}\right), 4.89$ (s, 1 $\mathrm{H}, \gamma-\mathrm{CH}), 7.02-7.10\left(\mathrm{~m}, 6 \mathrm{H}, 2,6-i \mathrm{Pr}_{2} \mathrm{C}_{6} H_{3}\right) \mathrm{ppm} .{ }^{19} \mathrm{~F} \mathrm{NMR}\left(\mathrm{C}_{6} \mathrm{D}_{6}\right): \delta 54.2 \mathrm{ppm} .{ }^{77} \mathrm{Se}$ $\operatorname{NMR}\left(\mathrm{C}_{6} \mathrm{D}_{6}\right): \delta-465.1 \mathrm{ppm}$.

\subsubsection{Synthesis of $\left[\left\{\mathrm{HC}(\mathrm{CMeNAr})_{2}\right\} \mathrm{Ge}(\mathrm{Se}) n \mathrm{Bu}\right]\left(\mathrm{Ar}=2,6-i \mathrm{Pr}_{2} \mathrm{C}_{6} \mathrm{H}_{3}\right)(20)$}

A solution of $n \mathrm{BuLi}(0.65 \mathrm{~mL}, 1.6 \mathrm{M}$ in hexane) was added to a solution of $\mathbf{3}(0.526 \mathrm{~g}, 1.0$ mmol) in toluene $(20 \mathrm{~mL})$ at $-78{ }^{\circ} \mathrm{C}$. The reaction mixture was allowed to warm to room temperature and was stirred for another $2 \mathrm{~h}$. After filtration and the addition of $10 \mathrm{~mL}$ hexane to the orange-red filtrate, standing of the solution at room temperature for $2 \mathrm{~d}$ afforded yellow crystals of $\mathbf{2 0}$. 
20: Yield: 0.38 g (71 \%). Mp: $165-168{ }^{\circ} \mathrm{C}$. Anal.: calcd for $\mathrm{C}_{33} \mathrm{H}_{50} \mathrm{GeN}_{2} \mathrm{Se}$ (626.20): $\mathrm{C}$, 63.28; H, 8.05; N, 4.47; found: C, 63.3; H, 8.1; N, 4.5. EI-MS: m/e $526\left(\mathrm{M}^{+}\right), 491([\mathrm{M}-$ $\left.\mathrm{Se}-n \mathrm{Bu}]^{+}\right) .{ }^{1} \mathrm{H}$ NMR (toluene- $\left.d_{8}\right): \delta 0.55\left(\mathrm{~m}, 3 \mathrm{H},\left(\mathrm{CH}_{2}\right)_{3} \mathrm{CH}_{3}\right), 0.80-1.10(\mathrm{~m}, 6 \mathrm{H}$, $\left.\left(\mathrm{CH}_{2}\right)_{3} \mathrm{CH}_{3}\right), 0.87\left(\mathrm{~d}, 6 \mathrm{H}, \mathrm{CH}\left(\mathrm{CH}_{3}\right)_{2}, J=6.9 \mathrm{~Hz}\right), 1.01\left(\mathrm{~d}, 6 \mathrm{H}, \mathrm{CH}\left(\mathrm{CH}_{3}\right)_{2}, J=6.9 \mathrm{~Hz}\right)$, $1.31\left(\mathrm{~d}, 6 \mathrm{H}, \mathrm{CH}\left(\mathrm{CH}_{3}\right)_{2}, J=6.9 \mathrm{~Hz}\right), 1.53\left(\mathrm{~s}, 6 \mathrm{H}, \beta-\mathrm{CH}_{3}\right), 1.61\left(\mathrm{~d}, 6 \mathrm{H}, \mathrm{CH}\left(\mathrm{CH}_{3}\right)_{2}, J=\right.$ $6.9 \mathrm{~Hz}), 3.20-3.30\left(\mathrm{~m}, 2 \mathrm{H}, \mathrm{CH}\left(\mathrm{CH}_{3}\right)_{2}\right), 4.30-4.40\left(\mathrm{~m}, 2 \mathrm{H}, \mathrm{CH}\left(\mathrm{CH}_{3}\right)_{2}\right), 4.93(\mathrm{~s}, 1 \mathrm{H}, \gamma-$ $\mathrm{CH}$ ), $7.01-7.10\left(\mathrm{~m}, 6 \mathrm{H}, 2,6-i \operatorname{Pr}_{2} \mathrm{C}_{6} H_{3}\right.$ ) ppm. ${ }^{77} \mathrm{Se}$ NMR (toluene- $d_{8}$ ): $\delta-297 \mathrm{ppm}$.

\subsubsection{Synthesis of $\left[\left\{\mathrm{HC}(\mathrm{CMeNAr})_{2}\right\} \mathrm{GeMe}\right]\left(\mathrm{Ar}=2,6-i \mathrm{Pr}_{2} \mathrm{C}_{6} \mathrm{H}_{3}\right)(21)$}

A solution of MeLi (1.4 mL, $1.6 \mathrm{M}$ in diethyl ether, $2.24 \mathrm{mmol}$ ) was added dropwise to a stirred solution of $3(1.1 \mathrm{~g}, 2.0 \mathrm{mmol})$ in diethyl ether $(40 \mathrm{~mL})$ at $-78{ }^{\circ} \mathrm{C}$. The reaction mixture was allowed to warm to room temperature and was stirred for $3 \mathrm{~h}$. After removal of all volatiles, the residue was extracted with $n$ hexane $(30 \mathrm{~mL})$. Storage of the extract in a -32 ${ }^{\circ} \mathrm{C}$ freezer for $3 \mathrm{~d}$ afforded orange-red crystals of $\mathbf{2 1}$.

21: Yield: $0.90 \mathrm{~g}(89 \%)$. Mp: $131-132{ }^{\circ} \mathrm{C}$. Anal.: calcd for $\mathrm{C}_{30} \mathrm{H}_{44} \mathrm{GeN}_{2}$ (506.34): $\mathrm{C}$, 71.31; H, 8.78; N, 5.54; found: C, 71.5; H, 8.8; N, 5.5. EI-MS: m/e (\%) $506\left(\mathrm{M}^{+}, 5\right), 491$ $\left([\mathrm{M}-\mathrm{Me}]^{+}, 100\right) .{ }^{1} \mathrm{H} \mathrm{NMR}\left(\mathrm{C}_{6} \mathrm{D}_{6}\right): \delta 0.64\left(\mathrm{~s}, 3 \mathrm{H}, \mathrm{GeCH}_{3}\right), 1.16\left(\mathrm{~d}, 6 \mathrm{H}, \mathrm{CH}\left(\mathrm{CH}_{3}\right)_{2}, J=\right.$ $6.9 \mathrm{~Hz}), 1.17\left(\mathrm{~d}, 6 \mathrm{H}, \mathrm{CH}\left(\mathrm{CH}_{3}\right)_{2}, J=6.9 \mathrm{~Hz}\right), 1.29\left(\mathrm{~d}, 6 \mathrm{H}, \mathrm{CH}\left(\mathrm{CH}_{3}\right)_{2}, J=6.9 \mathrm{~Hz}\right), 1.38$ $\left(\mathrm{d}, 6 \mathrm{H}, \mathrm{CH}\left(\mathrm{CH}_{3}\right)_{2}, J=6.9 \mathrm{~Hz}\right), 1.55\left(\mathrm{~s}, 6 \mathrm{H}, \beta-\mathrm{CH}_{3}\right), 3.45-3.50\left(\mathrm{~m}, 2 \mathrm{H}, \mathrm{CH}\left(\mathrm{CH}_{3}\right)_{2}\right)$, $3.65-3.73\left(\mathrm{~m}, 2 \mathrm{H}, \mathrm{CH}\left(\mathrm{CH}_{3}\right)_{2}\right), 4.80(\mathrm{~s}, 1 \mathrm{H}, \gamma-\mathrm{CH}), 7.10-7.15\left(\mathrm{~m}, 6 \mathrm{H}, 2,6-i \mathrm{Pr}_{2} \mathrm{C}_{6} H_{3}\right)$ ppm.

\subsubsection{Synthesis of $\left[\left\{\mathrm{HC}(\mathrm{CMeNAr})_{2}\right\} \mathrm{GenBu}\right]\left(\mathrm{Ar}=2,6-i \mathrm{Pr}_{2} \mathrm{C}_{6} \mathrm{H}_{3}\right)(22)$}

Deep red crystals of $\mathbf{2 2}$ can be obtained in the way similarly to that of $\mathbf{2 1}$ in high yield (85\%). 
22: Mp: $152-155^{\circ} \mathrm{C}$. Anal.: calcd for $\mathrm{C}_{33} \mathrm{H}_{50} \mathrm{GeN}_{2}$ (547.32): C, 72.41; H, 9.21; N, 5.12; found: C, 71.5; H, 9.2; N, 5.0. EI-MS: $m / e(\%) 547\left(\mathrm{M}^{+}, 5\right), 491\left([\mathrm{M}-\mathrm{Bu}]^{+}, 100\right) .{ }^{1} \mathrm{H}$ NMR $\left(\mathrm{C}_{6} \mathrm{D}_{6}\right): \delta 0.65\left(\mathrm{t}, 3 \mathrm{H},\left(\mathrm{CH}_{2}\right)_{3} \mathrm{CH}_{3}\right), 0.80-1.05,\left(\mathrm{~m}, 6 \mathrm{H},\left(\mathrm{CH}_{2}\right)_{3} \mathrm{Me}\right), 1.12(\mathrm{~d}, 6 \mathrm{H}$, $\left.\mathrm{CH}\left(\mathrm{CH}_{3}\right)_{2}, J=6.9 \mathrm{~Hz}\right), 1.16\left(\mathrm{~d}, 6 \mathrm{H}, \mathrm{CH}\left(\mathrm{CH}_{3}\right)_{2}, J=6.9 \mathrm{~Hz}\right), 1.35\left(\mathrm{~d}, 6 \mathrm{H}, \mathrm{CH}\left(\mathrm{CH}_{3}\right)_{2}, J=\right.$ $6.9 \mathrm{~Hz}), 1.42\left(\mathrm{~d}, 6 \mathrm{H}, \mathrm{CH}\left(\mathrm{CH}_{3}\right)_{2}, J=6.9 \mathrm{~Hz}\right), 1.52\left(\mathrm{~s}, 6 \mathrm{H}, \beta-\mathrm{CH}_{3}\right), 3.45-3.60(\mathrm{~m}, 2 \mathrm{H}$, $\left.\mathrm{CH}\left(\mathrm{CH}_{3}\right)_{2}\right), 3.65-3.82\left(\mathrm{~m}, 2 \mathrm{H}, \mathrm{CH}\left(\mathrm{CH}_{3}\right)_{2}\right), 4.72(\mathrm{~s}, 1 \mathrm{H}, \gamma-\mathrm{CH}), 7.05-7.15(\mathrm{~m}, 6 \mathrm{H}$, 2,6-i $\left.\mathrm{Pr}_{2} \mathrm{C}_{6} H_{3}\right) \mathrm{ppm}$.

\subsubsection{Synthesis of $\left[\left\{\mathrm{HC}(\mathrm{CMeNAr})_{2}\right\} \mathrm{Ge}(\mathrm{Se}) \mathrm{Me}\right]\left(\mathrm{Ar}=2,6-i \mathrm{Pr}_{2} \mathrm{C}_{6} \mathrm{H}_{3}\right)(23)$}

A solution of $21(0.51 \mathrm{~g}, 1.0 \mathrm{mmol})$ in toluene $(20 \mathrm{~mL})$ was added to a stirred suspension of elemental selenium $(0.08 \mathrm{~g}, 1.0 \mathrm{mmol})$ in toluene $(10 \mathrm{ml})$ at room temperature. The reaction mixture was stirred for $2 \mathrm{~d}$. After filtration a yellow solution was obtained. Concentration to ca. $10 \mathrm{~mL}$ and storage of the yellow solution in a $-32{ }^{\circ} \mathrm{C}$ freezer for $24 \mathrm{~h}$ afforded yellow crystals of $\mathbf{2 3}$.

23: Yield: $0.51 \mathrm{~g}(87 \%)$. Mp: $210-213{ }^{\circ} \mathrm{C}$ (dec.). Anal.: calcd for $\mathrm{C}_{30} \mathrm{H}_{44} \mathrm{GeN}_{2} \mathrm{Se}$ (584.22): C, 61.67; H, 7.58; N, 4.79; found: C, 61.5; H, 7.5; N, 4.8. EI-MS: m/e 584( $\left.\mathrm{M}^{+}\right)$, $569\left([\mathrm{M}-\mathrm{Me}]^{+}\right), 506\left([\mathrm{M}-\mathrm{Se}]^{+}\right) .{ }^{1} \mathrm{H} \mathrm{NMR}\left(\mathrm{C}_{6} \mathrm{D}_{6}\right): \delta 1.06\left(\mathrm{~d}, 6 \mathrm{H}, \mathrm{CH}\left(\mathrm{CH}_{3}\right)_{2}, J=6.9\right.$ $\mathrm{Hz}), 1.09\left(\mathrm{~d}, 6 \mathrm{H}, \mathrm{CH}\left(\mathrm{CH}_{3}\right)_{2}, J=6.9 \mathrm{~Hz}\right), 1.10\left(\mathrm{~s}, 3 \mathrm{H}, \mathrm{GeCH}_{3}\right), 1.25\left(\mathrm{~d}, 6 \mathrm{H}, \mathrm{CH}\left(\mathrm{CH}_{3}\right)_{2}, J\right.$ $=6.9 \mathrm{~Hz}), 1.46\left(\mathrm{~s}, 6 \mathrm{H}, \beta-\mathrm{CH}_{3}\right), 1.63\left(\mathrm{~d}, 6 \mathrm{H}, \mathrm{CH}\left(\mathrm{CH}_{3}\right)_{2}, J=6.9 \mathrm{~Hz}\right), 2.92-3.02(\mathrm{~m}, 2 \mathrm{H}$, $\left.\mathrm{CH}\left(\mathrm{CH}_{3}\right)_{2}\right), 3.80-3.90\left(\mathrm{~m}, 2 \mathrm{H}, \mathrm{CH}\left(\mathrm{CH}_{3}\right)_{2}\right), 4.81(\mathrm{~s}, 1 \mathrm{H}, \gamma-\mathrm{CH}), 7.01-7.15(\mathrm{~m}, 6 \mathrm{H}$, 2,6-i $\left.\operatorname{Pr}_{2} \mathrm{C}_{6} H_{3}\right)$ ppm. ${ }^{77} \mathrm{Se} \mathrm{NMR}\left(\mathrm{C}_{6} \mathrm{D}_{6}\right): \delta-349 \mathrm{ppm}$.

\subsubsection{Synthesis of $\left[\left\{\mathrm{HC}\left(\mathrm{C}\left(\mathrm{CH}_{2}\right) \mathrm{NAr}\right) \mathrm{CMeNAr}\right\} \mathrm{Ge}(\mathrm{Me}) \mathrm{N}(\mathrm{H}) \mathrm{SiMe}_{3}\right](\mathrm{Ar}=2,6-$ $\left.i \operatorname{Pr}_{2} \mathrm{C}_{6} \mathrm{H}_{3}\right)$ (24)}

A solution of $\mathrm{Me}_{3} \mathrm{SiN}_{3}(0.11 \mathrm{~g}, 0.1 \mathrm{mmol})$ in $n$ hexane $(10 \mathrm{~mL})$ was added to a stirred solution of $21(0.51 \mathrm{~g}, 1.0 \mathrm{mmol})$ in $n$ hexane $(20 \mathrm{~mL})$ at room temperature. After the addition 
the reaction mixture was stirred for $12 \mathrm{~h}$ during which time the color changed from orange-red to pale yellow. Concentration to ca. $10 \mathrm{~mL}$ and storage of the solution in a $-32{ }^{\circ} \mathrm{C}$ freezer for $24 \mathrm{~h}$ afforded yellow crystals of $\mathbf{2 4}$.

24: Yield: 0.36 g (61 \%). Mp: $188-191{ }^{\circ} \mathrm{C}$. Anal.: calcd for $\mathrm{C}_{33} \mathrm{H}_{53} \mathrm{GeN}_{3} \mathrm{Si}$ (593.24): $\mathrm{C}$, 66.90; H, 9.02; N, 7.09; found: C, 66.8; H, 9.1; N, 7.1. EI-MS: m/e $593\left(\mathrm{M}^{+}\right), 578([\mathrm{M}-$ $\left.\mathrm{Me}^{+}\right)(100 \%) . \quad{ }^{1} \mathrm{H}$ NMR (toluene- $\left.d_{8}\right): \delta-0.36$ (s, $\left.9 \mathrm{H}, \mathrm{Si}\left(\mathrm{CH}_{3}\right)_{3}\right), 0.25$ (s, $\left.1 \mathrm{H}, \mathrm{NH}\right), 0.79$ $\left(\mathrm{s}, 3 \mathrm{H}, \mathrm{GeCH}_{3}\right), 1.25-1.50\left(\mathrm{~m}, 24 \mathrm{H}, \mathrm{CH}\left(\mathrm{CH}_{3}\right)_{2}\right), 1.58\left(\mathrm{~s}, 3 \mathrm{H}, \beta-\mathrm{CH}_{3}\right), 3.22(\mathrm{~s}, 1 \mathrm{H}, \beta-$ $\mathrm{CH}_{2}$ ), 3.40 (sept, $2 \mathrm{H}, \mathrm{CH}\left(\mathrm{CH}_{3}\right)_{2}, J=7.0 \mathrm{~Hz}$ ), 3.50 (sept, $2 \mathrm{H}, \mathrm{CH}\left(\mathrm{CH}_{3}\right)_{2}, J=7.0 \mathrm{~Hz}$ ), 3.75 (sept, $2 \mathrm{H}, \mathrm{CH}\left(\mathrm{CH}_{3}\right)_{2}, J=7.0 \mathrm{~Hz}$ ), 3.85 (sept, $2 \mathrm{H}, \mathrm{CH}\left(\mathrm{CH}_{3}\right)_{2}, J=7.0 \mathrm{~Hz}$ ), 3.86 (s, 1 $\left.\mathrm{H}, \beta-\mathrm{CH}_{2}\right), 5.25\left(\mathrm{~s}, 1 \mathrm{H}, \gamma-\mathrm{CH}\right.$ ), $7.10-7.20\left(\mathrm{~m}, 6 \mathrm{H}, 2,6-i \mathrm{Pr}_{2} \mathrm{C}_{6} H_{3}\right) \mathrm{ppm} .{ }^{29} \mathrm{Si} \mathrm{NMR}$ (toluene- $d_{8}$ ): $\delta 5.94$ ppm. IR (Nujol): $v 3361 \mathrm{~cm}^{-1}(\mathrm{NH})$.

\subsubsection{Synthesis of $\left[\left\{\mathrm{HC}(\mathrm{CMeNAr})_{2}\right\} \mathrm{GeMe}_{2}\right] \mathrm{I}\left(\mathrm{Ar}=2,6-i \mathrm{Pr}_{2} \mathrm{C}_{6} \mathrm{H}_{3}\right)(25)$}

A solution of MeI $(0.14 \mathrm{~g}, 0.1 \mathrm{mmol})$ in dichloromethane $(10 \mathrm{~mL})$ was added to a stirred solution of $21(0.51 \mathrm{~g}, 1.0 \mathrm{mmol})$ in dichloromethane $(20 \mathrm{~mL})$ at room temperature. After the addition the reaction mixture was stirred for $10 \mathrm{~d}$ during which time the color changed from orange-red to yellow. Removal of the volatiles, washing of the residue with $n$ hexane $(2 \times 5$ $\mathrm{mL}$ ) and drying in vacuum afforded pale yellow powder of $\mathbf{2 5}$.

25: Yield: 0.59 g $(91 \%)$. Mp: 217 - $219^{\circ} \mathrm{C}$. Anal.: calcd for $\mathrm{C}_{31} \mathrm{H}_{47} \mathrm{GeIN}_{2}$ (647.21): $\mathrm{C}$, 57.53; H, 7.32; N, 4.33; found: C, 57.5; H, 7.3; N, 4.4. EI-MS: $m / e(\%) 521\left([\mathrm{M}-\mathrm{I}]^{+}\right.$, 20), $505\left(\left[\mathrm{M}-\mathrm{I}-\mathrm{CH}_{4}\right]^{+}, 100\right) .{ }^{1} \mathrm{H}$ NMR $\left(\mathrm{CD}_{3} \mathrm{CN}\right): \delta 0.83\left(\mathrm{~s}, 6 \mathrm{H}, \mathrm{Ge}\left(\mathrm{CH}_{3}\right)_{2}\right), 1.19(\mathrm{~d}$, $\left.12 \mathrm{H}, \mathrm{CH}\left(\mathrm{CH}_{3}\right)_{2}, J=6.9 \mathrm{~Hz}\right), 1.28\left(\mathrm{~d}, 12 \mathrm{H}, \mathrm{CH}\left(\mathrm{CH}_{3}\right)_{2}, J=6.9 \mathrm{~Hz}\right), 2.02\left(\mathrm{~s}, 6 \mathrm{H}, \beta-\mathrm{CH}_{3}\right)$, $2.80-3.00\left(\mathrm{~m}, 4 \mathrm{H}, \mathrm{CH}\left(\mathrm{CH}_{3}\right)_{2}\right), 5.85(\mathrm{~s}, 1 \mathrm{H}, \gamma-\mathrm{CH}), 7.38-7.50\left(\mathrm{~m}, 6 \mathrm{H}, 2,6-i \mathrm{Pr}_{2} \mathrm{C}_{6} H_{3}\right)$ ppm. 


\subsubsection{Synthesis of $\left[\left\{\mathrm{HC}(\mathrm{CMeNAr})_{2}\right\}_{2} \mathrm{Sn}\right]\left(\mathrm{Ar}=2,6-i \mathrm{Pr}_{2} \mathrm{C}_{6} \mathrm{H}_{3}\right)(26)$}

A solution of $5(1.14 \mathrm{~g}, 2.0 \mathrm{mmol})$ in $n$ hexane $(30 \mathrm{~mL})$ was added to $\mathrm{C}_{8} \mathrm{~K}$ (excess) at room temperature. The reaction mixture was stirred for $3 \mathrm{~d}$. After filtration of residual tin, graphite and potassium, and partial removal ( $c a 15 \mathrm{~mL}$ ) of the solvent from the filtrate, storage of the filtrate in a $-32{ }^{\circ} \mathrm{C}$ freezer for $7 \mathrm{~d}$ afforded colorless crystals of $\mathbf{2 6}$.

26: Yield: $0.19 \mathrm{~g}(10 \%)$. Mp: $232-237{ }^{\circ} \mathrm{C}$. Anal.: calcd for $\mathrm{C}_{58} \mathrm{H}_{82} \mathrm{~N}_{4} \mathrm{Sn}$ (954.97): C, 73.02; H, 8.66; N, 5.87; found: C, 73.0; H, 8.6; N, 6.0. EI-MS: m/e $537[\mathrm{M}-\mathrm{L}]^{+}(\mathrm{L}=$ $\left.\mathrm{HC}(\mathrm{CMeNAr})_{2}\right) . \quad{ }^{1} \mathrm{H} \mathrm{NMR}\left(\mathrm{C}_{6} \mathrm{D}_{6}\right): \delta 0.88-1.58\left(\mathrm{~m}, 60 \mathrm{H}, \beta-\mathrm{CH}_{3}\right.$ and $\left.\mathrm{CH}\left(\mathrm{CH}_{3}\right)_{2}\right), 2.80$ - $3.40\left(\mathrm{~m}, 8 \mathrm{H}, \mathrm{CH}\left(\mathrm{CH}_{3}\right)_{2}\right), 4.25$ (s, $\left.1 \mathrm{H}, \gamma-\mathrm{CH}\right), 4.77$ (s, $\left.1 \mathrm{H}, \gamma-\mathrm{CH}\right), 6.99-7.03$ (m, 12 H, 2,6-i $\left.\operatorname{Pr}_{2} \mathrm{C}_{6} H_{3}\right)$ ppm. ${ }^{119} \mathrm{Sn} \mathrm{NMR}\left(\mathrm{C}_{6} \mathrm{D}_{6}\right): \delta-246 \mathrm{ppm}$.

\subsubsection{Synthesis of $\left[\left\{\mathrm{HC}(\mathrm{CMeNAr})_{2}\right\} \mathrm{Sn} t \mathrm{Bu}\right]\left(\mathrm{Ar}=2,6-i \mathrm{Pr}_{2} \mathrm{C}_{6} \mathrm{H}_{3}\right)(27)$}

A solution of $t \mathrm{BuLi}$ in $n$ hexane $(0.4 \mathrm{~mL}, 1.6 \mathrm{M})$ was added dropwise to a stirred solution of $5(0.35 \mathrm{~g}, 0.62 \mathrm{mmol})$ in $n$ hexane $(20 \mathrm{~mL})$ at $-78{ }^{\circ} \mathrm{C}$. The reaction mixture was allowed to warm to room temperature and was stirred for additional $3 \mathrm{~h}$. The precipitate was filtered and the solvent was partially removed $(\mathrm{ca} 10 \mathrm{~mL})$ from the red filtrate. Storage of the remaining solution in a $-10{ }^{\circ} \mathrm{C}$ freezer for $5 \mathrm{~d}$ afforded red crystals of 27.

27: Yield: $0.32 \mathrm{~g}(85 \%)$. Mp: $188-190{ }^{\circ} \mathrm{C}$. Anal.: calcd for $\mathrm{C}_{33} \mathrm{H}_{50} \mathrm{~N}_{2} \mathrm{Sn}$ (593.47): C, 66.79; H, 8.49; N, 4.72; found: C, 66.6; H, 8.5; N, 4.6. EI-MS: $m / e 537[\mathrm{M}-t \mathrm{Bu}]^{+} .{ }^{1} \mathrm{H}$ NMR $\left(\mathrm{C}_{6} \mathrm{D}_{6}\right): \delta 0.88\left(\mathrm{~s}, 9 \mathrm{H}, \mathrm{C}\left(\mathrm{CH}_{3}\right)_{3}\right), 1.12\left(\mathrm{~d}, 6 \mathrm{H}, \mathrm{CH}\left(\mathrm{CH}_{3}\right)_{2}, J=6.9 \mathrm{~Hz}\right), 1.14(\mathrm{~d}, 6$ $\left.\mathrm{H}, \mathrm{CH}\left(\mathrm{CH}_{3}\right)_{2}, J=6.9 \mathrm{~Hz}\right), 1.32\left(\mathrm{~d}, 6 \mathrm{H}, \mathrm{CH}\left(\mathrm{CH}_{3}\right)_{2}, J=6.9 \mathrm{~Hz}\right), 1.40\left(\mathrm{~d}, 6 \mathrm{H}, \mathrm{CH}\left(\mathrm{CH}_{3}\right)_{2}, J\right.$ $=6.9 \mathrm{~Hz}), 1.61\left(\mathrm{~s}, 6 \mathrm{H}, \beta-\mathrm{CH}_{3}\right), 3.30-3.42\left(\mathrm{~m}, 2 \mathrm{H}, \mathrm{CH}\left(\mathrm{CH}_{3}\right)_{2}\right), 3.72-3.82(\mathrm{~m}, 2 \mathrm{H}$, $\left.\mathrm{C} H\left(\mathrm{CH}_{3}\right)_{2}\right), 4.82(\mathrm{~s}, 1 \mathrm{H}, \gamma-\mathrm{CH}), 6.95-7.11\left(\mathrm{~m}, 6 \mathrm{H}, 2,6-i \mathrm{Pr}_{2} \mathrm{C}_{6} H_{3}\right) \mathrm{ppm} .{ }^{119} \mathrm{Sn} \mathrm{NMR}$ $\left(\mathrm{C}_{6} \mathrm{D}_{6}\right): \delta 259 \mathrm{ppm}$. 


\subsubsection{Synthesis of $\left[\left\{\mathrm{HC}(\mathrm{CMeNAr})_{2}\right\} \mathrm{SnOSO}_{2} \mathrm{CF}_{3}\right]\left(\mathrm{Ar}=2,6-i \mathrm{Pr}_{2} \mathrm{C}_{6} \mathrm{H}_{3}\right)(28)$}

A solution of $5(0.57 \mathrm{~g}, 1.0 \mathrm{mmol})$ in toluene $(20 \mathrm{~mL})$ was added to a stirred suspension of $\mathrm{AgSO}_{3} \mathrm{CF}_{3}(0.24 \mathrm{~g}, 1.0 \mathrm{mmol})$ in toluene $(10 \mathrm{~mL})$ at $-78{ }^{\circ} \mathrm{C}$. The reaction mixture was allowed to warm to room temperature and was stirred for $1 \mathrm{~h}$. The precipitate was filtered and the solvent was partially removed to $c a 15 \mathrm{~mL}$ under reduced pressure from the pale yellow filtrate. Storage of the remaining solution in $\mathrm{a}-10{ }^{\circ} \mathrm{C}$ freezer for $2 \mathrm{~d}$ afforded colorless crystals of $\mathbf{2 8}$ suitable for X-ray diffraction analysis.

28: Yield: $0.55 \mathrm{~g}(80 \%)$. Mp: $150{ }^{\circ} \mathrm{C}$ (dec.). EI-MS: $m / e 686\left(\mathrm{M}^{+}\right) .{ }^{1} \mathrm{H}$ NMR $\left(\mathrm{C}_{6} \mathrm{D}_{6}\right): \delta$ $1.16\left(\mathrm{~d}, 12 \mathrm{H}, \mathrm{CH}\left(\mathrm{CH}_{3}\right)_{2}, J=6.9 \mathrm{~Hz}\right), 1.20\left(\mathrm{~d}, 12 \mathrm{H}, \mathrm{CH}\left(\mathrm{CH}_{3}\right)_{2}, J=6.9 \mathrm{~Hz}\right), 1.62(\mathrm{~s}, 6 \mathrm{H}$, ß-CH$\left.H_{3}\right), 3.21-3.38\left(\mathrm{~m}, 4 \mathrm{H}, \mathrm{CH}\left(\mathrm{CH}_{3}\right)_{2}\right), 5.31$ (s, $\left.1 \mathrm{H}, \gamma-\mathrm{CH}\right), 6.95-7.09$ (m, $6 \mathrm{H}, 2,6-$ $\left.i \operatorname{Pr}_{2} \mathrm{C}_{6} H_{3}\right)$ ppm. ${ }^{19} \mathrm{~F} \mathrm{NMR}\left(\mathrm{C}_{6} \mathrm{D}_{6}\right): \delta 85.28 \mathrm{ppm} .{ }^{119} \mathrm{Sn}$ NMR $\left(\mathrm{C}_{6} \mathrm{D}_{6}\right): \delta-239 \mathrm{ppm}$.

\subsubsection{Synthesis of $\left[\left\{\mathrm{HC}(\mathrm{CMeNAr})_{2}\right\} \mathrm{SnN}_{3}\right]\left(\mathrm{Ar}=2,6-i \mathrm{Pr}_{2} \mathrm{C}_{6} \mathrm{H}_{3}\right)(29)$}

A solution of $5(1.14 \mathrm{~g}, 2.0 \mathrm{mmol})$ in THF $(20 \mathrm{~mL})$ was added to a stirred suspension of $\mathrm{NaN}_{3}(0.13 \mathrm{~g}, 2,0 \mathrm{mmol})$ in $\mathrm{THF}(10 \mathrm{~mL})$ at room temperature. The reaction mixture was stirred for $3 \mathrm{~d}$. After removing the solvent, the residue was extracted with toluene $(20 \mathrm{~mL})$. Storage of the extract in a $-32{ }^{\circ} \mathrm{C}$ freezer for 2 days afforded slightly yellow crystals of 29 .

29: Yield: $1.05 \mathrm{~g}(90 \%)$. Mp: $205-212{ }^{\circ} \mathrm{C}$. Anal.: calcd for $\mathrm{C}_{29} \mathrm{H}_{41} \mathrm{~N}_{5} \mathrm{Sn}$ (578.38): C, 60.22; H, 7.15; N, 12.11: found: C, 60.1; H, 7.0; N, 12.2. EI-MS: m/e (\%) 537 (100) [M $\left.\mathrm{N}_{3}\right]^{+}$. ${ }^{1} \mathrm{H}$ NMR $\left(\mathrm{C}_{6} \mathrm{D}_{6}\right): \delta 1.02\left(\mathrm{~d}, 6 \mathrm{H}, \mathrm{CH}\left(\mathrm{CH}_{3}\right)_{2}, J=6.9 \mathrm{~Hz}\right), 1.15\left(\mathrm{~d}, 6 \mathrm{H}, \mathrm{CH}\left(\mathrm{CH}_{3}\right)_{2}, J\right.$ $=6.9 \mathrm{~Hz}), 1.21\left(\mathrm{~d}, 6 \mathrm{H}, \mathrm{CH}\left(\mathrm{CH}_{3}\right)_{2}, J=6.9 \mathrm{~Hz}\right), 1.49\left(\mathrm{~d}, 6 \mathrm{H}, \mathrm{CH}\left(\mathrm{CH}_{3}\right)_{2}, J=6.9 \mathrm{~Hz}\right), 1.66$ (s, $\left.6 \mathrm{H}, \beta-\mathrm{CH}_{3}\right), 2.90-3.15\left(\mathrm{~m}, 2 \mathrm{H}, \mathrm{CH}\left(\mathrm{CH}_{3}\right)_{2}\right), 3.70-3.82\left(\mathrm{~m}, 2 \mathrm{H}, \mathrm{CH}\left(\mathrm{CH}_{3}\right)_{2}\right), 4.93$ (s, $1 \mathrm{H}, \gamma-\mathrm{CH}), 6.99-7.14\left(\mathrm{~m}, 6 \mathrm{H}, 2,6-i \mathrm{Pr}_{2} \mathrm{C}_{6} H_{3}\right) \mathrm{ppm} .{ }^{119} \mathrm{Sn} \mathrm{NMR}\left(\mathrm{C}_{6} \mathrm{D}_{6}\right): \delta-237 \mathrm{ppm}$. 


\section{Handling and Disposal of Solvents and Residual Wastes}

- The recovered solvents were distilled or condensed into cold traps under vacuum, collected in halogen-free or halogen-containing solvent containers, and stored for disposal.

- Deuterated solvents for NMR were classified into halogen-free and halogen-containing solvents and were disposed as heavy metal wastes and halogen-containing wastes, respectively.

- The heavy metal residues were dissolved in nitric acid and were stored after neutralization in the containers for heavy metal wastes.

- Drying agents such as $\mathrm{KOH}, \mathrm{CaCh}$, and $\mathrm{P}_{4} \mathrm{O}_{10}$ were hydrolyzed and deposited as acid or base wastes.

- Whenever possible, sodium metal used for drying solvents was collected for recycling. ${ }^{55,56}$ The non-reusable sodium metal was carefully hydrolyzed in cold ethanol and poured into the base-bath used for cleaning glassware.

- Ethanol and acetone used for solid $\mathrm{CO}_{2}$ cold-baths were subsequently used for cleaning glassware.

- The acid-bath used for cleaning glassware was neutralized with $\mathrm{Na}_{2} \mathrm{CO}_{3}$ and the resulting $\mathrm{NaCl}$ solution was washed-off in the water drainage.

- The residue of the base bath used for glassware cleaning was poured into the container for base wastes.

Amount of various types of disposable wastes generated during this work:

Metal containing wastes

$10 \mathrm{~L}$

Halogen-containing solvent wastes

Halogen-free solvent wastes

Acid wastes

Base wastes 


\section{Crystal Data and Refinement Details}

Compound

Empirical formula

Formula weight

Temperature

Wavelength

Crystal system

Space group

Unit cell dimensions

Volume

Z

Density (calculated)

Absorption coefficient

$\mathrm{F}(000)$

Crystal size

$\theta$ range for data collection

Index ranges

Reflections collected

Independent reflections

Refinement method

Data / restraints / parameters

Goodness of fit on $\mathrm{F}^{2}$

Final $\mathrm{R}$ indices $[I>2 \sigma(I)]$

$\mathrm{R}$ indices (all data)

Largest diff. peak and hole
3

$\mathrm{C}_{29} \mathrm{H}_{41} \mathrm{ClGeN}_{2}$

525.68

203(2) K

$0.71073 \AA$

Triclinic

$P-1$

$a=8.656(2) \AA \quad \alpha=98.154(15)^{\circ}$

$b=11.571(3) \AA \quad \beta=99.483(14)^{\circ}$

$c=14.946(4) \AA \quad \gamma=104.47(2)^{\circ}$

1403.2(6) $\AA^{3}$

2

$1.244 \mathrm{Mg} / \mathrm{m}^{3}$

$1.205 \mathrm{~mm}^{-1}$

556

$0.8 \times 0.2 \times 0.2 \mathrm{~mm}$

3.66 to $22.52^{\circ}$

$-9 \leq \mathrm{h} \leq 9,-12 \leq \mathrm{k} \leq 12,-10 \leq 1 \leq 16$

3821

$3677[R(\mathrm{int})=0.0399]$

Full-matrix least-squares on $\mathrm{F}^{2}$

3675 / 0 / 308

1.065

$\mathrm{R} 1=0.0380, w \mathrm{R} 2=0.1051$

$\mathrm{R} 1=0.0408, w \mathrm{R} 2=0.1086$

0.537 and -0.540 e. $\AA^{-3}$ 


\section{Compound}

Empirical formula

Formula weight

Temperature

Wavelength

Crystal system

Space group

Unit cell dimensions

Volume

Z

Density (calculated)

Absorption coefficient

$\mathrm{F}(000)$

Crystal size

$\theta$ range for data collection

Index ranges

Reflections collected

Independent reflections

Refinement method

Data / restraints / parameters

Goodness of fit on $\mathrm{F}^{2}$

Final R indices $[I>2 \sigma(I)]$

$\mathrm{R}$ indices (all data)

Largest diff. peak and hole

\section{5}

$\mathrm{C}_{29} \mathrm{H}_{41} \mathrm{ClN}_{2} \mathrm{Sn}$

571.78

200(2) K

$0.71073 \AA$

Triclinic

$P-1$

$a=10.437(2) \AA \quad \alpha=89.80(3)^{\circ}$

$b=12.138(3) \AA \quad \beta=72.327(12)^{\circ}$

$c=12.419(4) \AA \quad \gamma=71.147(14)^{\circ}$

1410.8(6) $\AA^{3}$

2

$1.346 \mathrm{Mg} / \mathrm{m}^{3}$

$1.019 \mathrm{~mm}^{-1}$

592

$1.0 \times 0.4 \times 0.4 \mathrm{~mm}$

3.57 to $25.04^{\circ}$

$-11 \leq \mathrm{h} \leq 2,-14 \leq \mathrm{k} \leq 14,-13 \leq 1 \leq 14$

6610

$4981[\mathrm{R}(\mathrm{int})=0.0572]$

Full-matrix least-squares on $\mathrm{F}^{2}$

4980 / 0 / 308

1.061

$\mathrm{R} 1=0.0354, w \mathrm{R} 2=0.0978$

$\mathrm{R} 1=0.0360, w \mathrm{R} 2=0.0989$

1.697 and -0.921 e. $\AA^{-3}$ 


\section{Compound}

Empirical formula

Formula weight

Temperature

Wavelength

Crystal system

Space group

Unit cell dimensions

Volume

Z

Density (calculated)

Absorption coefficient

$\mathrm{F}(000)$

Crystal size

$\theta$ range for data collection

Index ranges

Reflections collected

Independent reflections

Refinement method

Data / restraints / parameters

Goodness of fit on $\mathrm{F}^{2}$

Final R indices $[I>2 \sigma(I)]$

$\mathrm{R}$ indices (all data)

Largest diff. peak and hole
8

$\mathrm{C}_{29} \mathrm{H}_{41} \mathrm{FGeN}_{2}$

509.23

200(2) K

$0.71073 \AA$

Monoclinic

$P 2{ }_{1} / c$

$a=13.805(3) \AA$

$b=16.060(4) \AA \beta=116.580(15)^{\circ}$.

$c=14.408(3) \AA$

2856.7(10) $\AA^{3}$

4

$1.184 \mathrm{Mg} / \mathrm{m}^{3}$

$1.096 \mathrm{~mm}^{-1}$

1080

$1.10 \times 0.30 \times 0.30 \mathrm{~mm}^{3}$

3.54 to $25.05^{\circ}$.

$-16 \leq \mathrm{h} \leq 16,-14 \leq \mathrm{k} \leq 19,-17 \leq 1 \leq 17$

9557

$5040[\mathrm{R}(\mathrm{int})=0.0201]$

Full-matrix least-squares on $\mathrm{F}^{2}$

$5040 / 0 / 308$

1.051

$\mathrm{R} 1=0.0359, w \mathrm{R} 2=0.0849$

$\mathrm{R} 1=0.0475, w \mathrm{R} 2=0.0917$

0.503 and -0.333 e. $\AA^{-3}$ 
Compound

Empirical formula

Formula weight

Temperature

Wavelength

Crystal system

Space group

Unit cell dimensions

Volume

Z

Density (calculated)

Absorption coefficient

$\mathrm{F}(000)$

Crystal size

$\theta$ range for data collection

Index ranges

Reflections collected

Independent reflections

Refinement method

Data / restraints / parameters

Goodness of fit on $\mathrm{F}^{2}$

Final R indices $[I>2 \sigma(I)]$

$\mathrm{R}$ indices (all data)

Largest diff. peak and hole

\section{1}

$\mathrm{C}_{29} \mathrm{H}_{45} \mathrm{BGeN}_{2}$

505.07

200(2) K

$0.71073 \AA$

Triclinic

$P-1$

$a=10.713(2) \AA \quad \alpha=105.11(3)^{\circ}$.

$b=15.306(3) \AA \quad \beta=101.30(3)^{\circ}$.

$c=20.340(4) \AA \quad \gamma=100.68(3)^{\circ}$.

3057.6(11) $\AA^{3}$

4

$1.097 \mathrm{Mg} / \mathrm{m}^{3}$

$1.019 \mathrm{~mm}^{-1}$

1080

$0.6 \times 0.4 \times 0.2 \mathrm{~mm}^{3}$

3.51 to $25.00^{\circ}$.

$-12 \leq h \leq 11,-16 \leq k \leq 15,-16 \leq l \leq 21$

9237

$8487[\mathrm{R}(\mathrm{int})=0.1173]$

Full-matrix least-squares on $\mathrm{F}^{2}$

8479 / 9 / 621

1.064

$\mathrm{R} 1=0.0640, w \mathrm{R} 2=0.1530$

$\mathrm{R} 1=0.0959, w \mathrm{R} 2=0.1826$

1.188 and -0.897 e. $\AA^{-3}$ 
Compound

Empirical formula

Formula weight

Temperature

Wavelength

Crystal system

Space group

Unit cell dimensions

Volume

Z

Density (calculated)

Absorption coefficient

$\mathrm{F}(000)$

Crystal size

$\theta$ range for data collection

Index ranges

Reflections collected

Independent reflections

Refinement method

Data / restraints / parameters

Goodness of fit on $\mathrm{F}^{2}$

Final R indices $[I>2 \sigma(I)]$

$\mathrm{R}$ indices (all data)

Largest diff. peak and hole
14

$\mathrm{C}_{41} \mathrm{H}_{73} \mathrm{BGeLiN}_{2} \mathrm{O}_{3}$

732.35

200(2) K

$0.71073 \AA$

Monoclinic

$P 2{ }_{1} / n$

$a=11.245(2) \AA$

$b=19.132(5) \AA \beta=92.52(2)^{\circ}$.

$c=21.115(10) \AA$

4538(3) $\AA^{3}$

4

$1.072 \mathrm{Mg} / \mathrm{m}^{3}$

$0.709 \mathrm{~mm}^{-1}$

1588

$1.10 \times 0.80 \times 0.80 \mathrm{~mm}^{3}$

3.52 to $25.04^{\circ}$.

$-13 \leq \mathrm{h} \leq 12,-8 \leq \mathrm{k} \leq 22,-9 \leq 1 \leq 25$

7135

$7100[\mathrm{R}(\mathrm{int})=0.1543]$

Full-matrix least-squares on $\mathrm{F}^{2}$

$7100 / 1 / 481$

1.041

$\mathrm{R} 1=0.0689, w \mathrm{R} 2=0.1705$

$\mathrm{R} 1=0.1106, w \mathrm{R} 2=0.2043$

0.585 and -1.001 e. $\AA^{-3}$ 
Compound

Empirical formula

Formula weight

Temperature

Wavelength

Crystal system

Space group

Unit cell dimensions

Volume

Z

Density (calculated)

Absorption coefficient

$\mathrm{F}(000)$

Crystal size

$\theta$ range for data collection

Index ranges

Reflections collected

Independent reflections

Refinement method

Data / restraints / parameters

Goodness-of-fit on $\mathrm{F}^{2}$

Final R indices $[I>2 \sigma(I)]$

$\mathrm{R}$ indices (all data)

Largest diff. Peak and hole
15

$\mathrm{C}_{29} \mathrm{H}_{41} \mathrm{~N}_{2} \mathrm{GeClS}$

557.74

133(2) K

$0.71073 \AA$

Monoclinic

$P 2{ }_{1} / c$

$a=16.880(3) \AA$

$\mathrm{b}=13.044(3) \AA \beta=108.57(3)^{\circ}$.

$c=13.801(3) \AA$

2880.5(10) $\AA^{3}$

4

$1.286 \mathrm{Mg} / \mathrm{m}^{3}$

$1.248 \mathrm{~mm}^{-1}$

1176

$0.25 \times 0.13 \times 0.13 \mathrm{~mm}^{3}$

2.01 to $27.82^{\circ}$.

$-22 \leq \mathrm{h} \leq 22,-17 \leq \mathrm{k} \leq 15,-17 \leq 1 \leq 18$

42179

$6747[\mathrm{R}(\mathrm{int})=0.0457]$

Full-matrix least-squares on $\mathrm{F}^{2}$

6747 / 120 / 317

1.092

$\mathrm{R} 1=0.0312, w \mathrm{R} 2=0.0699$

$\mathrm{R} 1=0.0369, w \mathrm{R} 2=0.0721$

0.355 and -0.448 e..$^{-3}$ 
Compound

Empirical formula

Formula weight

Temperature

Wavelength

Crystal system

Space group

Unit cell dimensions

Volume

Z

Density (calculated)

Absorption coefficient

$\mathrm{F}(000)$

Crystal size

$\theta$ range for data collection

Index ranges

Reflections collected

Independent reflections

Refinement method

Data / restraints / parameters

Goodness-of-fit on $\mathrm{F}^{2}$

Final R indices $[I>2 \sigma(I)]$

$\mathrm{R}$ indices (all data)

Largest diff. peak and hole
16

$\mathrm{C}_{36} \mathrm{H}_{49} \mathrm{FGeN}_{2} \mathrm{~S}$ incl. toluene

633.42

200(2) K

$0.71073 \AA$

Monoclinic

$P 2{ }_{1} / n$

$a=13.467(2) \AA$

$\mathrm{b}=16.804(3) \AA \beta=92.783(16)^{\circ}$.

$c=15.668(3) \AA$

3541.5(11) $\AA^{3}$

4

$1.188 \mathrm{Mg} / \mathrm{m}^{3}$

$0.954 \mathrm{~mm}^{-1}$

1344

$1.00 \times 0.40 \times 0.40 \mathrm{~mm}^{3}$

3.56 to $25.13^{\circ}$.

$-16 \leq \mathrm{h} \leq 16,-8 \leq \mathrm{k} \leq 20,-18 \leq 1 \leq 18$

9893

$6266[\mathrm{R}(\mathrm{int})=0.0300]$

Full-matrix least-squares on $\mathrm{F}^{2}$

$6266 / 0 / 381$

1.024

$\mathrm{R} 1=0.0469, w \mathrm{R} 2=0.1239$

$\mathrm{R} 1=0.0551, w \mathrm{R} 2=0.1318$

0.821 and -0.736 e. $\AA^{-3}$ 
Compound

Empirical formula

Formula weight

Temperature

Wavelength

Crystal system

Space group

Unit cell dimensions

Volume

Z

Density (calculated)

Absorption coefficient

$\mathrm{F}(000)$

Crystal size

Theta range for data collection

Index ranges

Reflections collected

Independent reflections

Refinement method

Data / restraints / parameters

Goodness-of-fit on $\mathrm{F}^{2}$

Final R indices $[I>2 \sigma(I)]$

$\mathrm{R}$ indices (all data)

Largest diff. peak and hole
17

$\mathrm{C}_{30} \mathrm{H}_{44} \mathrm{~N}_{2} \mathrm{SGe}$

537.32

133(2) K

$0.71073 \AA$

Monoclinic

$P 2{ }_{1} / n$

$a=12.663(3) \AA$

$\mathrm{b}=19.441(4) \AA \beta=117.49(3)^{\circ}$.

$c=13.350(3) \AA$

2915.4(10) $\AA^{3}$

4

$1.224 \mathrm{Mg} / \mathrm{m}^{3}$

$1.142 \mathrm{~mm}^{-1}$

1144

$0.5 \times 0.1 \times 0.1 \mathrm{~mm}^{3}$

2.71 to $27.67^{\circ}$.

$-9 \leq \mathrm{h} \leq 16,-25 \leq \mathrm{k} \leq 25,-17 \leq 1 \leq 17$

32774

$6745[\mathrm{R}(\mathrm{int})=0.0412]$

Full-matrix least-squares on $\mathrm{F}^{2}$

$6745 / 120 / 314$

1.080

$\mathrm{R} 1=0.0373, w \mathrm{R} 2=0.0975$

$\mathrm{R} 1=0.0448, w \mathrm{R} 2=0.1032$

0.953 and -1.063 e. $\AA^{-3}$ 
Compound

Empirical formula

Formula weight

Temperature

Wavelength

Crystal system

Space group

Unit cell dimensions

Volume

Z

Density (calculated)

Absorption coefficient

$\mathrm{F}(000)$

Crystal size

$\theta$ range for data collection

Index ranges

Reflections collected

Independent reflections

Refinement method

Data / restraints / parameters

Goodness-of-fit on $\mathrm{F}^{2}$

Final R indices $[I>2 \sigma(I)]$

$\mathrm{R}$ indices (all data)

Largest diff. peak and hole
18

$\mathrm{C}_{31} \mathrm{H}_{45} \mathrm{Cl}_{5} \mathrm{GeN}_{2} \mathrm{Se}$

774.49

133(2) K

$0.71073 \AA$

Monoclinic

$P 2{ }_{1} / c$

$a=13.176(3) \AA$

$\mathrm{b}=15.269(3) \AA \quad \beta=91.44(3)^{\circ}$.

$c=18.045(4) \AA$

3629.2(13) $\AA^{3}$

4

$1.417 \mathrm{Mg} / \mathrm{m}^{3}$

$2.238 \mathrm{~mm}^{-1}$

1584

$0.50 \times 0.50 \times 0.20 \mathrm{~mm}^{3}$

2.31 to $27.55^{\circ}$.

$-17 \leq \mathrm{h} \leq 17,-14 \leq \mathrm{k} \leq 19,-23 \leq 1 \leq 23$

40850

$8346[\mathrm{R}(\mathrm{int})=0.0522]$

Full-matrix least-squares on $\mathrm{F}^{2}$

8346 / 120 / 371

1.052

$\mathrm{R} 1=0.0365, w \mathrm{R} 2=0.0834$

$\mathrm{R} 1=0.0553, w \mathrm{R} 2=0.0928$

0.609 and -1.073 e. $\AA^{-3}$ 
Compound

Empirical formula

Formula weight

Temperature

Wavelength

Crystal system

Space group

Unit cell dimensions

Volume

Z

Density (calculated)

Absorption coefficient

$\mathrm{F}(000)$

Crystal size

$\theta$ range for data collection

Index ranges

Reflections collected

Independent reflections

Refinement method

Data / restraints / parameters

Goodness-of-fit on $\mathrm{F}^{2}$

Final R indices $[I>2 \sigma(I)]$

$\mathrm{R}$ indices (all data)

Largest diff. peak and hole
20

$\mathrm{C}_{35} \mathrm{H}_{54} \mathrm{Cl}_{0} \mathrm{GeN}_{2} \mathrm{Se}$

654.35

200(2) K

$0.71073 \AA$

Monoclinic

$P 2{ }_{1} / n$

$a=16.714(3) \AA$

$b=10.213(2) \AA \quad \beta=99.00(3)^{\circ}$.

$c=18.801(4) \AA$

3170.1(11) $\AA^{3}$

4

$1.371 \mathrm{Mg} / \mathrm{m}^{3}$

$2.141 \mathrm{~mm}^{-1}$

1376

$1.0 \times 0.6 \times 0.4 \mathrm{~mm}^{3}$

3.55 to $25.01^{\circ}$.

$-19 \leq \mathrm{h} \leq 19,-7 \leq \mathrm{k} \leq 12,-14 \leq 1 \leq 22$

5791

$5569[\mathrm{R}(\mathrm{int})=0.0568]$

Full-matrix least-squares on $\mathrm{F}^{2}$

5569 / 315 / 350

1.110

$\mathrm{R} 1=0.0430, w \mathrm{R} 2=0.1029$

$\mathrm{R} 1=0.0523, w \mathrm{R} 2=0.1091$

0.575 and -1.603 e. $\AA^{-3}$ 
Compound

Empirical formula

Formula weight

Temperature

Wavelength

Crystal system

Space group

Unit cell dimensions

Volume

Z

Density (calculated)

Absorption coefficient

$\mathrm{F}(000)$

Crystal size

$\theta$ range for data collection

Index ranges

Reflections collected

Independent reflections

Refinement method

Data / restraints / parameters

Goodness of fit on $\mathrm{F}^{2}$

Final $\mathrm{R}$ indices $[I>2 \sigma(I)]$

$\mathrm{R}$ indices (all data)

Largest diff. peak and hole

\section{1}

$\mathrm{C}_{30} \mathrm{H}_{44} \mathrm{GeN}_{2}$

505.26

200(2) K

$0.71073 \AA$

Monoclinic

$P 2{ }_{1} / c$

$a=17.230(3) \AA$

$b=13.211(3) \AA \quad \beta=109.011(15)^{\circ}$.

$c=13.3226(19) \AA$

2867.2(9) $\AA^{3}$

4

$1.170 \mathrm{Mg} / \mathrm{m}^{3}$

$1.087 \mathrm{~mm}^{-1}$

1080

$1.00 \times 0.60 \times 0.30 \mathrm{~mm}^{3}$

3.52 to $22.54^{\circ}$.

$-15 \leq \mathrm{h} \leq 18,-14 \leq \mathrm{k} \leq 7,-14 \leq 1 \leq 14$

3944

$3748[\mathrm{R}(\mathrm{int})=0.0637]$

Full-matrix least-squares on $\mathrm{F}^{2}$

3748 / 0 / 309

1.027

$\mathrm{R} 1=0.0388, w \mathrm{R} 2=0.0985$

$\mathrm{R} 1=0.0432, w \mathrm{R} 2=0.1027$

0.601 and -0.519 e. $\AA^{-3}$ 
Compound

Empirical formula

Formula weight

Temperature

Wavelength

Crystal system

Space group

Unit cell dimensions

Volume

Z

Density (calculated)

Absorption coefficient

$\mathrm{F}(000)$

Crystal size

$\theta$ range for data collection

Index ranges

Reflections collected

Independent reflections

Refinement method

Data / restraints / parameters

Goodness-of-fit on $\mathrm{F}^{2}$

Final R indices $[I>2 \sigma(I)]$

$\mathrm{R}$ indices (all data)

Absolute structure parameter

Largest diff. peak and hole

\section{2}

$\mathrm{C}_{33} \mathrm{H}_{50} \mathrm{~N}_{2} \mathrm{Ge}$

547.34

133(2) K

$0.71073 \AA$

Orthorhombic

Fdd2

$\mathrm{a}=22.679(5) \AA$

$\mathrm{b}=63.773(13) \AA$

$c=8.7734(18) \AA$

12689(4) $\AA^{3}$

16

$1.146 \mathrm{Mg} / \mathrm{m}^{3}$

$0.987 \mathrm{~mm}^{-1}$

4704

$0.50 \times 0.38 \times 0.25 \mathrm{~mm}^{3}$

6.17 to $24.95^{\circ}$.

$-26 \leq \mathrm{h} \leq 25,-74 \leq \mathrm{k} \leq 74,-10 \leq 1 \leq 9$

21238

$4647[\mathrm{R}(\mathrm{int})=0.0613]$

Full-matrix least-squares on $\mathrm{F}^{2}$

4647 / 121 / 333

1.092

$\mathrm{R} 1=0.0310, w \mathrm{R} 2=0.0762$

$\mathrm{R} 1=0.0321, w \mathrm{R} 2=0.0766$

$0.047(9)$

0.711 and -0.493 e. $\AA^{-3}$ 
Compound

Empirical formula

Formula weight

Temperature

Wavelength

Crystal system

Space group

Unit cell dimensions

Volume

Z

Density (calculated)

Absorption coefficient

$\mathrm{F}(000)$

Crystal size

$\theta$ range for data collection

Index ranges

Reflections collected

Independent reflections

Refinement method

Data / restraints / parameters

Goodness-of-fit on $\mathrm{F}^{2}$

Final R indices $[I>2 \sigma(I)]$

$\mathrm{R}$ indices (all data)

Largest diff. peak and hole

\section{3}

$\mathrm{C}_{30} \mathrm{H}_{44} \mathrm{GeN}_{2} \mathrm{Se}$

584.22

200(2) K

$0.71073 \AA$

Monoclinic

$\mathrm{P} 2(1) / \mathrm{n}$

$a=13.285(3) \AA$

$\mathrm{b}=17.014(3) \AA \beta=106.01(3)^{\circ}$.

$c=13.752(3) \AA$

2987.7(10) $\AA^{3}$

4

$1.299 \mathrm{Mg} / \mathrm{m}^{3}$

$2.263 \mathrm{~mm}^{-1}$

1216

$0.80 \times 0.80 \times 0.60 \mathrm{~mm}^{3}$

3.78 to $25.04^{\circ}$.

$-15 \leq \mathrm{h} \leq 15,-9 \leq \mathrm{k} \leq 20,-16 \leq 1 \leq 16$

8626

$5267[\mathrm{R}(\mathrm{int})=0.0699]$

Full-matrix least-squares on $\mathrm{F}^{2}$

$5267 / 0 / 318$

1.022

$\mathrm{R} 1=0.0339, w \mathrm{R} 2=0.0877$

$\mathrm{R} 1=0.0384, w \mathrm{R} 2=0.0914$

0.820 and -0.633 e. $\AA^{-3}$ 
Compound

Empirical formula

Formula weight

Temperature

Wavelength

Crystal system

Space group

Unit cell dimensions

Volume

Z

Density (calculated)

Absorption coefficient

$\mathrm{F}(000)$

Crystal size

$\theta$ range for data collection

Index ranges

Reflections collected

Independent reflections

Refinement method

Data / restraints / parameters

Goodness-of-fit on $\mathrm{F}^{2}$

Final R indices $[I>2 \sigma(I)]$

$\mathrm{R}$ indices (all data)

Largest diff. peak and hole

\section{4}

$\mathrm{C}_{33} \mathrm{H}_{53} \mathrm{GeN}_{3} \mathrm{Si}$

592.46

133(2) K

$0.71073 \AA$

Monoclinic

$P 2{ }_{1} / m$

$\mathrm{a}=8.782(2) \AA$

$\mathrm{b}=19.962(4) \AA \quad \beta=114.58(3)^{\circ}$.

$c=10.500(2) \AA$

1673.9(6) $\AA^{3}$

2

$1.175 \mathrm{Mg} / \mathrm{m}^{3}$

$0.975 \mathrm{~mm}^{-1}$

636

$0.25 \times 0.25 \times 0.30 \mathrm{~mm}^{3}$

2.36 to $27.68^{\circ}$.

$-11 \leq \mathrm{h} \leq 7,-26 \leq \mathrm{k} \leq 26,-12 \leq 1 \leq 13$

23957

$4004[\mathrm{R}(\mathrm{int})=0.0586]$

Full-matrix least-squares on $\mathrm{F}^{2}$

4004 / $16 / 213$

1.026

$\mathrm{R} 1=0.0340, w \mathrm{R} 2=0.0860$

$\mathrm{R} 1=0.0392, w \mathrm{R} 2=0.0900$

0.459 and -0.586 e..$^{-3}$ 
Compound

Empirical formula

Formula weight

Temperature

Wavelength

Crystal system

Space group

Unit cell dimensions

Volume

Z

Density (calculated)

Absorption coefficient

$\mathrm{F}(000)$

Crystal size

$\theta$ range for data collection

Index ranges

Reflections collected

Independent reflections

Refinement method

Data / restraints / parameters

Goodness of fit on $\mathrm{F}^{2}$

Final R indices $[I>2 \sigma(I)]$

$\mathrm{R}$ indices (all data)

Largest diff. peak and hole

\section{6}

$\mathrm{C}_{58} \mathrm{H}_{82} \mathrm{~N}_{4} \mathrm{Sn}$

953.97

200(2) K

$0.71073 \AA$

Orthorhombic

$P 2_{1} 2_{1} 2_{1}$

$a=15.8446(12) \AA$

$b=17.024(3) \AA$

$c=22.820(3) \AA$

6156(2) $\AA^{3}$

4

$1.029 \mathrm{Mg} / \mathrm{m}^{3}$

$0.449 \mathrm{~mm}^{-1}$

2032

$0.6 \times 0.5 \times 0.4 \mathrm{~mm}$

3.51 to $25.03^{\circ}$

$-3 \leq \mathrm{h} \leq 18,-20 \leq \mathrm{k} \leq 20,-27 \leq 1 \leq 27$

7396

$6878[R(\mathrm{int})=0.0294]$

Full-matrix least-squares on $\mathrm{F}^{2}$

6872 / 0 / 588

1.143

$\mathrm{R} 1=0.0545, w \mathrm{R} 2=0.1682$

$\mathrm{R} 1=0.0622, w \mathrm{R} 2=0.1834$

1.378 and -0.647 e. $\AA^{-3}$ 
Compound

Empirical formula

Formula weight

Temperature

Wavelength

Crystal system

Space group

Unit cell dimensions

Volume

Z

Density (calculated)

Absorption coefficient

$\mathrm{F}(000)$

Crystal size

$\theta$ range for data collection

Index ranges

Reflections collected

Independent reflections

Refinement method

Data / restraints / parameters

Goodness of fit on $\mathrm{F}^{2}$

Final R indices $[I>2 \sigma(I)]$

$\mathrm{R}$ indices (all data)

Largest diff. peak and hole

\section{8}

$\mathrm{C}_{37} \mathrm{H}_{49} \mathrm{~F}_{3} \mathrm{~N}_{2} \mathrm{O}_{3} \mathrm{SSn}$ incl. toluene

777.53

200(2) K

$0.71073 \AA$

Monoclinic

$P 2{ }_{1} / n$

$a=12.1397(12) \AA$

$b=13.0631(19) \AA \quad \beta=92.597(12)^{\circ}$

$c=23.955(6) \AA$

3795.0(11) $\AA^{3}$

4

$1.361 \mathrm{Mg} / \mathrm{m}^{3}$

$0.779 \mathrm{~mm}^{-1}$

1608

$1.00 \times 0.50 \times 0.20 \mathrm{~mm}$

3.54 to $25.03^{\circ}$

$-14 \leq \mathrm{h} \leq 14,-15 \leq \mathrm{k} \leq 15,-27 \leq 1 \leq 28$

8959

$6687[\mathrm{R}(\mathrm{int})=0.0253]$

Full-matrix least-squares on $\mathrm{F}^{2}$

6687 / 396 / 417

1.050

$\mathrm{R} 1=0.0410, w \mathrm{R} 2=0.1081$

$\mathrm{R} 1=0.0454, w \mathrm{R} 2=0.1132$

1.373 and -1.070 e. $\AA^{-3}$ 


\section{References}

[1] Selected examples: (a) W. P. Neumann, Chem. Rev. 1991, 91, 311. (b) J. T. B. H. Jastrzebski, P. A. Schaaf, J. Boersma, G. Koten, Organometallics 1989, 8, 1373. (c ) C. Drost, P. B. Hitchcock, M. F. Lappert, L. J. Pierssens, J. Chem. Soc., Chem. Commun. 1997, 1141.

[2] (a) 89, J. Jastrzebski, G. Kotn, Adv. Organomet. Chem. 1993, 35, 241. (b) A. G. Brook, M. A. Brook, Adv. Organomet. Chem. 1996, 39, 71. (c) R. Okazaki, R. West, Adv. Organomet. Chem. 1996, 39, 232. (d) M. Weidenbruch, Eur. J. Inorg. Chem. 1999, 373. (e) P. P. Power, Chem. Rev. 1999, 99, 3463. (f) M. F. Lappert, R. S. Rowe, Coord. Chem. Rev. 1990, 100, 267.

[3] (a) M. Rahim, N. J. Taylor, S. Xin, S. Collins, Organometallics 1998, 17, 1315. (b) P. B. Hitchcock, M. F. Lappert, S. Tian, J. Chem. Soc., Dalton Trans. 1997, 1945. (c) P. B. Hitchcock, M. F. Lappert, D. Liu, J. Chem. Soc., Chem. Commun. 1994, 2637. (d) L. W. M. Lee, W. E. Piers, M. R. J. Elsegood, W. Clegg, M. Parvez, Organometallics 1999, 18, 2947.

[4] (a) B. Qian, D. L. Ward, M. R. Smith III, Organometallics 1998, 17, 3070. (b) P. J. Bailey, C. M. E. Dick, S. Fabre, S. Parsons, J. Chem. Soc., Dalton Trans. 2000, 1655. (c ) Gibson, V. C.; Segal, J. A.; White, A. J. P.; Williams, D. J. J. Am. Chem. Soc. 2000, 122, 7120. (d) Radzewich, C. E.; Guzei, I. A.; Jordan, R. F. J. Am. Chem. Soc. 1999, $121,8673$.

[5] C. Cui, H. W. Roesky, H.-G. Schmidt, M. Noltemeyer, H. Hao, F. Cimpoesu, Angew. Chem. 2000, 112, 4444; Angew. Chem., Int. Ed. 2000, 39, 4274.

[6] J. Satgé, M. Massol, P. Rivière, J. Organomet. Chem. 1973, 56, 1.

[7] F. X. Kohl, P. Jutzi, J. Organomet. Chem. 1983, 243, 31.

[8] L. M. Engelhardt, B. S. Jolly, M. F. Lappert, C. L. Raston, A. H. White, J. Chem. Soc., Chem. Commun. 1988, 336. 
[9] (a) E. F. Murphy, R. Murugavel, H. W. Roesky, Chem. Rev. 1997, 97, 342. (b) H. W. Roesky, I. Haiduc, J. Chem. Soc., Dalton Trans. 1999, 2249. (c ) H. W. Roesky, Inorg. Chem. 1999, 38, 5934.

[10] (a) D. J. Brauer, J. Wilke, R. Eujen, J. Organomet. Chem. 1986, 316, 261. (b) E. Lukevics, S. Belyakov, P. Arsenyan, J. Popelis, J. Organomet. Chem. 1997, 549, 163. (c) D. J. Brauer, H. Bürger, R. Eujen, Angew. Chem. 1980, 92, 859; Angew. Chem., Int. Ed. Engl. 1980, 19, 836.

[11] R. W. Chorley, D. Ellis, P. B. Hitchcock, M. F. Lappert, Bull. Soc. Chim. Fr. 1992, 129, 599.

[12] (a) P. Rivière, J. Satgé, A. Castel, H. Normant, C. R. Acad. sci. Paris. 1976, 282, 971. (b) P. Rivière, J. Satgé, A. Castel, H. Normant, C. R. Acad. Sci. Paris. 1977, 284, 395. (c) A. Castel, P. Rivière, J. Satgé, A. Cazes, H. Normant, C. R. Acad. Sci. Paris. 1978, $287,205$.

[13] Selected examples: (a) R. West, J. Organomet. Chem. 1986, 300, 327. (b) R. D. Miller, J. Michl, Chem. Rev. 1989, 89, 1359. (c) M. Birot, J.-P. Pillot, J. Dunoguès, Chem. Rev. 1995, 95, 1443. (d) J. Kouvetakis, A. Haaland, D. J. Shorokhof, H. V. Volden, G. V. Girichev, V. I. Sokolov, S. Schmittinger, P. Matsunaga, J. Am. Chem. Soc. 1998, 120, 6738. (e) P. Braunstein, X. Morise, Chem. Rev. 2000, 100, 3541.

[14] B. E. Eichler, P. P. Power, J. Am. Chem. Soc. 2000, 122, 8785.

[15] (a) M. J. Barrow, E. A. V. Ebsworth, M. M. Harding, D. W. H. Rankin, J. Chem. Soc., Dalton Trans. 1980, 603. (b) C. Brelière, F. Carré, R. J. P. Corriu, G. Royo, Organometallics 1988, 7, 1006. (c) F. Riedmiller, G. L. Wegner, A. Jockisch, H. Schmidbaur, Organometallics 1999, 18, 4317. (d) S. Aldridge, A. J. Downs, Chem. Rev. 2001, 101, 3305. (e) C. Chatgilialoglu, Chem. Rev. 1995, 95, 1229. (f) C. Chatgilialoglu, M. Newcomb, Adv. Organomet. Chem. 1999, 44, 67.

[16] R. West, M. J. Fink, J. Michl, Science 1981, 214, 1343.

[17] A. G. Brook, F. Abdesaken, B. Gutekunst, G. Gutekunst, R. K. Kallury, J. Chem. Soc., Chem. Commun. 1981, 191. 
[18] M. Yoshifuji, I. Shima, N. Inamoto, K. Hirotsu, T. Higuchi, J. Am. Chem. Soc. 1981, $103,4587$.

[19] N. Tokitoh, R. Okazaki, Adv. Organomet. Chem. 2001, 47, 121.

[20] (a) P. Arya, J. Boyer, F. Carré, R. Corriu, G. Lanneau, J. Lapasset, M. Perrot, C. Priou, Angew. Chem. 1989, 101, 1069; Angew. Chem., Int. Ed. Engl. 1989, 28, 1016. (b) H. Suzuki, N. Tokitoh, S. Nagase, R. Okazaki, J. Am. Chem. Soc. 1994, 116, 11578.

[21] (a) M. C. Kuchta, G. Parkin, J. Chem. Soc., Chem. Commun. 1994, 1351. (b) T. Matsumoto, N. Tokitoh, R. Okazaki, Angew. Chem. 1994, 106, 2418; Angew. Chem., Int. Ed. Engl. 1994, 33, 2316. (c) N. Tokitoh, T. Matsumoto, R. Okazaki, J. Am. Chem. Soc. 1997, 119, 2337. (d) S. R. Foley, C. Bensimon, D. S. Richeson, J. Am. Chem. Soc. 1997, 119, 10359. (e) G. Ossig, A. Meller, C. Brönneke, O. Müller, M. Schäfer, R. Herbst-Irmer, Organometallics 1997, 16, 2116. (f) T. Matsumoto, N. Tokitoh, R. Okazaki, J. Am. Chem. Soc. 1999, 121, 8811.

[22] (a) R. Guilard, C. Ratti, J.-M. Barbe, D. Dubois, K. M. Kadish, Inorg. Chem. 1991, 30, 1537. (b) Y. Matsuhashi, N. Tokitoh, R. Okazaki, Organometallics 1993, 12, 2573. (c) M. C. Kuchta, G. Parkin, J. Am. Chem. Soc. 1994, 116, 8372. (d) Y. Zhou, D. S. Richeson, J. Am. Chem. Soc. 1996, 118, 10850. (e) W.-P. Leung, W.-H. Kwok, L. T. C. Law, Z.-Y. Zhou, T. C. W. Mak, J. Chem. Soc., Chem. Commun. 1996, 505. (f) M. Saito, N. Tokitoh, R. Okazaki, J. Am. Chem. Soc. 1997, 119, 11124.

[23] M. Driess, H. Grützmacher, Angew. Chem. 1996, 108, 900; Angew. Chem., Int. Ed. Engl. 1996, 35, 828.

[24] E. J. Bulten, J. G. Noltes, Tetrahedron Lett. 1967, 16, 1443.

[25] P. Jutzi, S. Keitemeyer, B. Neumann, H.-G. Stammler, Organometallics, 1999, 18, 4778.

[26] (a) M. P. Bigwood, P. J. Corvan, J. J. Zuckerman, J. Am. Chem. Soc. 1981, 103, 7643. (b) R. West, Science 1984, 225, 1108. (c) K. M. Baines, W. G. Stibbs, Adv. Organomet. Chem. 1996, 39, 275. (d) P. B. Hitchcock, M. F. Lappert, M. Layh, Inorg. Chim. Acta 1998, 269, 181. (e) A. E. Ayers, D. S. Marynick, H. V. R. Dias, Inorg. Chem. 2000, 39, 4147. 
[27] R. J. Batchelor, J. N. R. Ruddick, J. R. Sams, F. Aubke, Inorg. Chem. 1977, 16, 1414.

[28] P. B. Hitchcock, M. F. Lappert, G. A. Lawless, G. M. Lima, L. J. Pierssens, J.

Organomet. Chem. 2000, 601, 142.

[29] (a) M. Veith, S. Becker, V. Huch, Angew. Chem. 1989, 101, 1287; Angew. Chem., Int. Ed. Engl. 1989, 28, 1237. (b) M. Veith, S. Becker, V. Huch, Angew. Chem. 1990, 102, 186; Angew. Chem., Int. Ed. Engl. 1990, 29, 216.

[30] C. Drost, P. B. Hitchcock, M. F. Lappert, Organometallics 1998, 17, 3838.

[31] (a) A. E. Ayers, T. M. Klapötke, H. V. R. Dias, Inorg. Chem. 2001, 40, 1000. (b) H. V. R. Dias, Z. Wang, J. Am. Chem. Soc. 1997, 119, 4650

[32] (a) C. Heinemann, W. A. Herrmann, W. Thiel, J. Organomet. Chem. 1994, 475, 73.

(b) C. Boehme, G. Frenking, J. Am. Chem. Soc. 1996, 118, 2039.

[33] L. Pu, M. M. Olmstead, P. P. Power, Organometallics 1998, 17, 5602.

[34] M. N. Hansen, K. Niedenzu, J. Serwatowska, J. Serwatowski, K. R. Woodrum, Inorg. Chem. 1991, 30, 866.

[35] (a) A. Akkari, J. J. Byrne, I. Saur, G. Rima, H. Gornitzka, J. Barrau, J. Organomet. Chem. 2001, 622, 190. (b) A. P. Dove, V. C. Gibson, E. L. Marshall, A. J. P. White, D. J. Williams, Chem. Commun. 2001, 283.

[36] P. B. Hitchcock, M. F. Lappert, D. Liu, J. Chem. Soc., Chem. Commun. 1994, 1699. [37] (a) G. M. Begun, A. C. Rutenberg, Inorg. Chem. 1967, 6, 2212. (b) J. C. Evans, J. Chem. Phys. 1959, 30, 934. (c) J. J. Harris, B. Rudner, J. Inorg. Nucl. Chem. 1972, $34,75$.

[38] R. Tacke, J. Heermann, M. Pülm, Z. Naturforsch. 1998, 53b, 535.

[39] (a) J. Barrau, G. Rima, T. El Amraoui, J. Organomet. Chem. 1998, 570, 163. (b) J. Pfeiffer, W. Maringgele, M. Noltemeyer, A. Meller, Chem. Ber. 1989, 122, 245. (c ) M. Veith, A. Rammo, Z. Anorg. Allg. Chem. 1997, 623, 861.

[40] G. Wilkinson, F. G. A. Stone, E. W. Abel, Comprehensive Organometallic Chemistry, 2, 1982, 399.

[41] C. Cui, H. W. Roesky, H. Hao, H.-G. Schmidt, M. Noltemeyer, Angew. Chem. 2000, 112, 1888; Angew. Chem., Int. Ed. 2000, 39, 1815. 
[42] (a) A. J. Arduengo, H. V. R. Dias, J. C. Calabrese, F. Davidson, J. Am. Chem. Soc. 1992, 114, 9724. (b) N. Kuhn, G. Henkel, T. Kratz, J. Kreutzberg, R. Boese, A. H. Maulitz, Chem. Ber. 1993, 126, 2041. (c) N. Kuhn, T. Kratz, D. Bläser, R. Boese, Chem. Ber. 1995, 128, 245. (d) X.-W. Li, J. Su, G. H. Robinson, Chem. Commun. 1996, 2683. (e) N. Metzler, M. Denk, Chem. Commun. 1996, 2657.

[43] A. Castel, P. Riviere, J. Satgé, H. Y. Ko, Organometallics 1990, 9, 205.

[44] M. Veith, A. Detemple, V. Huch, Chem. Ber. 1991, 124, 1135.

[45] E. O. Fischer, E. Moser, Inorg. Synth. 1970, 12.

[46] R. D. Howells, J. D. McCown, Chem. Rev. 1977, 77, 69.

[47] J. S. Thayer, Organomet. Chem. Rev. 1966, 1, 157.

[48] H. V. R. Dias, W. Jin, Inorg. Chem. 2000, 39, 815.

[49] D. F. Shriver, M. A. Drezdzon, The Manipulation of Air-Sensitive Compounds, $2^{\text {nd }}$ Edn., Wiley-Interscience, New York, 1986.

[50] G. M. Sheldrick, Acta Crystallogr. Sec. A 1997, 46, 467.

[51] G. M. Sheldrick, SHELXS-97, University of Göttingen, 1997.

[52] J. Feldman, S. J. McLain, A. Parthasarathy, W. J. Marshall, J. C. Calabrese, S. D. Arthur, Organometallics 1997, 16, 1514.

[53] T. Fjelberg, A. Haaland, B. E. R. Schilling, M. F. Lappert, A. J. Thorne, J. Chem. Soc., Dalton Trans. 1986, 1551.

[54] E. Krause, Ber. Dtsch. Chem. Ges. 1918, 51, 1447.

[55] B. Hübler-Blank, M. Witt, H. W. Roesky, J. Chem. Educ. 1993, 70, 408.

[56] H. W. Roesky, Inorg. Chem. 2001, 40, 6855. 


\section{Lebenslauf}

Yuqiang Ding, geboren am 19. Januar 1967 in Fangcheng, China

Staatsangehörigkeit

Familienstand

Schulausbildung

August 1974 -

Juli 1979

August 1979 -

Juli 1982

August 1982 -

Juli 1985

Hochschulausbildung

$1985-1987$

$1988-1993$

$1993-1996$

$1996-1998$
Chinesisch

verheiratet

Qingwangmiao Grundschule, Fangcheng, China

Dongfeng middle School, Fangcheng, China

Fangcheng High School, Fangcheng, China

Studium Chemie am Fachbereich Chemie der Zhengzhou

University, Zhengzhou, China

Forschungsmitarbeiter am Nanyang Institute of Science and

Technology, Nanyang, China

Studium Chemie am Fachbereich Chemie der Huazhong

University of Science and Technology, Wuhan, China

Forschungsmitarbeiter am Nanyang Institute of Science and

Technology, Nanyang, China 
September 1998 -

Äquivalenzprüfung zum Diplomexamen - Fach Chemie

Dezember 1998

Januar 1999 -

Anfertigung der Dissertation unter Anleitung von Prof. Dr. Dr. h. c.

Juni 2002

mult. H. W. Roesky am Institut für Anorganische Chemie der

Universität Göttingen 